\title{
Application of PV Panels in Large Multi-Story Buildings
}

\section{Feasibility Study}

\author{
A Project Report \\ Presented to the Faculty of Architecture \\ California Polytechnic State University \\ San Luis Obispo \\ In Partial Fulfillment \\ of the Requirements for the Degree \\ Master of Science in Architecture
}

by

Sara Kayal

June 2009 
Copyright (C) 2009 Sara Kayal

ALL RIGHTS RESERVED 


\section{Application of PV Panels in Large Multi-Story Buildings Feasibility Study Sara Kayal}

The awareness of global warming along with an ever increasing demand for a new source of energy has brought a strong interest in harnessing natural resources such as solar energy. This thesis evaluates the viability of applying photovoltaic (PV) panels in high-rise commercial buildings of around 20 stories. Specifically, the thesis is intended to provide a pre-planning tool during the early design stage for architects and designers who are considering the deployment of PV panels in new multi-story construction.

The first three chapters cover a comprehensive literature review and describe several case studies of the application of PV panels in multi-story buildings. The first chapter serves as an introduction to the objectives and rationale of PV panel research. Chapter 2 explains the physics and characteristics of PV panel technology that is applicable to multi-story buildings. Various PV panel types are explored in this chapter and it is suggested that window-based PV panels are the most suitable type for multi-story buildings in which the available roof area is small in area and limited in flexibility due to competition with other uses. Chapter 3 investigates factors that influence the efficiency of PV panels. These factors reduce the efficiency of PV panels to about $10-15 \%$. 
In Chapter 4 a study model is presented to validate the results of the previous chapters and to determine the feasibility of PV panel systems with the aid of computer model analysis and simulation. The study model includes a base case of a 20 -story building that is surrounded by four adjacent buildings, one adjacent to each orientation. Five configurations of the base model with different arrangements of PV panels were analyzed. First, electrical energy of the base case was calculated without applying any PV panels. The second and third configurations include PV panels on all of the available façade areas on a typical summer and winter day, respectively. The fourth and fifth configurations feature PV panels on only the top 10 floors.

The simulation results show that although some savings accrue over a 25 -year lifecycle period, these savings pale in comparison with the initial capital cost associated with the purchase and installation of the PV panels. It was also found that although crystalline silicon panels have a higher initial cost, their superior efficiency and performance present them as better candidates for PV panel applications. In addition, as expected, the south orientation provides potentially the largest amount of electricity production.

In Chapter 5 the simulation results are summarized. The simulation studies address the application of PV panels from three different perspectives, namely: economics; technical feasibility; and, subjective factors. The first four chapters confirm that PV panels, at the current level of technology, are not an efficient and cost effective solution for multi-story buildings. They can satisfy only a very small portion of the iv 
electrical energy demand of the building at a very high initial capital cost. However, some strategies are suggested for mitigating the dual problems of inadequate PV production volume and high initial costs. Subjective factors account for other benefits that are not related to economic considerations. These factors include educational, promotional, and business line promotion benefits that could accrue to the building owner. 


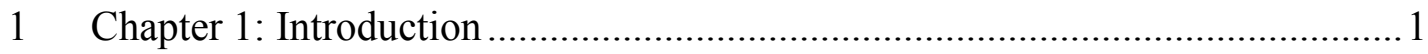

2 Chapter 2: Photovoltaic system principles.......................................................

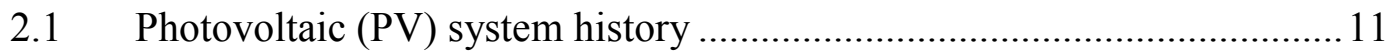

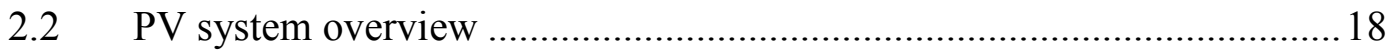

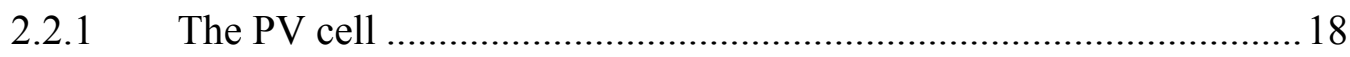

2.2.2 The components of a solar system ..................................................24

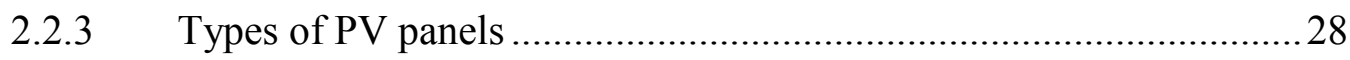

2.2.4 Types of PV panels suitable for multi-story buildings .......................36

3 Chapter 3: Factors that influence the efficiency of BIPV systems ....................52

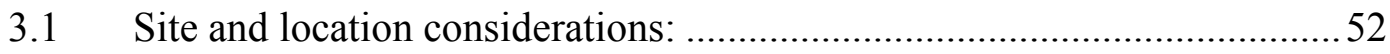

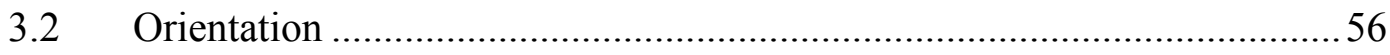

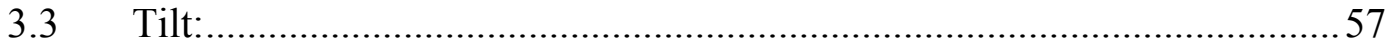

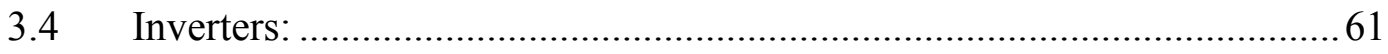

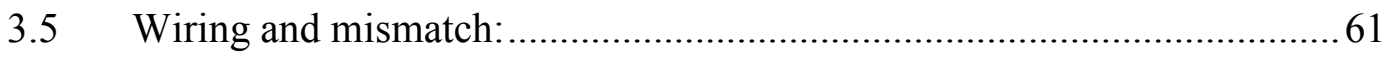

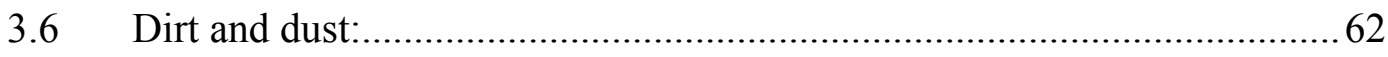

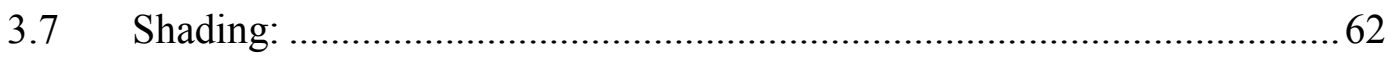

$4 \quad$ Chapter 4: Study model analysis......................................................................65

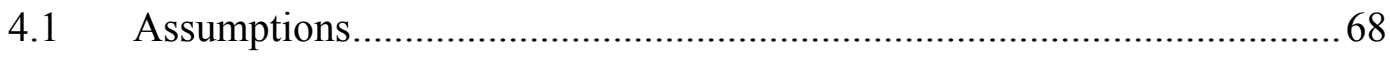




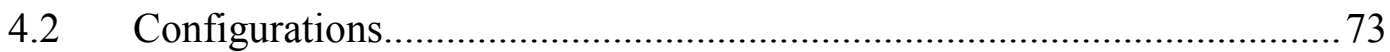

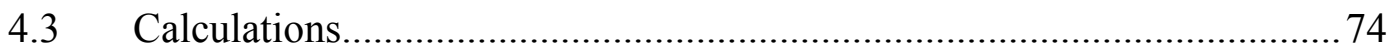

4.3.1 Base case electrical consumption without PV panels ..........................74

4.3.2 PV panel production .....................................................................

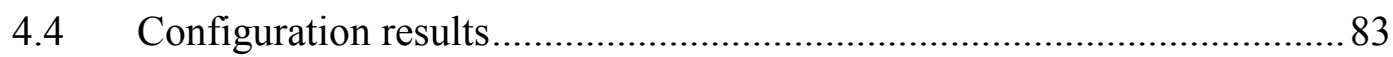

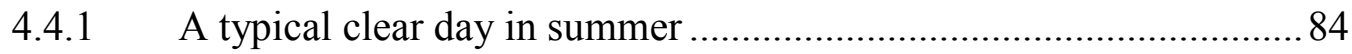

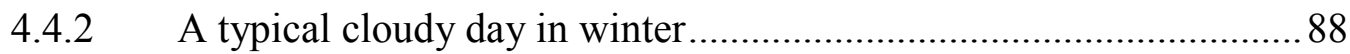

4.4.3 A typical sunny day in summer (upper floors) .................................90

4.4.4 A typical cloudy day in winter (upper floors)....................................92

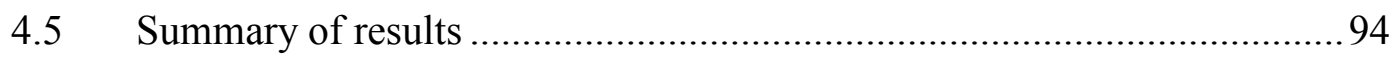

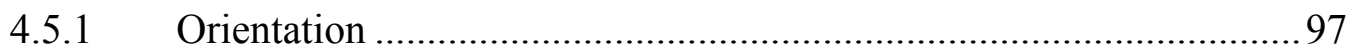

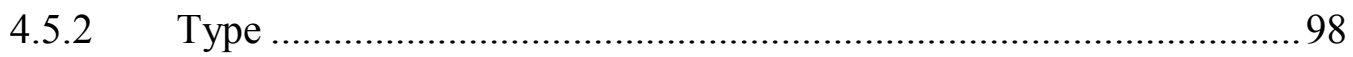

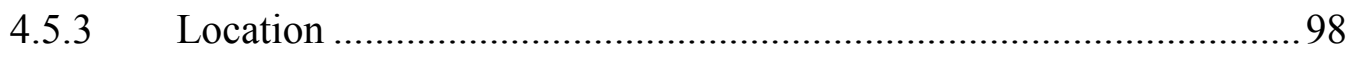

Chapter 5: Conclusions, discussions, and recommendations...................................100

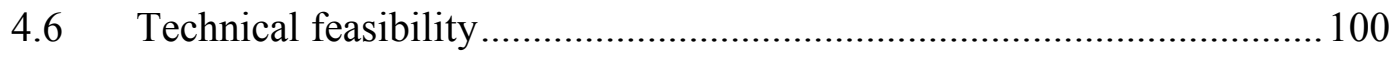

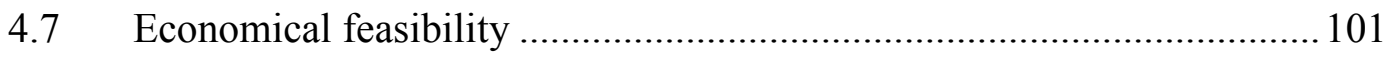

4.8 Subjective (qualitative) feasibility ......................................................... 105

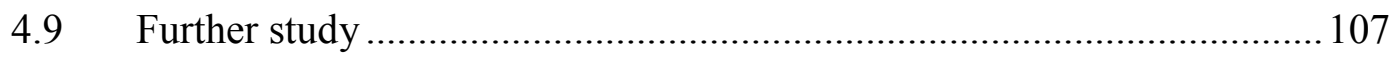

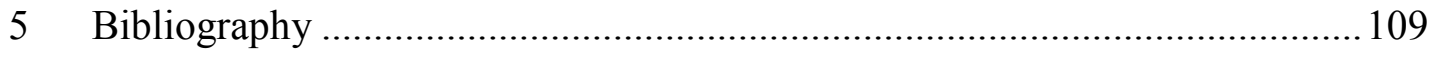




\section{List of Figures}

Figure 1.1: Energy consumption in a typical office building (NREL, 2007) .............3

Figure 1.2: Solar Village, PV systems on roofs in the Netherlands

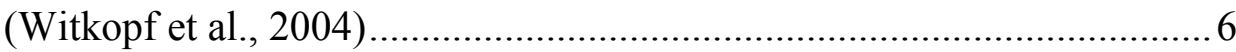

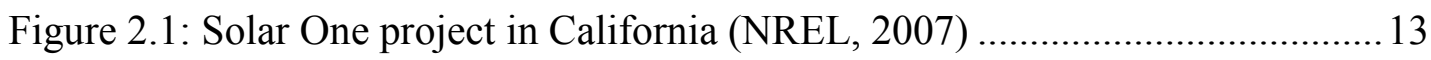

Figure 2.2: Grid-connected photovoltaic system in Kerman, California (NREL,

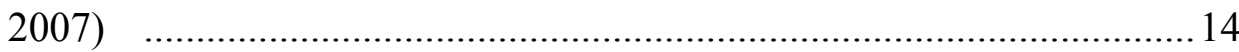

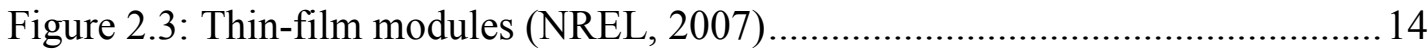

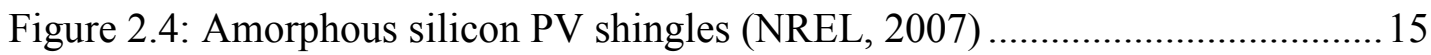

Figure 2.5: 4 Times Square building in New York (NREL, 2001)..........................16

Figure 2.6: Inside a photovoltaic cell (San Diego Regional Renewable Energy

Study Group, 2005) ..................................................................... 19

Figure 2.7: Equivalent circuit of a solar cell (Wikipedia, 2007) ............................20

Figure 2.8: The schematic symbol of a solar cell .................................................20

Figure 2.9: Cells in series form a module. Modules in series-parallel configuration form an array. (San Diego Renewable Energy Study Group, 2005) ........................................................ 21

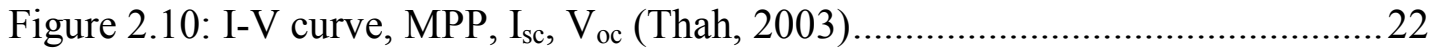

Figure 2.11: Schematic diagram of a complete on-grid PV system (Thah, 2003)....26

Figure 2.12: Summary of different types of PV cells .........................................28

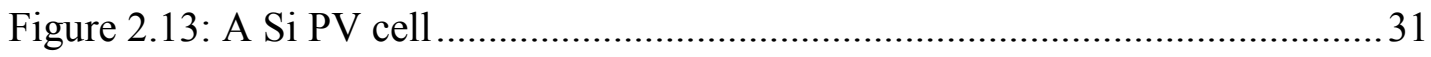

Figure 2.14: Cross-section of an amorphous module with a glass superstrate..........33 
Figure 2.15: Thin-film metal superstrate (San Diego Renewable Energy

Study Group, 2005) ................................................................... 33

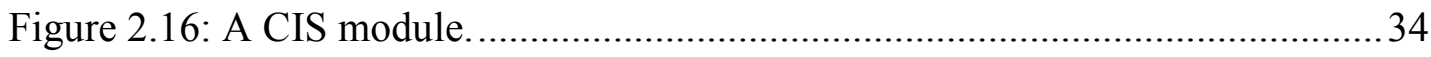

Figure 2.17: Distribution of PV cells and modules in various applications,

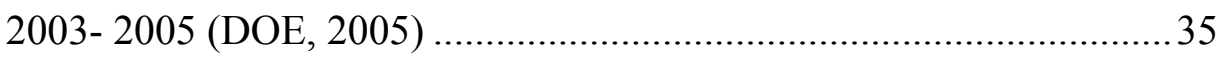

Figure 2.18: A comparison between different types of glass and currently available PV modules (Kiss and Kinkead, 1995) 40

Figure 2.19: Thin film metal substrate applied on the roof and façade systems of a building in the United Kingdom (UK) (Witkopf et al., 2004)......41

Figure 2.20: Atrium with integrated amorphous silicon PV panels in the solar office ofDoxford International Park, in Sunderland, UK. This system produces $73 \mathrm{KW}$. (Thomas, 2000)....................................43

Figure 2.21: The suggested PV glazing amount in the window............................44

Figure 2.22: APS Facility in California, interior space ..................................... 45

Figure 2.23: APS Office Facility in California (Kiss and Kinkead, 1995)...............46

Figure 2.24: 4 Times Square, New York (NREL, 2007) ....................................... 46

Figure 2.25: Inclined PV panels at the University of North Umbria, UK. System was installed in 1994 (Thomas and Fordham, 2001)........................48

Figure 2.26: Samsung commercial office building in Seoul, Korea. A grid-connected system with $40 \mathrm{KW}$ power is integrated in fixed sunshades of the roof (PV Database, 2007). .49

Figure 2.27: Fixed sunshades in the SUVA building. A commercial office building in Switzerland, built in 1993 (Witkopf et al., 2004). .50 
Figure 2.28: Solar wings in an office building in Switzerland with fixed BIPV louvers (PV Database, 2007) 50

Figure 2.29: Moveable sunshades in a commercial office building, in Switzerland (Thomas and Fordham, 2001) .51

Figure 3.1: Typical I-V characteristics of a crystalline PV cell at different temperature (Shenck, 2005) 53

Figure 3.2: I-V characteristics at varied solar intensities (Shenck, 2005) 54

Figure 3.3: PV cell efficiency $(\eta)$ over the normalized range of insolation 55

Figure 4.1: The top view of the study model .66

Figure 4.2: Isometric view of the study model (adjacent buildings are identified) ...67

Figure 4.3: Isometric view of the study model (the tree is located on the south side, the building is oriented north-south)

Figure 4.5: PV production variation for four different orientations (PV panels are crystalline silicon, and they were placed on floors 2 through 11 and 11 through 20). .96

Figure 4.6: Average PV production variation for the entire building, for four orientations, on a clear day in summer and winter 97

Figure 4.7: PV reduction in electricity cost 98 


\section{List of Tables}

Table 2.1: A comparison between different types of PV panels.............................42

Table 3.1: New York City daily clear sky insolation.............................................56

Table 3.2: New York City, NY: Latitude $40.78^{\circ} \mathrm{N}$, south orientation, average

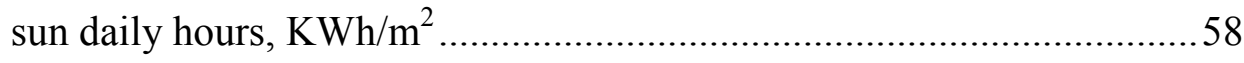

Table 3.3: Insolation in Sacramento, CA (Latitude 37 degrees).............................6 60

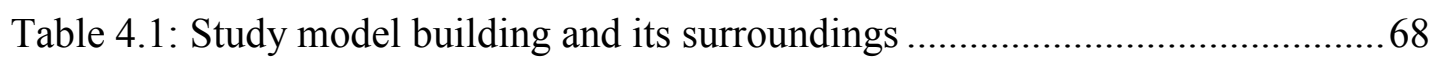

Table 4.2: Hourly electrical consumption on a typical clear summer day...............75

Table 4.3: Hourly electrical consumption on a typical cloudy winter day ..............76

Table 4.4 Cost of components in a $1 \mathrm{KW}$ crystalline PV system: ..........................81

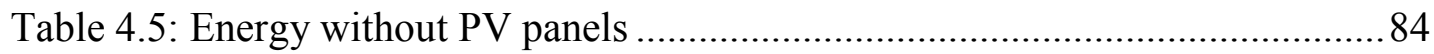

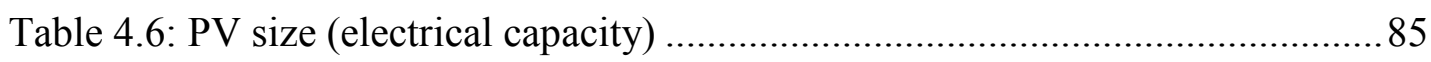

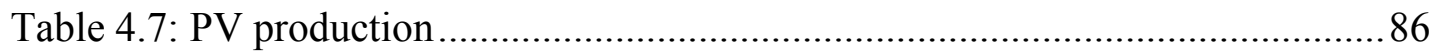

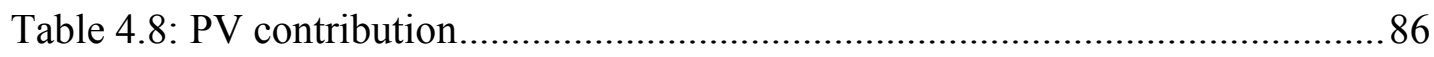

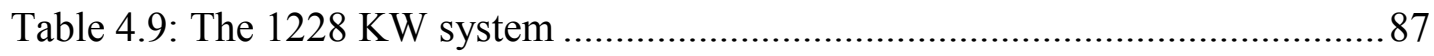

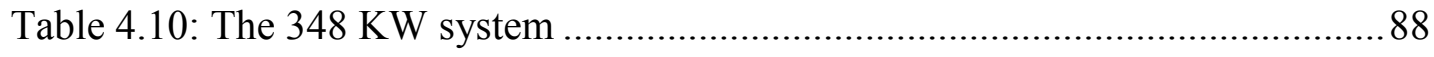

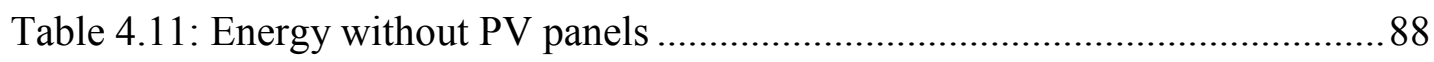

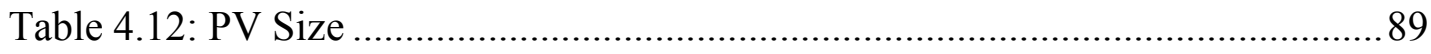

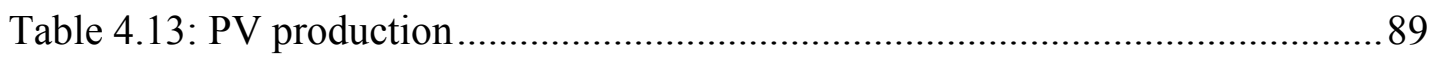

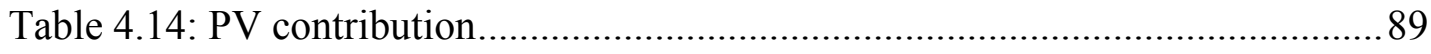

Table 4.15: LCC analysis for the 25-year-lifetime $1228 \mathrm{KW}$ system......................90 
Table 4.16: LCC analysis for the 25-year-lifetime 348 KW system....................... 90

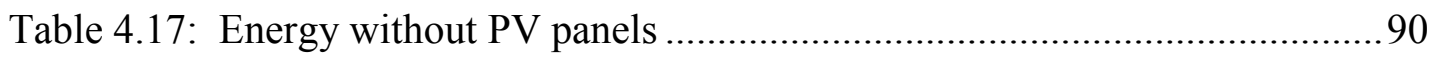

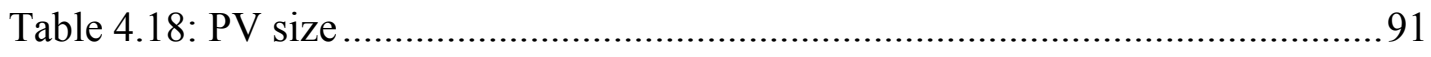

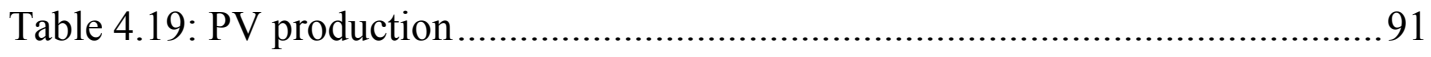

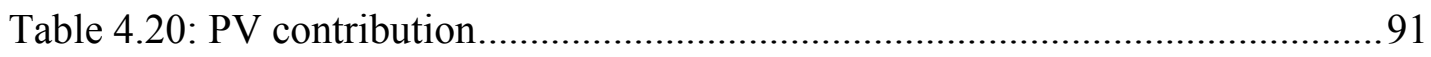

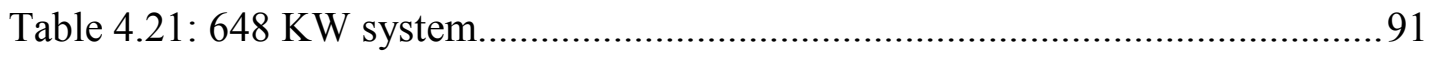

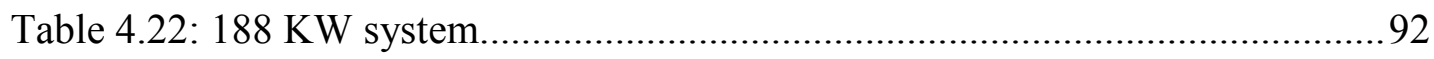

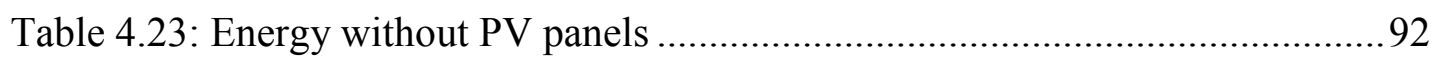

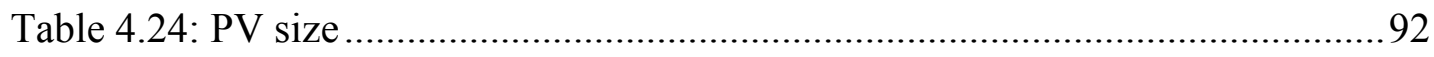

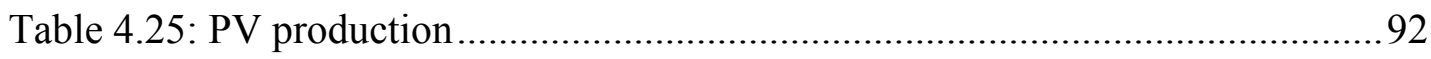

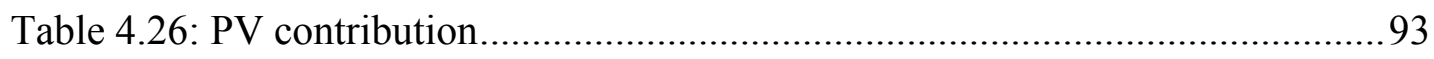

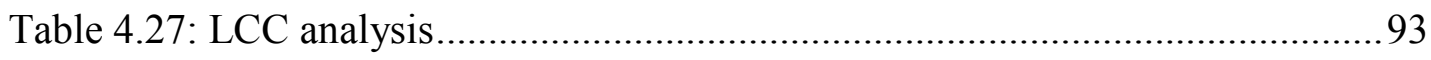

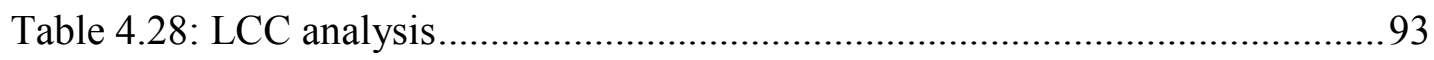

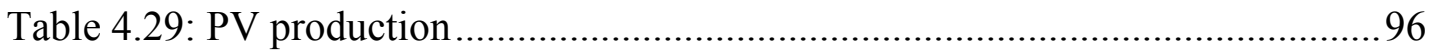




\section{List of Equations}

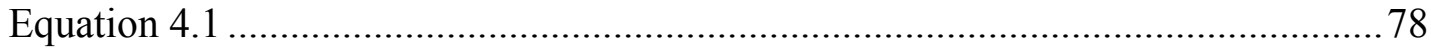

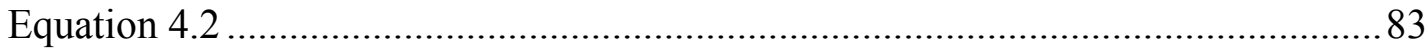

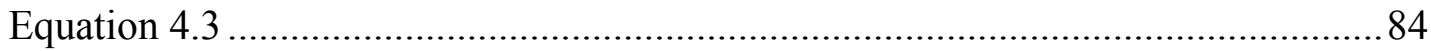

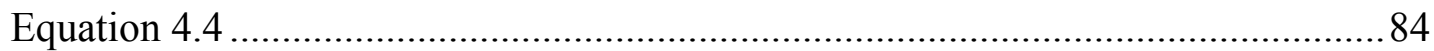

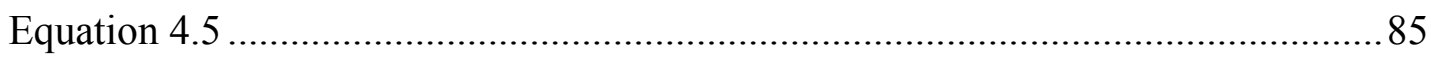

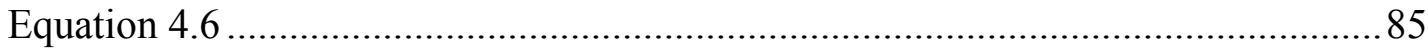

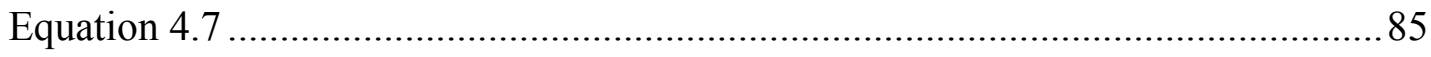




\section{Chapter 1: Introduction}

Since the energy crisis in the 1970s the United States of America (US) has become increasingly concerned about energy resources. By the start of the 1970s, the environmental movement had gained significant momentum and the US Earth Day received the focused attention of millions on April 22, 1970. It was about this time that the movement towards renewable energy was initiated and the importance of funding for research and experimentation became clear. There were several activities initiated in response to the energy crisis. For example, tax inducements were introduced under the Carter administration. More awareness and exploration of alternatives were suggested such as solar energy, wind power, tidal power, ocean thermal conversion, biomass, geothermal energy, conversion of coal into gas, extraction of oil from tar sands, and efforts of tertiary recovery from oil deposits. Debates grew over the technical feasibility and economic viability of these new alternative energy sources. Numerous programs, clubs and regulations were initiated to conserve energy resources. For example, the US Department of Energy (DOE) was directed to lead federal agencies in a strong effort to meet the government's energy-efficiency goals (Kiss and Kinkead, 1995).

Over the past several years, investors have been pouring money into renewable energy, hoping that these investments will ultimately provide a cheaper and more efficient source of energy than the current smorgasbord of fossil fuel alternatives. These initiatives have been promoted by the public fear of another nuclear power 
plant disaster, its hazardous waste and the pollution produced by fossil fuels. As fossil fuels are consumed to meet human needs, they also pollute the air and water, deface the landscape and destroy the ecological systems. This results in undesired sequences such as greenhouse gas emission, ozone depletion, and acid rain that endanger human beings and all living creatures. Based on all of these issues, the need for clean, reliable, abundant, and affordable energy has become evident.

Furthermore, conventional sources of energy are not everlasting and will be depleted in the near future. Looking at this matter economically, residential energy consumption across the US was about 756,000 trillion calorie ${ }^{1}$ in 2003 for fossil fuels (NREL, 2007). This figure varies in the commercial sector. For example, a survey performed by DOE in 2003, including 824 office buildings across the US, recorded a consumption of 832,608 trillion calorie ${ }^{2}$ (i.e. 285,768 trillion calorie in major fuel and 546,840 trillion calorie in electricity) over a period of 12 months. In addition, analysis shows that an office building consumes approximately 21.7 million watts per square meter. Figure 1.1 shows the distribution of annual energy consumption of an office building.

${ }^{1}$ Equals to 3,000 trillion BTU.

2 Equals to 3,304 trillion BTU. 


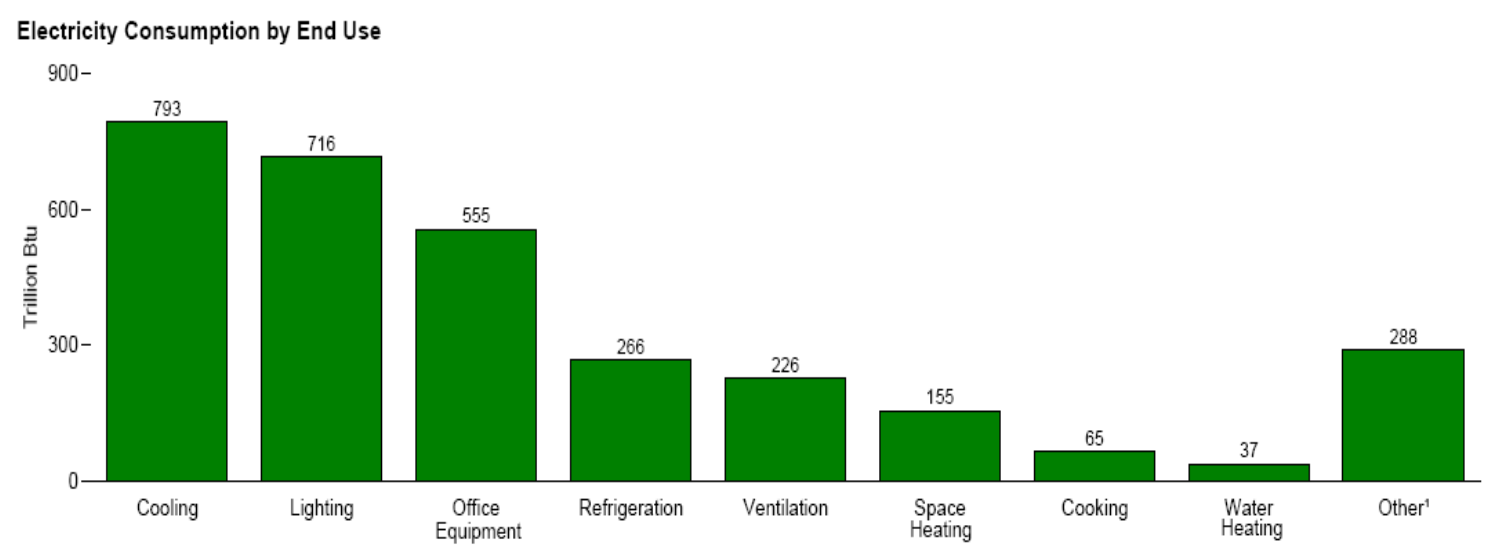

Figure 1.1: Energy consumption in a typical office building (NREL, 2007)

As shown in Figure 1.1 cooling, lighting, and office equipment account for the major part of the electrical energy consumption. High electrical consumption becomes more of an issue in multi-story buildings. The unique characteristic of this building type is its large volume and the relatively small area of external building skin. These characteristics result in an occupancy dominated energy load. In order to supply significant amounts of energy to meet all types of buildings demand with the least impact on the environment and avoiding the drawbacks of fossil fuels other alternatives such as solar energy are suggested. Solar energy appears to offer several benefits, as follows:

- Solar energy is clean and safe compared to the majority of fossil fuels. It does not pollute the air or produce greenhouse gases. Also in its production there is no concern about flammable gases or dangerous waste such as nuclear energy (NREL, 2007).

- It will not be depleted the same as fossil fuels. 
- Solar energy is popular and well-known among the majority of people. Based on several surveys about where the US should obtain its energy in the future, solar energy is often preferred. Thus, despite its drawbacks of intermittency, higher cost and unreliability solar energy remains for many the "holy grail," holding out the vision that sometime in the future all of nation's energy needs can be obtained from the sun (NREL, 2007).

In order to satisfy energy needs with solar energy, it needs to be converted to more useable forms such as heat or electricity. This conversion is accomplished through two common solar solutions: active heating and cooling and photovoltaic (PV) systems. Active heating and cooling systems deploy solar panels on the roof of a building, where either water or air is directly heated by the sun and mechanically transported with pumps or fans. PV panels are semiconductor devices that convert direct or diffused solar radiation into electricity (Budiman, 1988).

Nevertheless, there have been some problematic issues with solar energy applications; energy is not available at all times of the day, in fact it is mostly needed at the time it usually does not exist. The need to store this energy for lighting and heating becomes critical. Energy storage in active heating and cooling systems requires a large area, which is not available in the majority of buildings especially in multi-story buildings. However, PV panels as an option can be connected to utility systems; so that at the time solar energy is not available utility systems can provide the electrical energy demanded by the building. Thus grid-connection PV systems in multi-story buildings have two advantages: first they reduce the need for additional 
space for storage and second, the entire energy demand of the building can be satisfied by the utility at the time when the PV systems are not able to provide sufficient energy. This makes PV systems a more useful tool in areas with space restrictions.

Photovoltaic technology makes use of the abundant energy of the sun and converts it into electrical energy with little impact on the environment. It is commonly accepted that PV systems are useful in small buildings and in applications in which there is not that much electrical power required. A variety of successful cases can be found around the world where PV panels on the roof were able to supply the electrical load of the building. For example, Park Mount housing in Belfast, Northern Ireland, consists of 60 apartments that are equipped with PV panels (Thomas, 2001). Another example is a project called Solar Village in Amersfoort in the Netherlands with more than 500 houses in this project that are using PV panels on the roof (Witkopf et al., 2004). Constant monitoring of this project by professionals and tenants proved the success of this project from the completion of the project (1999) till the present time. 

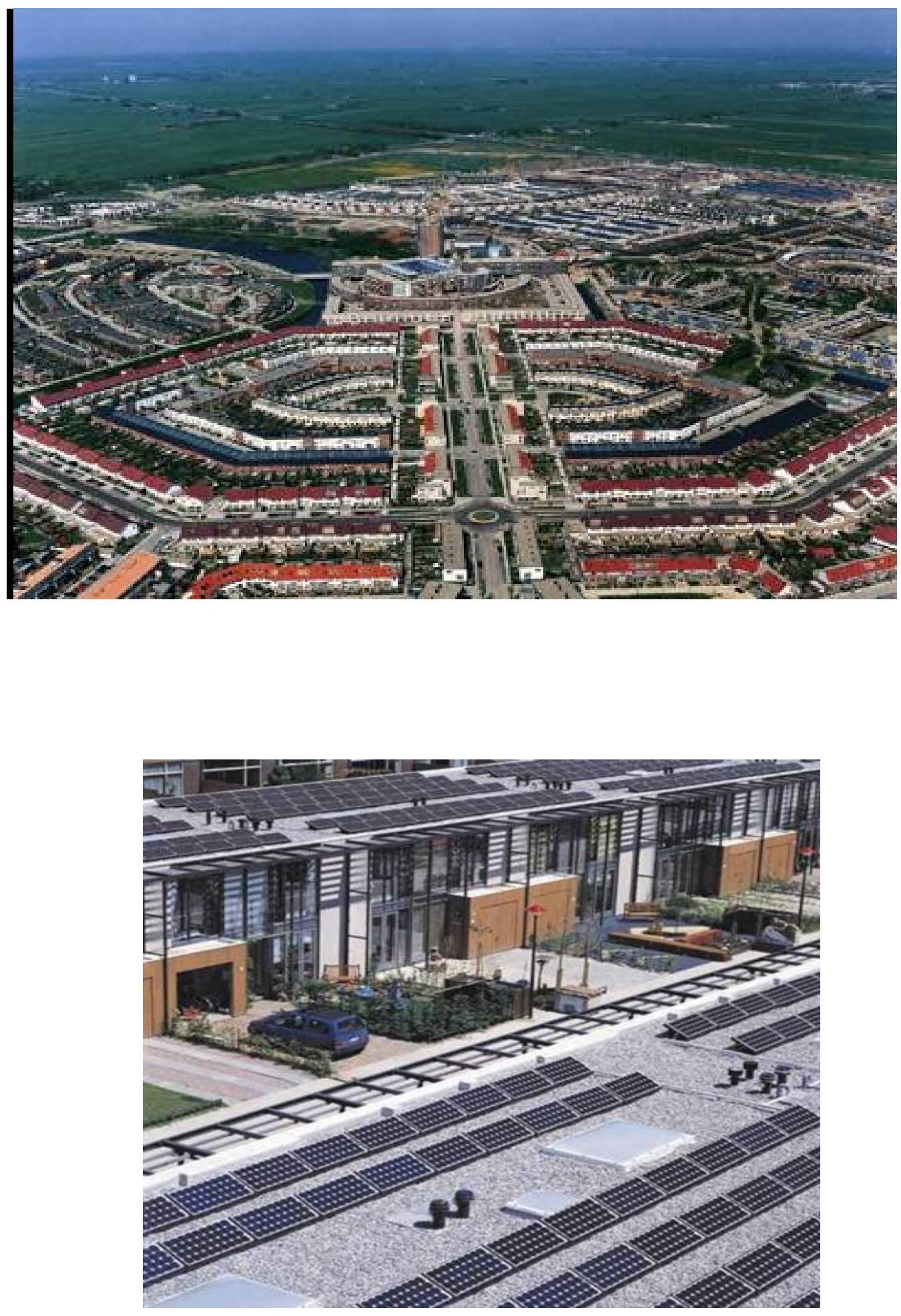

Figure 1.2: Solar Village, PV systems on roofs in the Netherlands (Witkopf et al., 2004) 
However, there appears to be a barrier in multi-story buildings. There is not enough roof area in these types of buildings to produce the energy required. The purpose of this research study is to address this issue, namely the feasibility of PV systems in multi-story buildings. The main objective is to present the concepts, applications and status of PV panels in multi-story buildings of at least 20-story height. Only commercial buildings are considered in this thesis because the majority of multistory buildings are commercial buildings and in particular, commercial office buildings have a major impact on the environment because of their pervasiveness. Commercial office buildings in the US consume about one-half of the nation's electrical supply (DOE, 2005). In the decade of the 1980s, approximately 0.5 billion square meter ${ }^{1}$ of office space were constructed in this country. Tenants who lease space in these buildings mostly represents a vital sector of the economy, employing approximately $27 \%$ of the work force (Statistical Abstract of US, 2003). Furthermore, with the well documented economic and population growth in Asia, the modern high-rise office building is becoming a global reality.

In the relatively few cases of multi-story office buildings that have been fitted with PV panels, the latter have been integrated into the building envelope due to space and architectural limitations. This method is called Building-Integrated Photovoltaic (BIPV) systems. For example, BIPV semi-transparent windows operate the same as normal windows and also provide electricity for the building. These solar systems are thus multifunctional construction elements (Solomon, 2007). Generally, in BIPV systems individual solar cells are electrically connected in a parallel or series

\footnotetext{
${ }^{1} 5.3$ billion square feet
} 
configuration to form a module. Modules are strung together in an electrical series with cables to form a PV array (Messenger, 2004). Direct or even diffused sunlight shining on the solar cells stimulates the electrons and this movement induces a photoelectric effect, generating unregulated direct current (DC) electric power. DC power can be used directly, stored in a battery system, or fed into an inverter that transforms and synchronizes the power into alternating current (AC) electricity. The electricity can be used in the building and the surplus of generated electricity will be exported to a utility company through a grid connection (Thah, 2003).

Different kinds of BIPV systems are commercially available. Generally they fall into three main categories:

\section{Facade systems}

\section{Roof systems}

\section{Sunshade systems}

Facade systems include curtain wall products, spandrel panels, and glazing. Roof systems include tiles, shingles and standing seam products. Sunshade systems include sunscreens, fixed and movable sunshades and rain screens (Kiss and Kinkead, 1995).

BIPV appears to be the most advantageous method of installing renewable energy systems in multi-story buildings in urban areas where undeveloped land is both scarce and costly (Witkopf et al., 2004). The fundamental first step in any BIPV 
application is to optimize energy efficiency within the building's energy demand. This aim is partially reached by improving the thermal insulation of the building envelope to reduce thermal transmission. Windows and facade shelves can be planned to increase day-lighting opportunities in interior spaces. PV awnings can be designed to reduce unwanted glare and heat gain. This integrated approach, which merges energy conservation, energy efficiency, building envelope design and PV technology, takes full advantage of energy savings and maximizes the use of BIPV systems (Eiffert and Thomas, 2000).

The primary intent of this research study is to provide architects and designers with prototype PV design solutions and information on PV systems applications in multistory buildings. The principal research objectives include:

1. Evaluation of the electrical (physics) and engineering principles of PV panels that are applicable to multi-story-buildings.

2. Exploration of the factors that impact the deployment of PV panels in multistory building applications (e.g. impact of slope, orientation, shading from external structures, etc.).

3. Exploration of feasible and economical PV applications in multi-story buildings, to determine if PV panels are a possible solution based on cost analysis, environmental criteria, and energy consumption considerations. 
As more and more architects and designers gain experience in integrating photovoltaic systems into the built environment, this relatively new technology will begin to blend almost invisibly into the nation's urban and rural landscapes. This will take place if BIPV demonstrates an economical viability and the appropriate environmental characteristics. 


\section{Chapter 2: Photovoltaic system principles}

\subsection{Photovoltaic (PV) system history}

The PV panel concept was initiated when in 1839 a 19 -year-old French physicist, Edmund Becquerel, was able to produce voltage by illuminating a metal electrode in a weak electrolyte solution. Almost 40 years later, Adams and Day were the first to study the photovoltaic effect in solids. They were able to make cells out of selenium with 1 to $2 \%$ efficiency (Masters, 2005). Not long after this discovery, in 1904, Albert Einstein published his famous article on the photoelectric effect. Almost 15 years later, he won the Nobel Prize for his theories explaining the photoelectric effect. Seven years later, photovoltaic technology was born in the US when the first silicon PV cell with 6\% efficiency was made at Bell Laboratories. Early successful products included PV-powered dollar bill changers and devices that decoded computer punch cards and tapes (NREL, 2007).

In 1958, Mandelkorn of the US Signal Corps Laboratories fabricated crystalline silicon photovoltaic cells (DOE, 2007). This technology made cells more resistant to radiation and thereby made their use in space exploration more effective.

In the 1970s, with help from Exxon Corporation, Berman designed a significantly less expensive solar cell that brought the price down from $\$ 100$ per watt to $\$ 20$ per watt. This had a major effect on stimulating the PV industry. The stand-alone applications of PV panels began to be considered as feasible alternatives in remote 
areas where utility-grid connections were too expensive. PV cells were soon applied in navigation warning lights and horns on offshore gas and oil rigs, lighthouses, and railroad crossings. This event in addition to the growing concern for energy conservation encouraged more research and development investments by industry. In the same decade, the world's first laboratory dedicated to PV research and development, the Institute of Energy Conversion, was established in the University of Delaware with the focus on thin-film photovoltaic and solar thermal systems. At about the same time, RCA Laboratories produced the first amorphous silicon photovoltaic cells, which were less expensive to manufacture than crystalline silicon devices. However, this disadvantage did not affect the role of solar silicon cells accounting as a dominant technology in the solar cell market. These activities ultimately resulted in launching the Solar Energy Research Institute (today's National Renewable Energy Laboratory), a federal facility dedicated to finding and improving ways to harness and use energy from the sun. In this decade, NASA's Lewis Research Center installed a 3.5-kilowatt photovoltaic system on the Papago Indian Reservation in southern Arizona. This became the world's first village PV system. It provided power for water pumping and residential electricity in 15 homes until 1983 (NREL, 2007).

In the 1980s, PV panels were no longer a curiosity in research laboratories. The first megawatt-scale PV power station in the US went on line in Hisperia, California. It was developed by ARCO Solar and featured modules on 108 dual-axis trackers. The US Department of Energy (DOE) also began operating Solar One, which was a 10- 
megawatt central-receiver demonstration project in California. It established the feasibility of power-tower systems which include a solar-thermal electric system or a concentrating solar power technology (NREL, 2007).

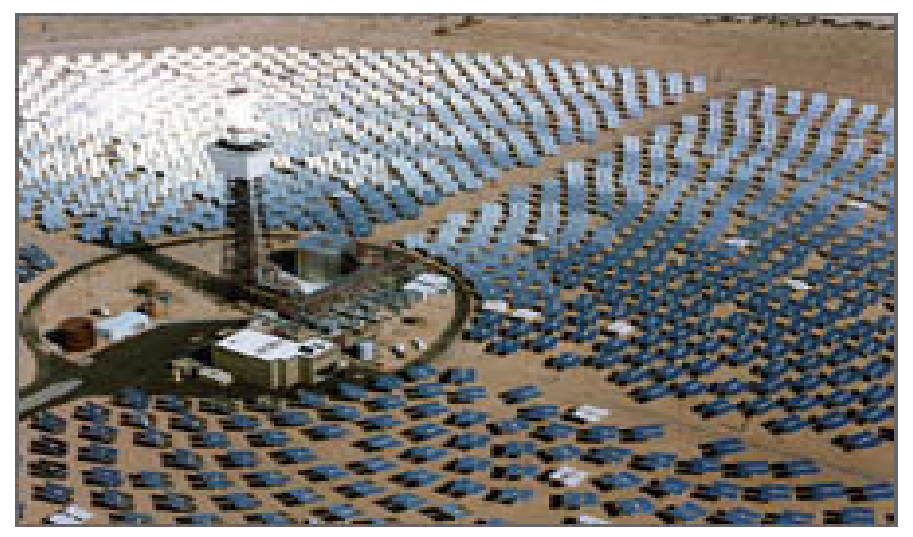

Figure 2.1: Solar One project in California (NREL, 2007)

In the same decade, Solar Design Associates completed a residential building powered by an integrated, stand-alone, 4-kilowatt photovoltaic system in the Hudson River Valley. It was the first house that drew all of its electricity from PV panels in the US (NREL, 2007).

In the early 1990s, Pacific Gas \& Electric installed the first grid-connected photovoltaic system in Kerman, California. The new technology not only reinforced the weak feeder in the sub-station but it also increased the reliability and peak-shaving capabilities of the system. The success of this project gave a boost to PV grid-connected systems (NREL, 2007). 


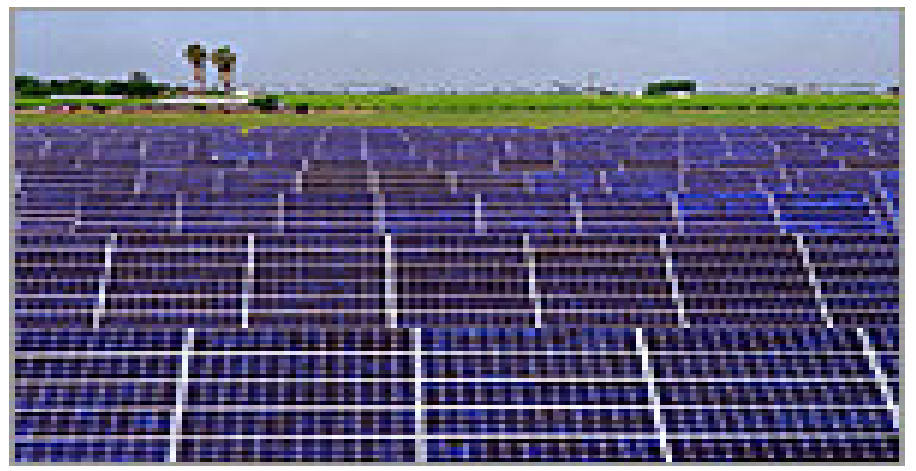

Figure 2.2: Grid-connected photovoltaic system in Kerman, California (NREL, 2007)

In 1992, approximately 40 years after the initiation of this technology, researchers at the University of South Florida developed a 15.9\% efficient thin-film photovoltaic cell made of cadmium telluride. This broke the $15 \%$ barrier of PV technology. Thin-film modules such as amorphous silicon can be deposited on a variety of low-cost substrates, such as glass and flexible metal sheets and provide a basis for BIPV panel technology.

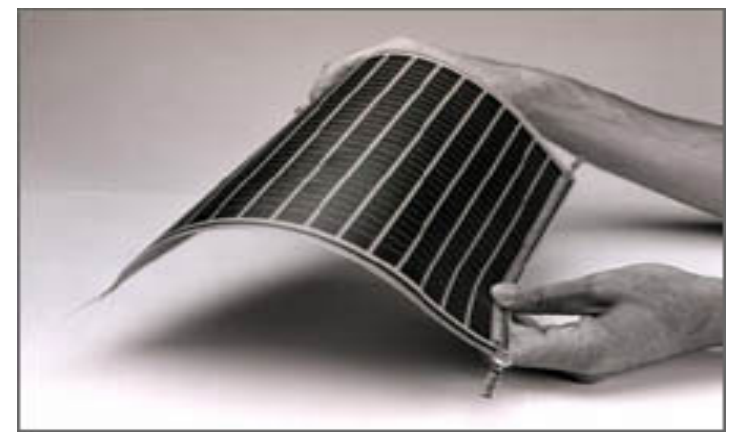

Figure 2.3: Thin-film modules (NREL, 2007) 
One year later, another major step toward the development of this technology was taken when a scientist, well known for his pioneering work in amorphous silicon, Subhendu Guha, invented flexible solar shingles. Photovoltaic shingles are mounted directly onto a roof, taking the place of asphalt shingles. (NREL, 2007).

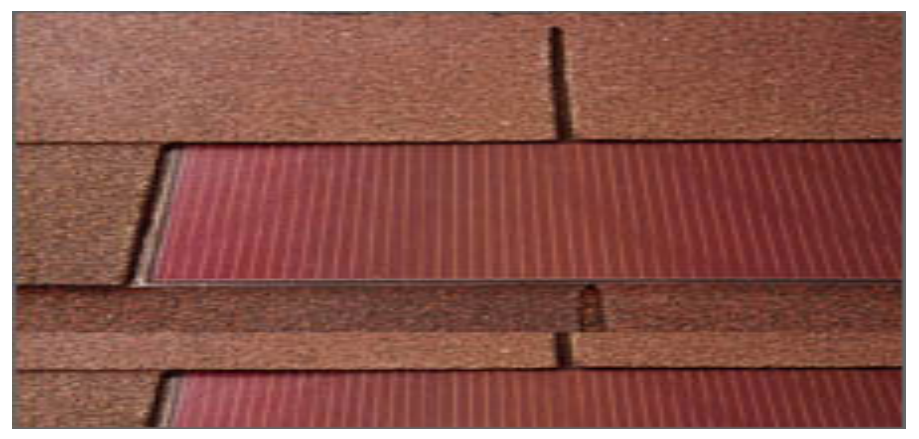

Figure 2.4: Amorphous silicon PV shingles (NREL, 2007)

In 1999, the construction of the 4 Times Square building in New York with BIPV panels was completed. Apart from being one of the tallest buildings in the city, it also includes more efficient features than any others have. One of the 4 Times Square's advanced features is its photovoltaic skin in which thin-film PV panels replace traditional glass cladding material. The Durst Organization ${ }^{1}$ developed the building incorporating many energy-efficient features. Kiss+Cathcart architects designed the PV system along with Fox and Fowle, the original building designers. Energy Photovoltaic of Princeton, New Jersey, designed the custom PV modules. This building is claimed to be operating in good conditions. The economical feasibility of the system is based on high tax incentives and high leasing prices. The

\footnotetext{
${ }^{1}$ The Durst Organization is a major owner and operator of Manhattan commercial real estate.
} 
building was completely leased upon completion. This case is reviewed in details in chapter four as a case study.

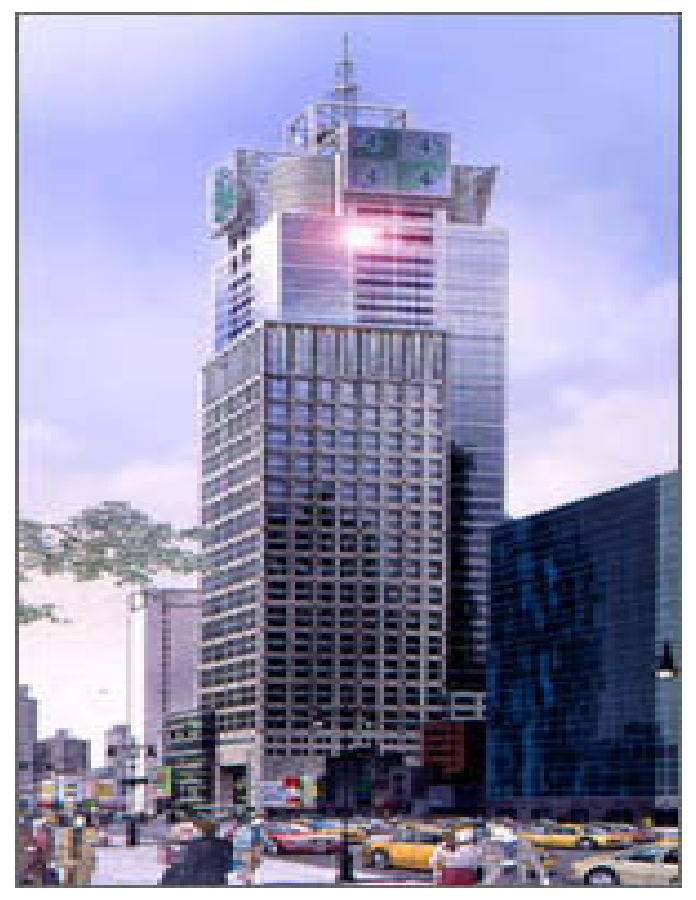

Figure 2.5: 4 Times Square building in New York (NREL, 2001)

In 2000, Spectro Lab, and the NREL developed a 32.3\% efficient solar cell. This higher efficiency was a result of combining three layers of photovoltaic material into a single cell. This was considered the most efficient and practical approach for devices with lenses or mirrors to concentrate the sunlight. The concentrator systems are mounted on trackers to keep them pointed toward the sun. Recently, researchers at NREL developed a prototype thin-film solar cell that is $18.8 \%$ efficient, topping the previous record for thin-film cells by more than $1 \%$. Cumulative installed photovoltaic capacity reached 1000 megawatts by 2005 (DOE, 2007). 
Although the PV industry is only about 60 years old, during this time the efficiency has improved significantly (from $6 \%$ to $32 \%$ ). At the same time, the cost of PV systems has decreased from $\$ 100 / \mathrm{WP}^{1}$ to $\$ 3.5 / \mathrm{WP}$ (NREL, 2007). Several countries around the world including the US have recognized this potential and encouraged the development of solar energy.

${ }^{1}$ Watt power 


\subsection{PV system overview}

\subsubsection{The PV cell}

Photovoltaic cells are semiconductor devices that convert solar energy directly into electricity. Sunlight is comprised of photons, or particles of solar energy. These photons contain various amounts of energy corresponding to the different wavelengths of the solar spectrum. PV cells respond mainly to visible radiation (wavelengths of approximately $400 \mu \mathrm{m}$ to $700 \mu \mathrm{m}$ ). When photons strike a PV cell, some of them are reflected, some absorbed, and some may pass right through the cell. However, only the absorbed photons generate electricity. The absorption characteristics of PV cells obviously affect the design. For example, normal glass contains traces of iron. This characteristic causes the glass to respond more effectively to the visible green range. Since PV cells can use this energy, they incorporate low-iron glass.

As illustrated in Figure 2.6, the absorbed photons will produce an electric field in the semiconductor $^{1} \mathrm{p}-\mathrm{n}$ junction ${ }^{2}$. Electrons influenced by this electric field tend to flow to the surface. The flow of electrons or current can be either used immediately (in such case an inverter is needed), or it may be stored, as in a battery, for later use. PV cells are manufactured in the same way as semi-conductor devices. However, the

\footnotetext{
${ }^{1}$ Semiconductor is a material that has no conductivity unless an external voltage disturbs the balance of its system. Temperature, light or impurities can produce this voltage.

${ }^{2} \mathrm{p}$-n junction refers to a junction between a n-type layer and a p-type layer. This junction forms when either group V or III impurities (such as phosphorous and boron, respectively) are added to the semiconductor.
} 
stringent requirements for cleanliness and quality control of semiconductor fabrication are a little more relaxed for solar cells (Randell, 2006).

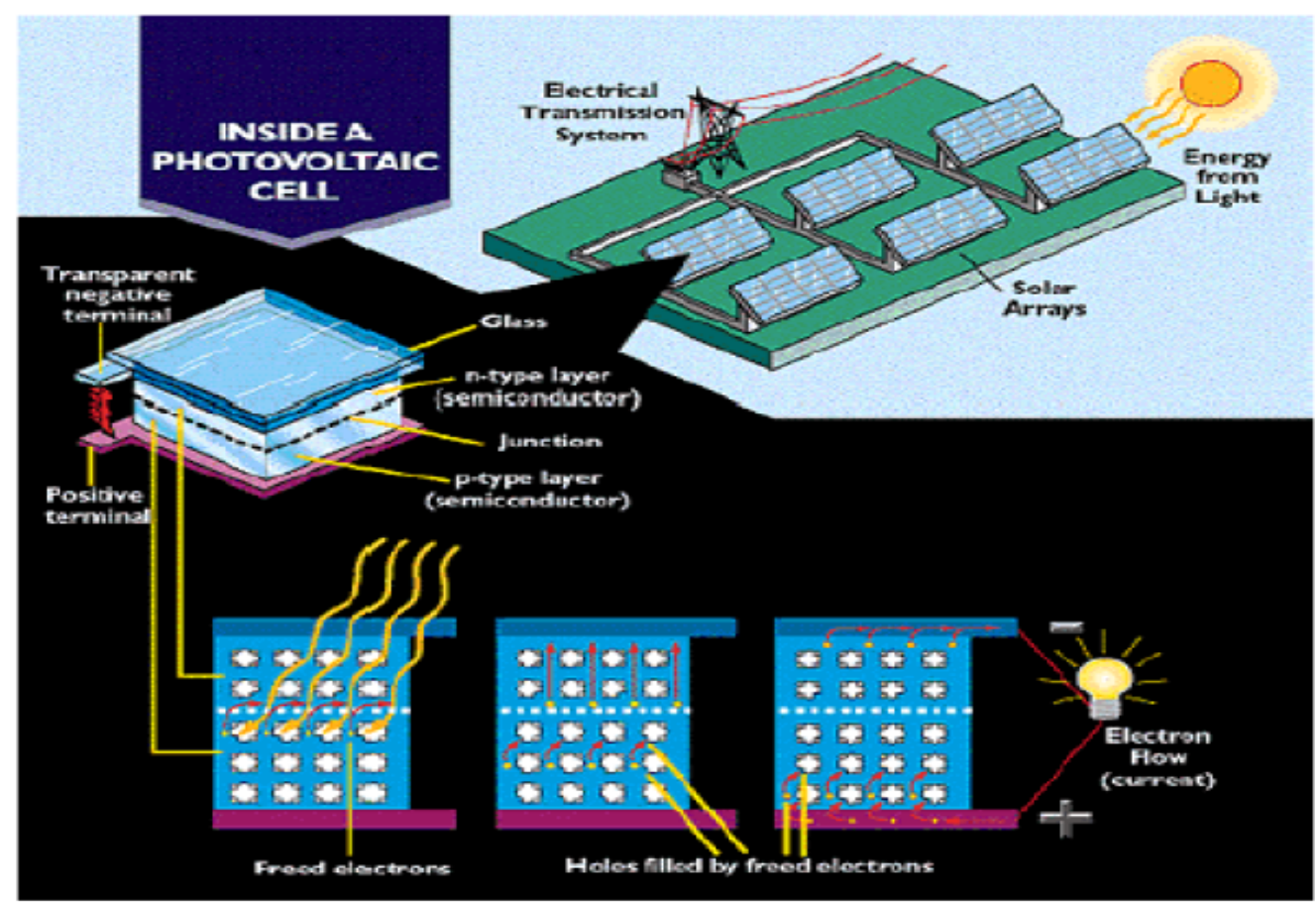

Figure 2.6: Inside a photovoltaic cell (San Diego Regional Renewable Energy Study Group, 2005)

An ideal solar cell has the same characteristics as a diode ${ }^{1}$ as shown in Figure 2.7. In practice, no solar cell is ideal, so a shunt (i.e., parallel) resistance and a series resistance component are added to the model. The series resistor represents any voltage drop between the junction and contacts of the PV cell, while losses on the edges of the cell result in the formation of the shunt resistor (Messenger, 2004). In order to increase the efficiency, the objective is to decrease the effects of these resistors.

\footnotetext{
${ }^{1}$ Diode is an electronic device that only allows current to flow in one direction.
} 


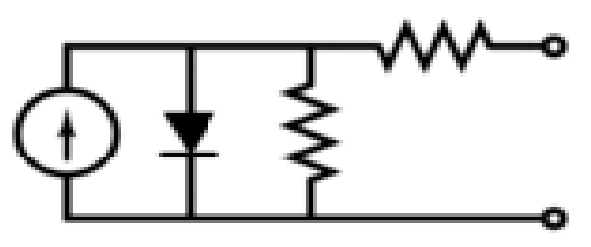

Figure 2.7: Equivalent circuit of a solar cell (Wikipedia, 2007)

Since a single PV cell produces less than 3 watts at 0.5 volts DC, PV cells must be connected in series and parallel configurations for high power applications. PV systems are commonly operated at multiples of $12 \mathrm{~V}^{1}$. Considering losses, this suggests a target design of $18 \mathrm{~V}$ or 33 to $36 \mathrm{PV}$ cells in series ${ }^{2}$. Figure 2.8 shows the schematic symbol of a PV module. Cells in series and parallel configuration form a module. Modules in series and parallel configuration form an array.

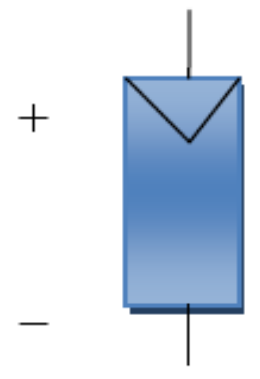

Figure 2.8: The schematic symbol of a solar cell

\footnotetext{
${ }^{1}$ Since most of the batteries and appliances work with $12 \mathrm{~V}$, PV systems are normally designed based on this voltage.

$2(36 \times 0.5)=18 \mathrm{~V}$ 
Formation of PV cells, modules and arrays are shown below in Figure 2.9 (Messenger, 2004).

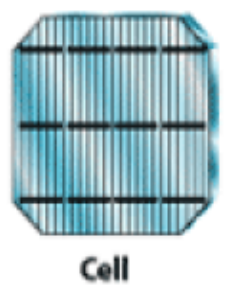

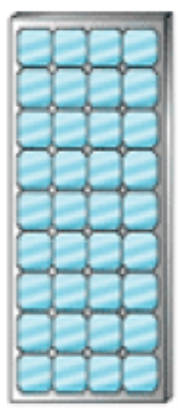

Module

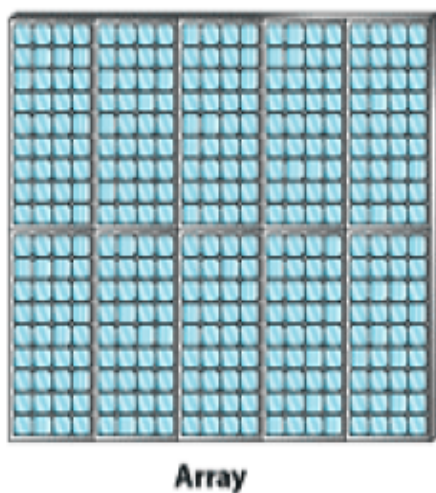

Array

Figure 2.9: Cells in series form a module. Modules in series-parallel configuration form an array. (San Diego Renewable Energy Study Group, 2005)

For purpose of standardization and comparisons, PV cells are tested under standard test conditions (STC) of $25^{\circ} \mathrm{C}$ and $1000 \mathrm{~W} / \mathrm{m}^{2}$ solar intensity. Solar radiation intensities are commonly normalized with respect to full sun solar radiation at sea level with average humidity and aerosol particulate concentration. Atmospheric conditions are commonly referred to as air mass (AM) 1.5. The solar radiation at AM 1.5 is approximately $1000 \mathrm{~W} / \mathrm{m}^{2}$.

Figure 2.10 shows a typical curve of PV cell performance under STC. When the load resistance connected across the terminals of the cell is zero, the current is at its highest value (point A), which is referred to as short circuit current $\left(\mathrm{I}_{\mathrm{sc}}\right)$. When the value of the load resistance is extremely high, the voltage is at the highest level 
(point $\mathrm{D})$, which is referred to as open circuit voltage $\left(\mathrm{V}_{\mathrm{oc}}\right)$. The product of current and voltage results in power ${ }^{1}$. The maximum value of power occurs at the knee of the curve (somewhere between point $\mathrm{B}$ and $\mathrm{C}$ ), which represents the maximum power point (MPP). The corresponding current and voltage are referred to as $I_{\max }$ and $\mathrm{V}_{\max }$ respectively. MPP plays an important role in efficient PV systems. There are electronic devices referred to as MPP trackers. They constantly monitor the system to ensure operation at maximum efficiency.

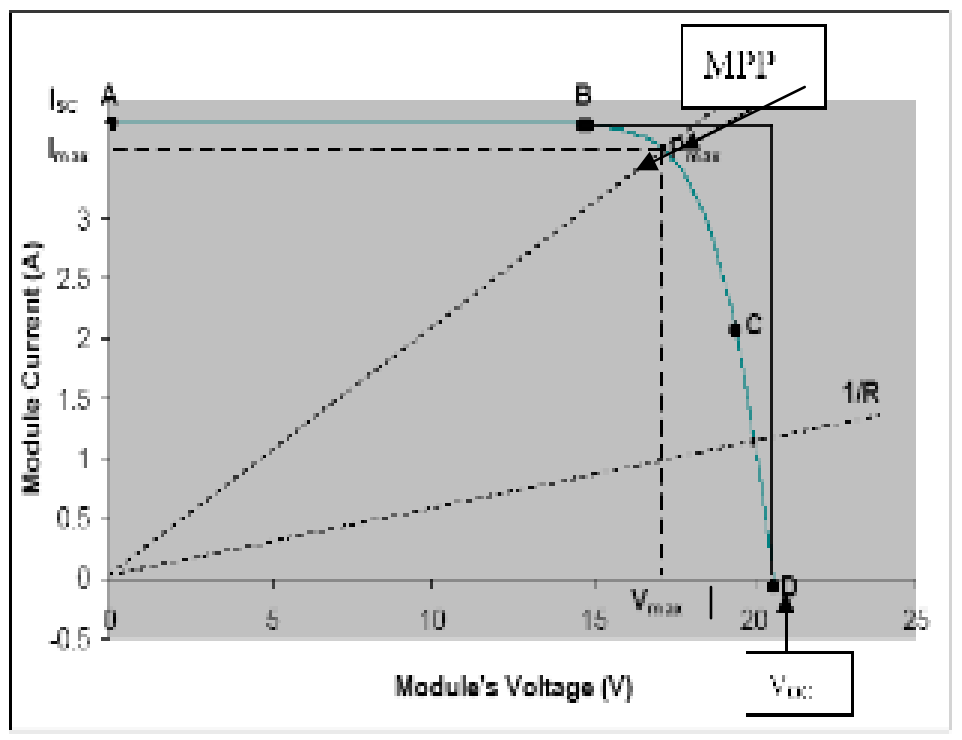

Figure 2.10: I-V curve, MPP, $\mathrm{I}_{\mathrm{sc}}, \mathrm{V}_{\mathrm{oc}}$ (Thah, 2003)

$\mathrm{I}-\mathrm{V}$ curves are the key determining factors in designing a PV system. These curves are based on the PV type and subject to change by several variables such as temperature, amount of radiation, and shadowing. Furthermore, based on the high electrical consumption of commercial multi-story office buildings, there is a need to

\footnotetext{
${ }^{1} \mathrm{~V}($ Volts $) \times \mathrm{I}($ Ampere $)=\mathrm{P}($ Watts $)$
} 
use all the applicable area, including roof, façade, and sunshades of the building. This requires the use of different types of panels with different I-V characteristics, and makes the use of PV panels more challenging in multi-story buildings. Ultimately, the aim should be to use PV panels with very similar I-V curves, otherwise the efficiency of the total system decreases. These effects are discussed in the next chapter. 


\subsubsection{The components of a solar system}

Solar PV systems are generally categorized into two groups, namely stand-alone systems and grid-connected systems. Based on prior arguments, grid-connected or utility-interactive systems appear to be the most practical application for multi-story buildings where the available surface is both scarce and expensive. Grid-connected solar power systems supply power to the building while connected to the external utility system. Thus, if the demand is more than the immediate PV supply, the system draws the required supplementary power from the utility grid. If the PV energy is in excess of the building demand, then the surplus can be sent back to the utility (Thah, 2003).

However, there are certain regulations that govern the connection of PV systems to the utility grid, in particular to overcome problems related to balancing the system. Utility companies in each region determine these regulations and the buy-back rate of the energy generated by the PV panels.

Generally, on-grid solar PV systems consist of the following components:

1. PV panels (either in the form of BIPV or PV arrays on the roof)

2. Power Conditioning Unit (PCU): This is a general term for devices that convert the energy derived from arrays to energy suitable for the building. The inverter is the principal component of a PCU. Generally a PCU includes: 
a. Inverter: To convert DC into AC, because all of the appliances in the building work with AC. The inverter has to be matched with the wattage output of the solar panels. There are generally two main distribution strategies. In a centralized strategy, all of the modules are connected to one large inverter, while in a distributed strategy each module or string is equipped with its own inverter. The latter design is usually referred to as a "string inverter". Since in multi-story buildings PV panels may possibly be placed in different parts of the building, a string inverter is often a good alternative.

b. Maximum Power Point Trackers (MPPT): These electronic devices track the maximum power at any time based on I-V curve characteristics. Although they add extra cost to the system, they are effective in maximizing system efficiency.

c. Kilowatt Hour Meter (2-way meter): Although in some cases one-way meters are used for economic reasons, they are not reliable in large scale productions. In addition, the end-user should also be aware of energy variations.

d. Array DC disconnect: These are devices that allow halting of the flow of electricity from the array during system maintenance. Disconnects are required as part of the final electrical inspection of the system. 
e. AC breaker panel (fuse): A fuse is required for safety and protection purposes.

f. Protection devices: They include the protection relays and devices used to protect the system from surge creation or overloading ${ }^{1}$.

3. Wiring of the components: This includes the building electrical panel, and all the electrical connections (Thah, 2003).

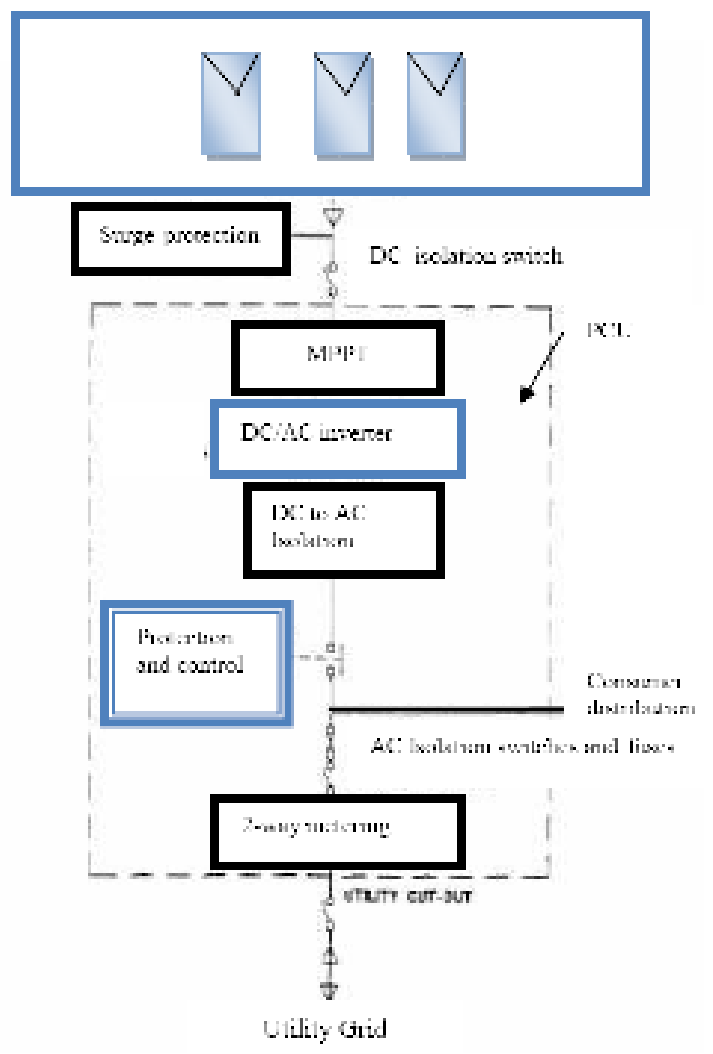

Figure 2.11: Schematic diagram of a complete on-grid PV system (Thah, 2003)

${ }^{1}$ A surge will occur when the current exceeds the rated current of the electrical device. 
If the external utility has outage problems, the system might include battery storage for back-up power. Consequently, in case of an emergency or when a power outage occurs, the PV system can switch to an uninterruptible power supply (UPS) system ${ }^{1}$. However, due to space restrictions and battery losses this option is not normally recommended. Generally, grid-connected systems are most efficient when the array experiences uniform ${ }^{2}$ conditions (Thomas and Fordham, 2001).

\footnotetext{
${ }^{1}$ PV systems appear to be the most suitable candidates for UPS systems due to their reliability for short-term operations.

${ }^{2}$ Shadowing should be avoided.
} 


\subsubsection{Types of PV panels}

There are different types ${ }^{1}$ of PV panels that can be integrated into the building envelope or placed on the roof of the building. Based on their thickness, PV panels can be categorized into two groups: conventional crystalline solar cells $(200-500 \mu \mathrm{m}$

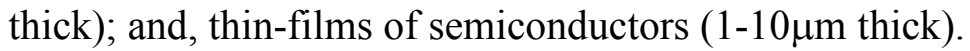

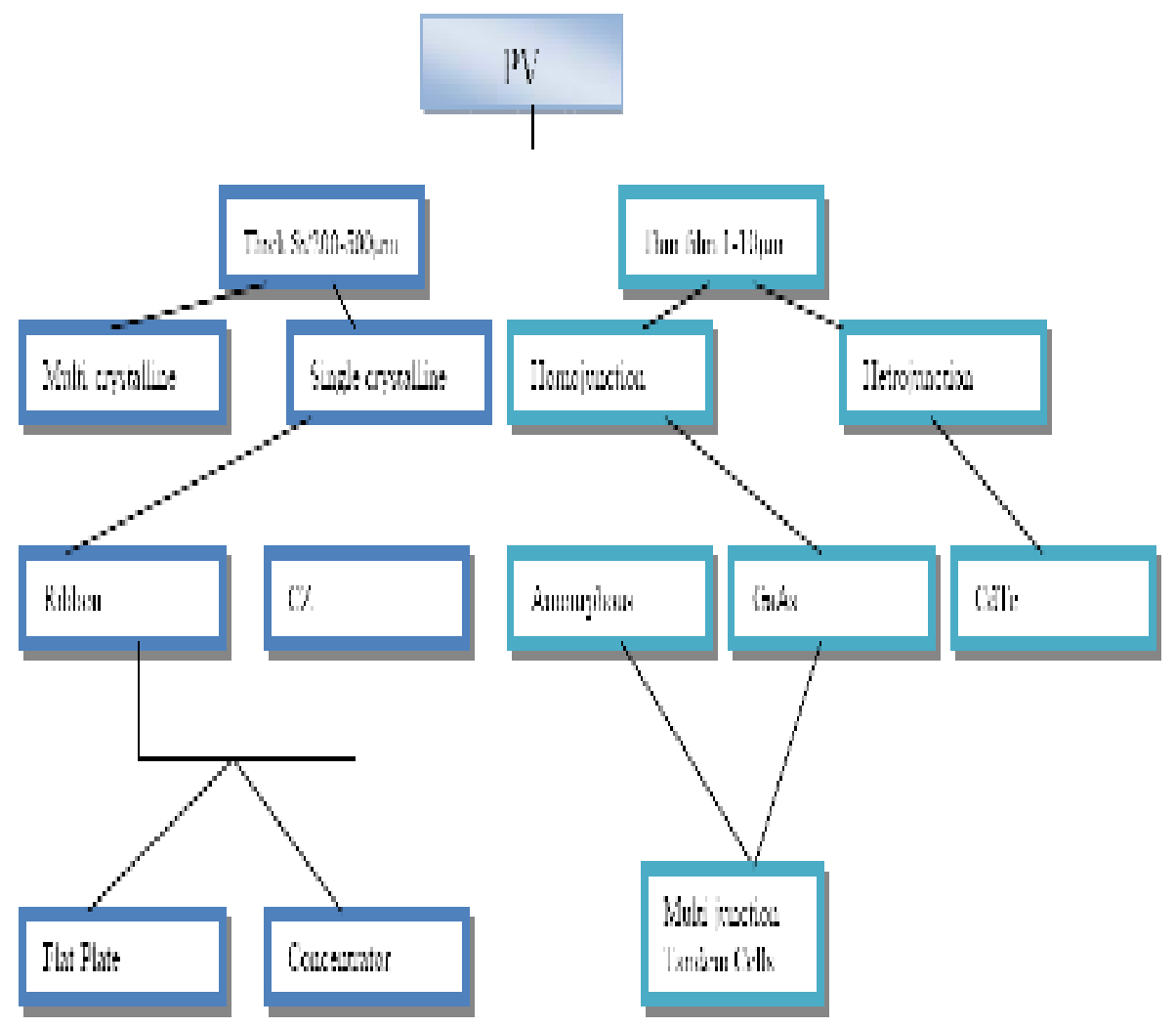

Figure 2.12: Summary of different types of PV cells ${ }^{2}$

\footnotetext{
${ }^{1}$ There are several emerging technologies in PV systems that are not yet commercially available for multi-story buildings.

${ }^{2}$ This categorization is based on PV cell junctions. However, there are several other different ways to categorize PV systems. 
PV technology can also be categorized by the size of the crystals in the cell, as shown in Figure 2.12. Conventional crystalline silicon ( $\mathrm{Si}$ ) is the oldest and most reliable technology and consists of individual thick cells that are wired together to provide the desired voltage and current. It can be broken down into single crystalline and multi-crystalline (also referred to as poly-crystalline) forms.

\section{Single-crystalline:}

This is the dominant technology on the market with the highest efficiency (12-22\%). However, the manufacturing process for this type of PV cell is highly intensive and expensive compared to all of the other types of PV panels. Several methods are suggested to reduce the cost and complexity of production. Two of the most common manufacturing methods are:

1. Single-Crystal Czochralski (CZ) Silicon: This is the most commonly used method to form a crystal of silicon from $99.9999 \%$ pure silicon. In this method, silicon is shaped into wafers and each wafer undergoes several production steps to become suitable for commercial use.

2. Ribbon: This is another method to grow a ribbon of silicon out of molten silicon. This method is a new method developed by Siemens and it is not used in PV production as much as CZ. The method deploys the recycled silicon from former semiconductor devices and reshapes it to new crystalline silicon (Gevrokian, 2006). 
Some cells are specially designed to operate with concentrated sunlight, while others are used in non-concentrating flat-plate systems. Concentrators are lenses or reflectors that focus sunlight onto the solar cell modules. However, Concentrating $\mathrm{PV}(\mathrm{CPV})$ is the least mature technology in respect to megawatts deployment and is still very costly.

Multi-crystalline:

In this method, the silicon melt is cooled very slowly under controlled conditions. The cell contains relatively large areas of single crystalline grains, each on the order of $1-\mathrm{mm}$ to $10 \mathrm{~cm}$ in size. Although this technology yields relatively inexpensive products, its efficiency is less than single crystalline technology (i.e., 11-15\%). This technology is especially popular in Europe.

Silicon crystalline cells can be laminated in layers of material that offer structural support and weather protection. As shown in Figure 2.13, the upper level is tempered glass. The next layers are made of ethelyn vinyl acetate (EVA) that encapsulate the cells. The last layer is a sheet of polymer to prevent moisture penetration. The last layer can also be a glass sheet, which is more suitable in the BIPV application. 


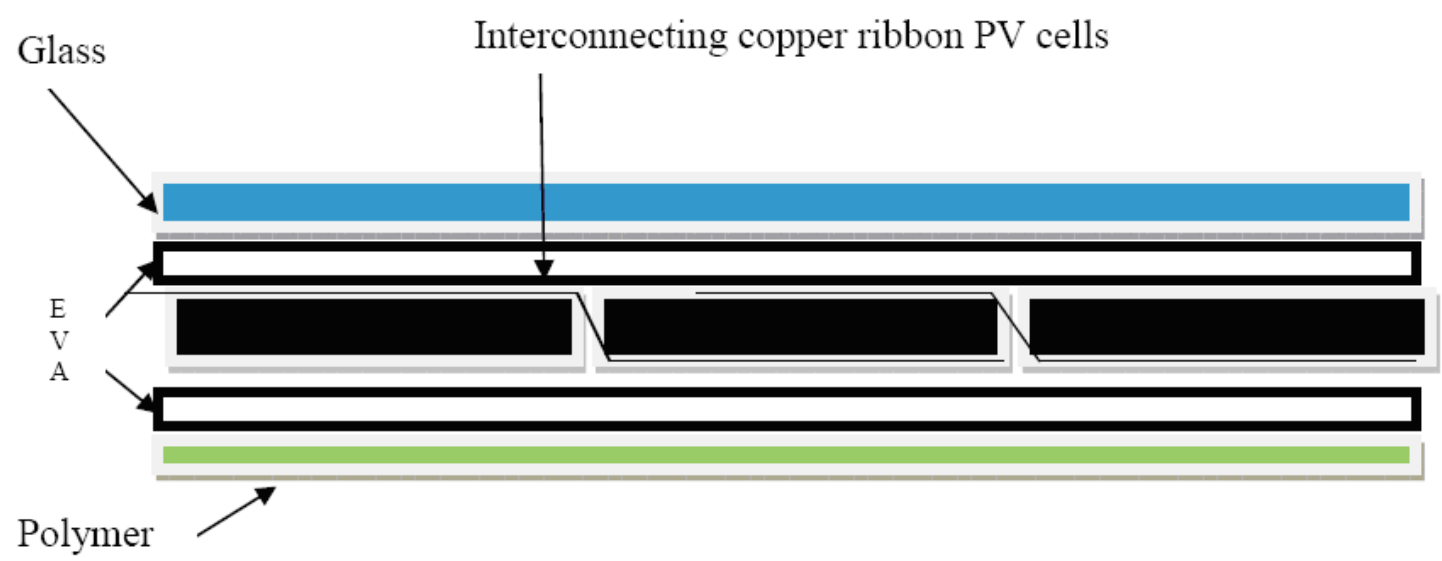

Figure 2.13: A Si PV cell

Conventional silicon crystal technology requires a considerable amount of expensive material with additional complexity and extra costs in wiring the individual cells together. On the other hand, thin-film technology requires relatively less material, and it is less costly and not as complex as conventional silicon crystal. The thinness and semi-transparency of thin-film PV panels make them relatively appropriate for BIPV applications. Thin-film technology is based on depositing extremely thin films of material onto a glass or metal substrate. However, the only drawback of this technology is its low efficiency (about 10\%). Thin-film technology can be categorized into two groups based on the type of junction:

1. Hetro-junction: This refers to a cell in which different materials are added on each side of the junction. CdTe appears to be one of the most successful technologies within this group. These cells are significantly cheaper than Si-crystalline cells. Texas-Instruments used CdTe on 
calculators for years. However, there is increasing concern about their use in full-scale modules for large-scale applications, since; CdTe modules contain about 6 grams of cadmium per square meter. This material can be extremely toxic (Masters, 2004). Nevertheless, it is commonly used in glass-substrate PV cells (Kiss and Kinkead, 1995).

2. Homo-junction: This refers to a cell in which a single material is added on both sides of the junction. Amorphous silicon, which is one of the most commonly used technologies in thin-film applications, is included in this group. In amorphous silicon there is barely any order in the arrangements of atoms. A-Si-H is a combination of silicon and hydrogen atoms that are not in crystalline form. Figure 2.14 shows a cross-section of an $\mathrm{A}-\mathrm{Si}-\mathrm{H}$ cell that uses either glass or metal as a substrate. The next layer is commonly a buffer layer of silicon dioxide that may be deposited to prevent atoms from migrating into the glass. The next layer is the electrical contact. It is usually made of an oxide such as tin-oxide. As shown in Figure 2.14, the junction is very thin ${ }^{1}$ and consists of a p-layer, an intrinsic ${ }^{2}$ region and a $\mathrm{n}$-layer. Aluminum as a contact is the last layer.

\footnotetext{
${ }^{1}$ Thickness of the whole cell is only about $1-10 \mu \mathrm{m}$

${ }^{2}$ No impurity is added to this region.
} 


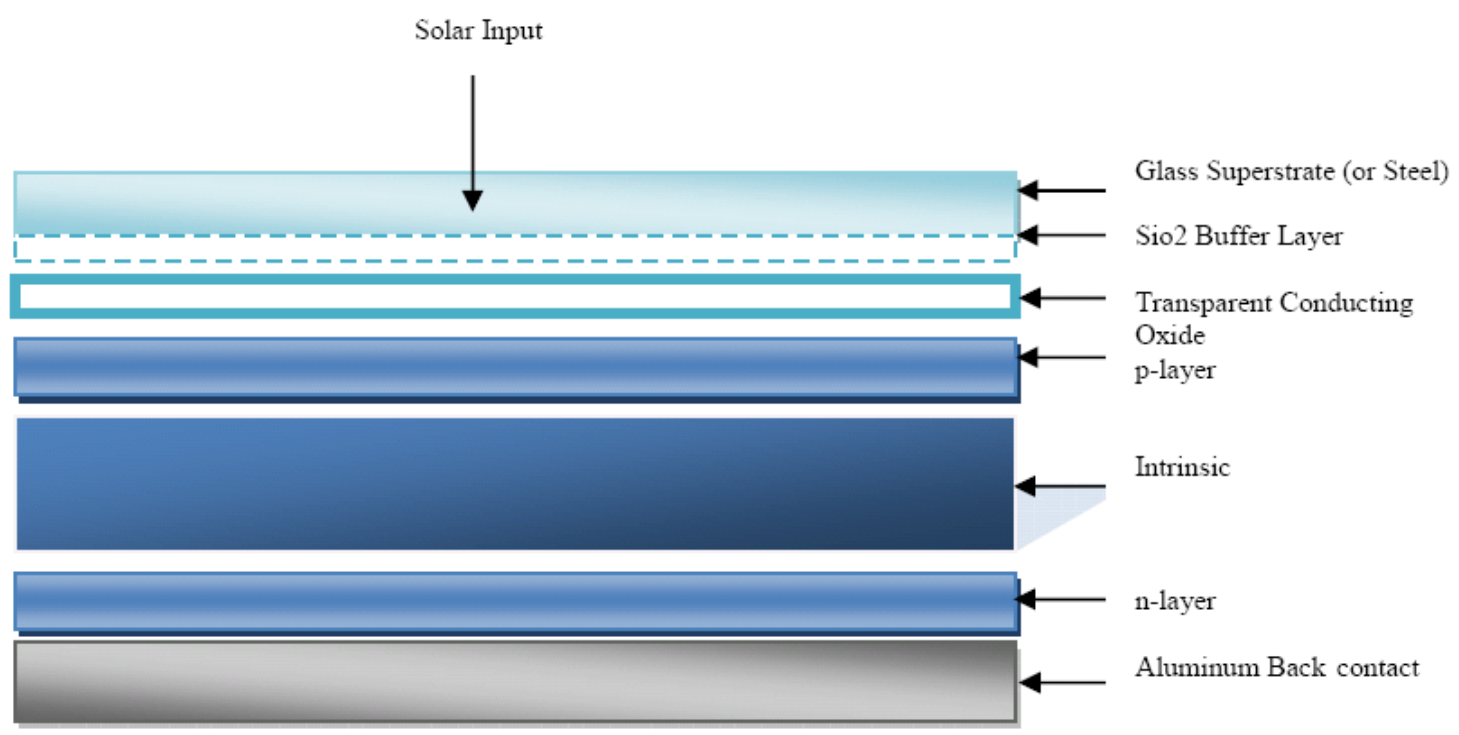

Figure 2.14: Cross-section of an amorphous module with a glass superstrate.

Some A-Si cells use a thin, flexible stainless steel superstrate instead of the glass.

Stainless steel provides the mechanical strength needed, while its flexibility allows these modules to be rolled up and stored (Eiffert and Kiss, 2000).

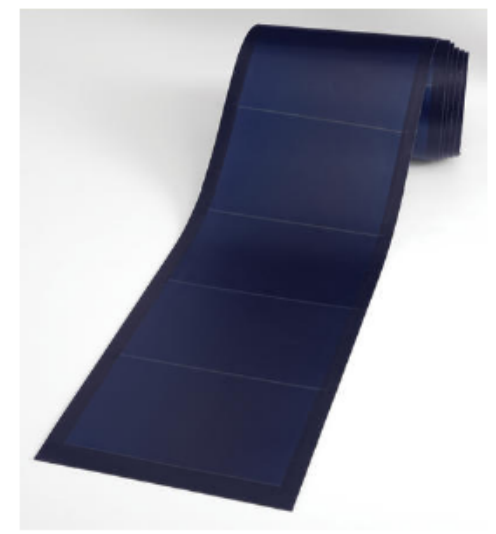

Figure 2.15: Thin-film metal superstrate (San Diego Renewable Energy Study Group, 2005) 
GA/As:

These are the most efficient single junction solar cells $(39 \%$ with solar concentration). They are also lightweight, insensitive to temperature increases and less affected by radiation. On the other hand, gallium is not as abundant as silicon and its manufacturing cost is much higher, therefore, it is only used in space applications (Masters, 2004).

\section{Multi-junctional:}

These groups consist of compounds made of a number of elements to find a combination with optimum efficiency. Copper indium deselenide (CIS) belongs to this group. They are commonly employed in glass-based technology. Their efficiency in the laboratories is about 20\% (Masters, 2004). The structure of these cells is shown in Figure 2.16.

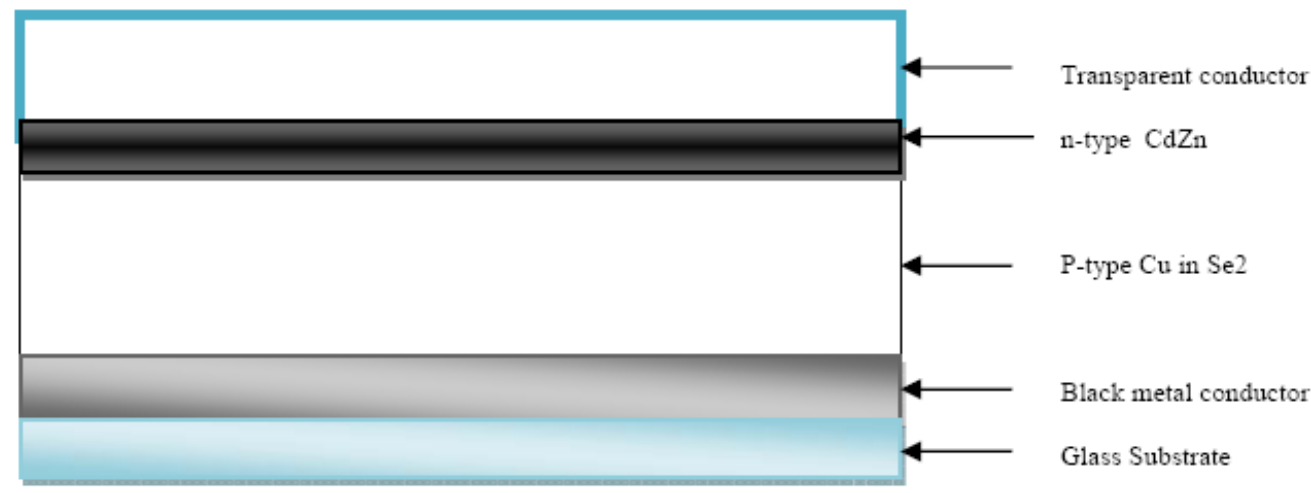

Figure 2.16: A CIS module. 
A comparison of different applications of PV panel types is shown below in Figure 2.17 .

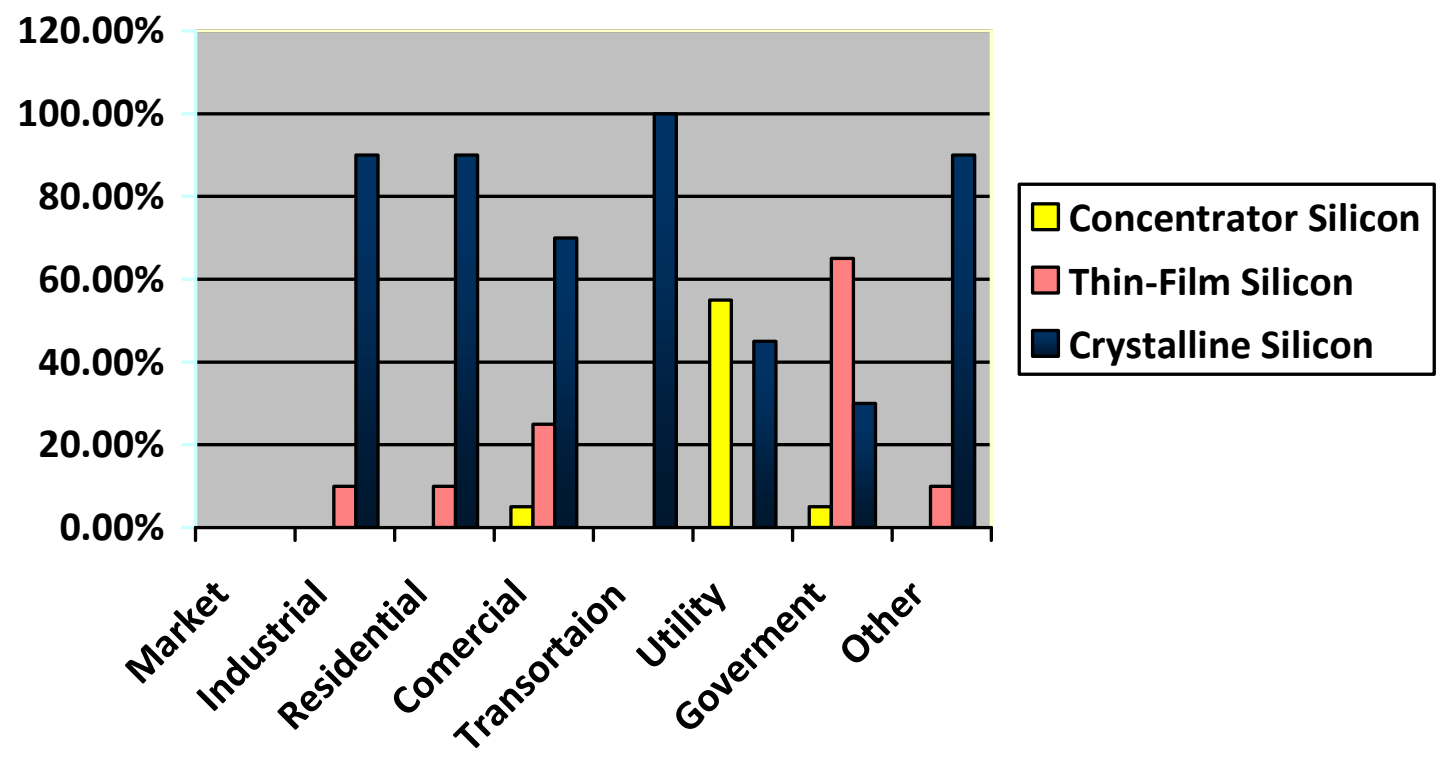

Figure 2.17: Distribution of PV cells and modules in various applications, 2003-2005 (DOE, 2005) 


\subsubsection{Types of PV panels suitable for multi-story buildings}

Several advantages in applying BIPV panels to commercial multi-story buildings are claimed:

1. Low installation cost: BIPV panels cost slightly more than the conventional material that they replace, specially if they are deployed in the form of thin film technology (Kiss and Kinkead, 1995).

2. The operational hours of the office building coincide with the peak power production time of PV systems (Gevorkian, 2006).

3. They do not require additional land use, since the building surface is used to accommodate the PV panels (Gevorkian, 2006).

However, BIPV systems are constrained by design, shading elements and owner preference. The building design should also consider the ease of installation and integration and follow the building regulations. Commonly, their installation is more complex and requires experts in PV system technology, because they involve high voltage systems. Safety and waterproofing can raise additional problems in this type of design. Safety is one of the primary requirements. The requirements for PV experts add extra expenses to the project, which is usually ignored during the initial 
design stage. Generally, PV installers are mostly electrical contractors who may not be familiar with this technology because of the small number of PV installations. In addition, a PV installation is limited by building orientation. A southern orientation in the northern hemisphere allows the radiation over the surface of the cell to be maximized, but this also generates a large amount of heat. Due to their direct exposure to solar energy and ventilation limitations, the BIPV panels have to operate at higher temperatures. This factor is discussed further in the next chapter as a part of PV panel losses.

There are also many additional constraints and unpredictable costs associated with retrofitting an existing structure. For example, re-cladding a building with a PV curtain wall is a very similar process to re-cladding with a conventional curtain wall, with the exception that wiring must be accommodated. This makes the entire process more complex. Retrofit applications might perform as well as new installations, but each retrofit project must be evaluated individually. Generally, it is easier to plan PV panels at the building design stage. However, either way adds complexity and costs to the design of multi-story buildings.

PV panels that are deployed as an integral component of a multi-story building may be window-based or metal-based. 
Window-based PV panels:

These are the only PV products available today that can be readily integrated into existing buildings. As mentioned in the previous chapter, glass-to-glass PV modules are fabricated in several different ways. The following examples illustrate some of the most common PV module types suitable for multi-story buildings:

1. Window-based crystalline silicon modules (single-crystalline and multicrystalline silicon PV modules) (Figure 2.13).

2. Thin-film modules: These include amorphous silicon, CIS, and CdTe modules. They are either superstrate-based, where the PV film is applied to the bottom surface of the top layer of glass or substrate-based, where the surface is on top of the glass. Amorphous silicon and CdTe are superstratebased modules (Figure 2.14), while CIS modules are substrate-based (Figure 2.16).

Several different methods are employed to replace conventional architectural glazing with PV panels:

- Opaque PV glazing: Any PV panel can replace spandrel glass, if the size and visual quality of the module are compatible with the building design. Very close visual 
matches are thin-film amorphous PV modules, because they are very thin and lightweight, however, their efficiency is low.

- Semi-transparent PV glazing:

Currently available PV products are not adequately transparent to replace vision glass. However, there are many applications for semi-transparent glazing in which PV panels are suitable substitutes. Exterior curtain wall structures in multi-story buildings often use heavily tinted or patterned glass to diminish heat gain or control glare. Most large-area thin-film modules are partly transparent as a result of thin lines scribed through the cell material. Single crystal or polycrystalline BIPV modules can pass the light through the space between each cell, and light transmission is easily controlled by varying the space between cells. However, PV cells require some modification for each design criterion just like regular glass (Kiss and Kinkead, 1995). The economic feasibility of a PV system can be determined by a comparison with the type of glass being replaced. 


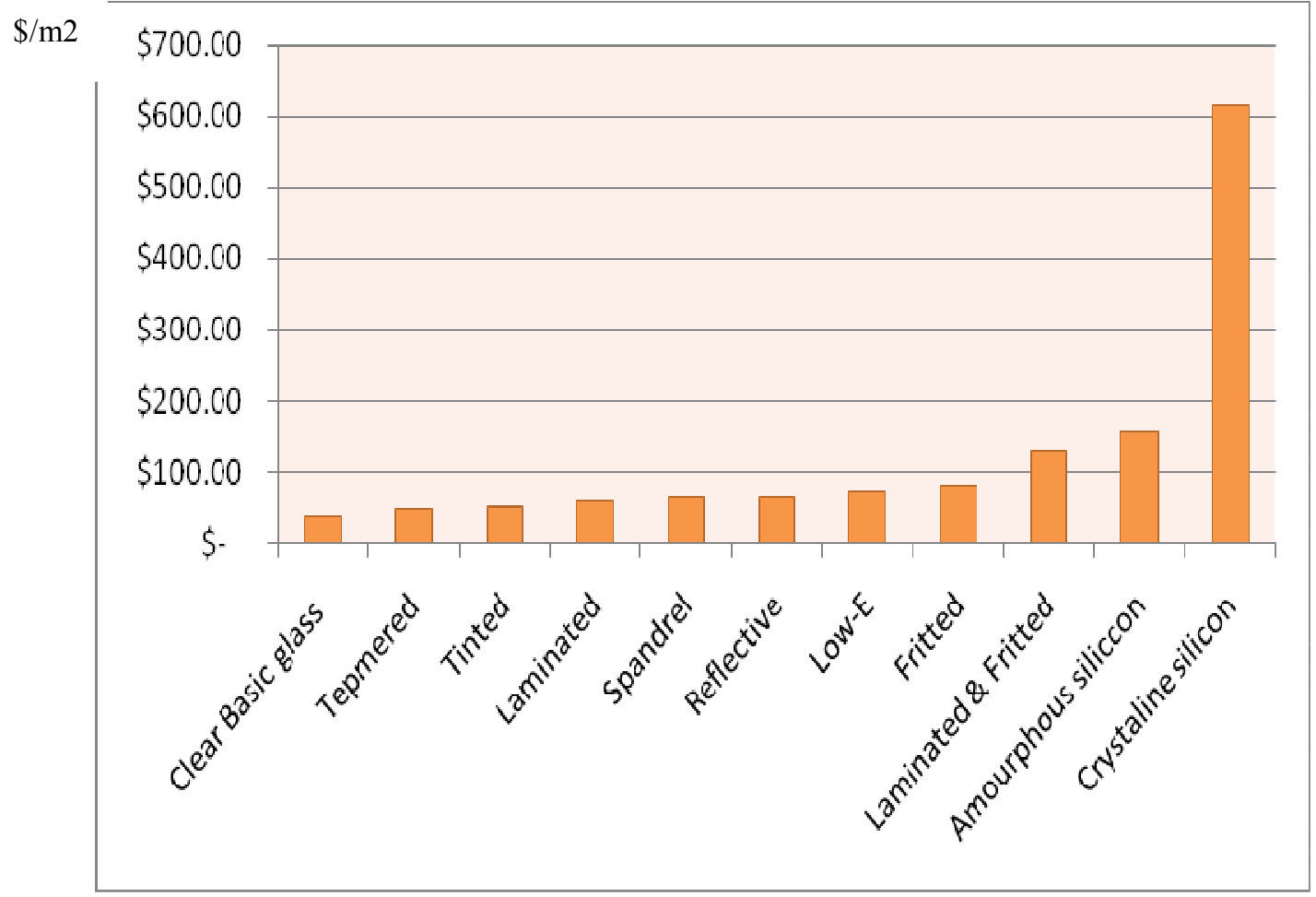

Figure 2.18: A comparison between different types of glass and currently available PV modules (Kiss and Kinkead, 1995)

Figure 2.18 shows a comparison between different types of glass and current costs of window-based PV panels. For example, if the cost of the PV panel is $\$ 150$ and the cost of the spandrel glass is $\$ 80$ for square meter then the additional cost of the PV panels is only $\$ 70$ for square meter. However, glazing is also associated with the amount of daylight available in a building. Sometimes PV glazing may be in conflict with the low-energy design of a building. PV glazing may result in loss of view and daylight. Although PV panels have high glazing factors (about 30\%), their U-value ${ }^{1}$ is relatively low. These factors increase the complexity of the design and limit the application of PV technology in the buildings, particularly, multi-story buildings.

\footnotetext{
${ }^{1} \mathrm{U}$-value defines how much heat a building material conducts. $\mathrm{U}$ value is the reciprocal of the thermal resistivity of a multi-layered construction assembly.
} 
3. Metal substrate or superstrate PV panels:

Due to their flexibility, these PV panels can replace sheet metal on the roof or façade of a building. However, they are not as suitable as window-based systems, because in order to be applied in a building they need to be customized for the building design, which can be costly. As a result, metal substrate thin-film modules are commonly used in roof applications (Thomas and Fordham, 2001). This fact reduces their application in multi-story buildings where the availability of roof area is limited.
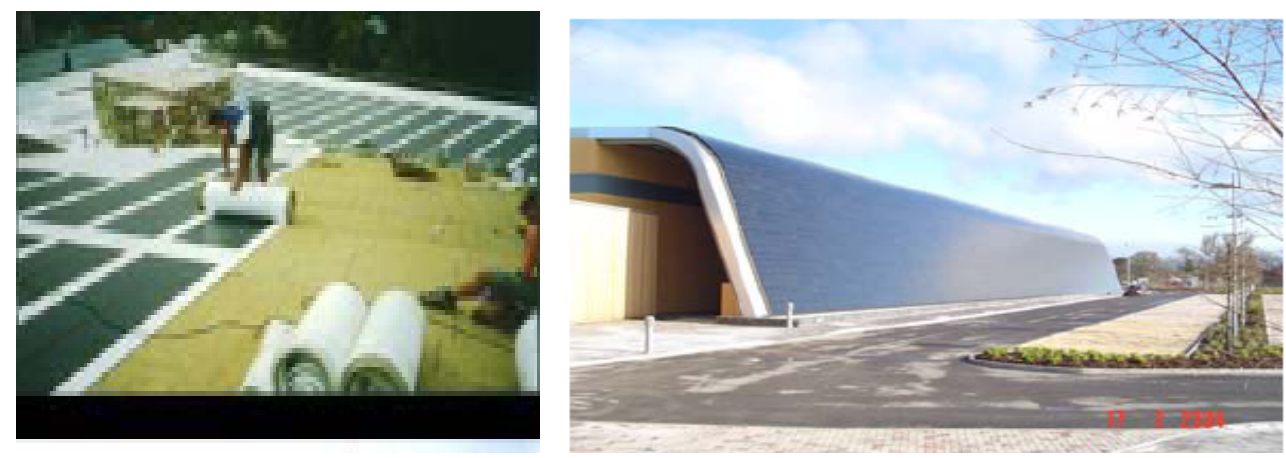

Figure 2.19: Thin film metal substrate applied on the roof and façade systems of a building in the United Kingdom (UK) (Witkopf et al., 2004)

Apparently, the customized metal based PV panels for multi-story building applications are more diffcult and costly than the integerated metal based singlestory building shown in Figure 2.19. 
Table 2.1: A comparison between different types of PV panels

\begin{tabular}{|c|c|c|c|c|c|}
\hline Column 1 & $\begin{array}{c}\text { Efficiency } \\
(\%)\end{array}$ & $\begin{array}{c}\text { Price } \\
(\mathbf{\$} / \mathbf{m} 2)\end{array}$ & $\begin{array}{c}\text { Lifetime } \\
\text { (years) }\end{array}$ & Reliability & $\begin{array}{c}\text { Degration } \\
(\%)\end{array}$ \\
\hline Crystalline Silicon & 13.5 & 473 & 30 & $\begin{array}{c}1 \\
\text { failure/4200 } \\
\text { mod years }\end{array}$ & 1 \\
\hline $\begin{array}{c}\text { Amorphous } \\
\text { si (window-based) }\end{array}$ & 6.5 & 215 & 30 & $\begin{array}{c}\text { not } \\
\text { available }\end{array}$ & 1.5 \\
\hline CdTe & 8.5 & 213 & 30 & $\begin{array}{c}\text { not } \\
\text { available }\end{array}$ & 2 \\
\hline
\end{tabular}

It should be noted that the costs given in Table 2.1 reflect the fact that amorphous panels are cheaper to manufacture and commonly off-the-shelf items whereas the other BIPV panels must be custom fabricated in order to be installed. They are also less affected by temperature changes. However, despite their high cost, wafer-based crystalline-silicon (c-Si) technologies have continued to show steady improvement in cost. Moreover, most crystalline-silicon module manufacturers offer warranties of 25 years, typically guaranteeing that the power output of the module will not decrease by more than $20 \%$ over a period. These warranties are due to the continuous research and development efforts in this technology, while this is not the case in the relatively new thin-film technology. Thin-films held slightly less than $10 \%$ of the market over a period of 6 years, from 1999 to 2004 (NREL, 2007). However, due to high silicon costs, the thin-film technology was able to gain additional market share in 2004 . Increasing the application of thin-film PV panels will ultimately improve the efficiency of these PV panels (NREL, 2007).

There are a number of methods commonly used to integrate PV panels into a building. In all of these configurations the PV panels are either placed on top or integrated with the roof system of a building. 


\section{Sloped glazing}
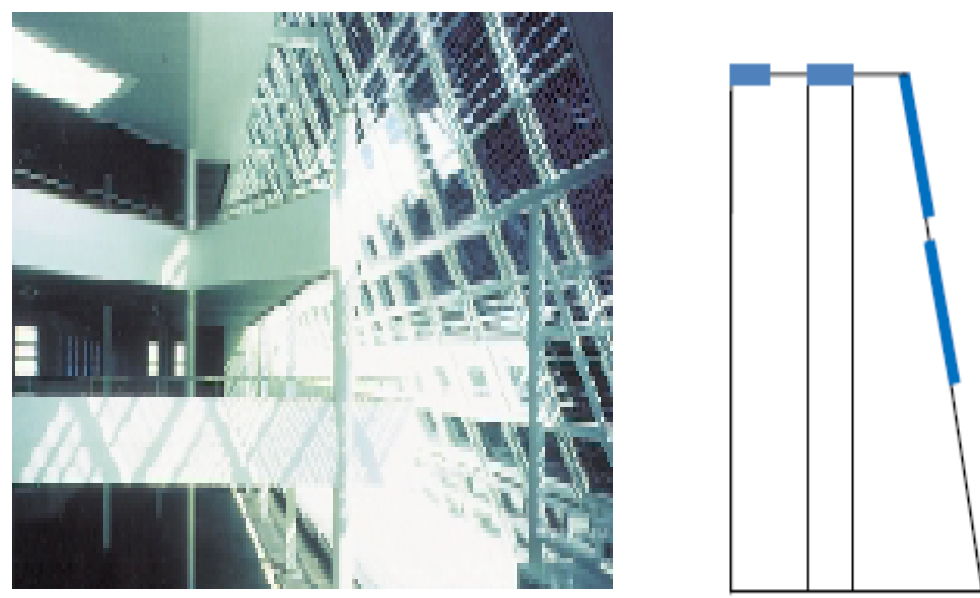

Figure 2.20: Atrium with integrated amorphous silicon PV panels in the solar office of Doxford International Park, in Sunderland, UK. This system produces $73 \mathrm{KW}$. (Thomas and Fordham, 2001).

Generally, any overhead sloped glazing, sunspaces, atriums, greenhouses, or tilted walls belong to this category. They include semi-transparent glazing systems, framed with aluminum, containing tinted, laminated glass, or plastic glazing units. Commonly, they are part of the daylighting solution of buildings. Several off-theshelf PV modules are suitable for these applications, because they are the same size and shape as tinted, laminated glazing units. Customized modules may be fabricated to a specific size, strength, transparency, color, and other criteria. PV panels mainly transmit a comfortable amount of diffused light. Diffused daylighting is typically a desired condition in office buildings while too much sunlight may cause overheating and excessive glare (Kiss and Kinkead, 1995). However, as discussed in the previous 
section, PV glazing usually has much less transparency than regular glass $(5-10 \%$ transparency). This greatly impacts the amount of daylight in the building. To optimize PV glazing and the daylight in the building, a balance should be applied to the design. The window size varies with PV system efficiency and transparency. It is suggested that the window area should be $20 \%$ of the façade area on the south orientation in the northern hemisphere in order to supply a minimum amount of daylight. According to (Olesen, 2000) this amount should increase to $24 \%$ for integrated PV systems of crystalline silicon while it would be about $32 \%$ for thinfilm PV panels.

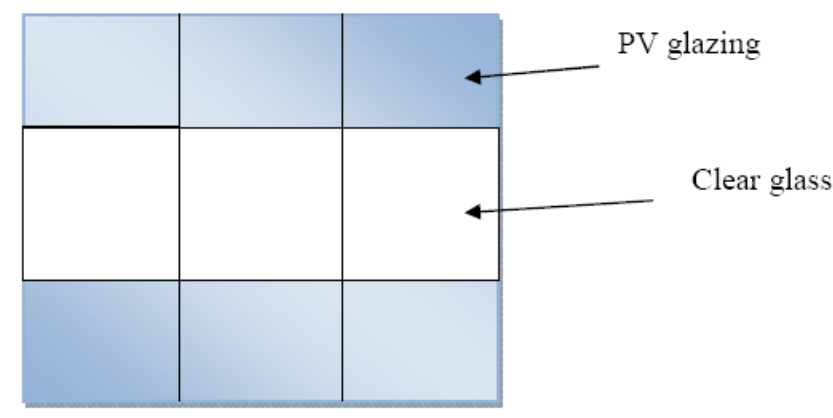

Figure 2.21: The suggested PV glazing amount in the window.

The design shown in Figure 2.21 prevents glare, because the PV glazing forms the upper and lower part of the entire unit with clear glass in between. Moreover, this configuration does not obstruct the view and daylighting because it is located in the center of the window. Figure 2.22 shows the APS Facility in California with integrated PV panels. In this office building, amorphous PV modules are combined with vision glass panels in standard curtain wall framing (Kiss and Kinkead, 1995). The PV modules are sealed at the back with an opaque insulating panel, much like 
spandrel panels in a multi-story curtain wall. As shown in the picture, PV panels could not replace the entire window. However, in Figure 2.23, PV panels are placed vertically. Vertically placed PV panels will be discussed in the next configuration. Generally, there are more examples of PV applications in atriums or sloped wall units at desired tilt and azimuth (Thomas and Fordham, 2001).

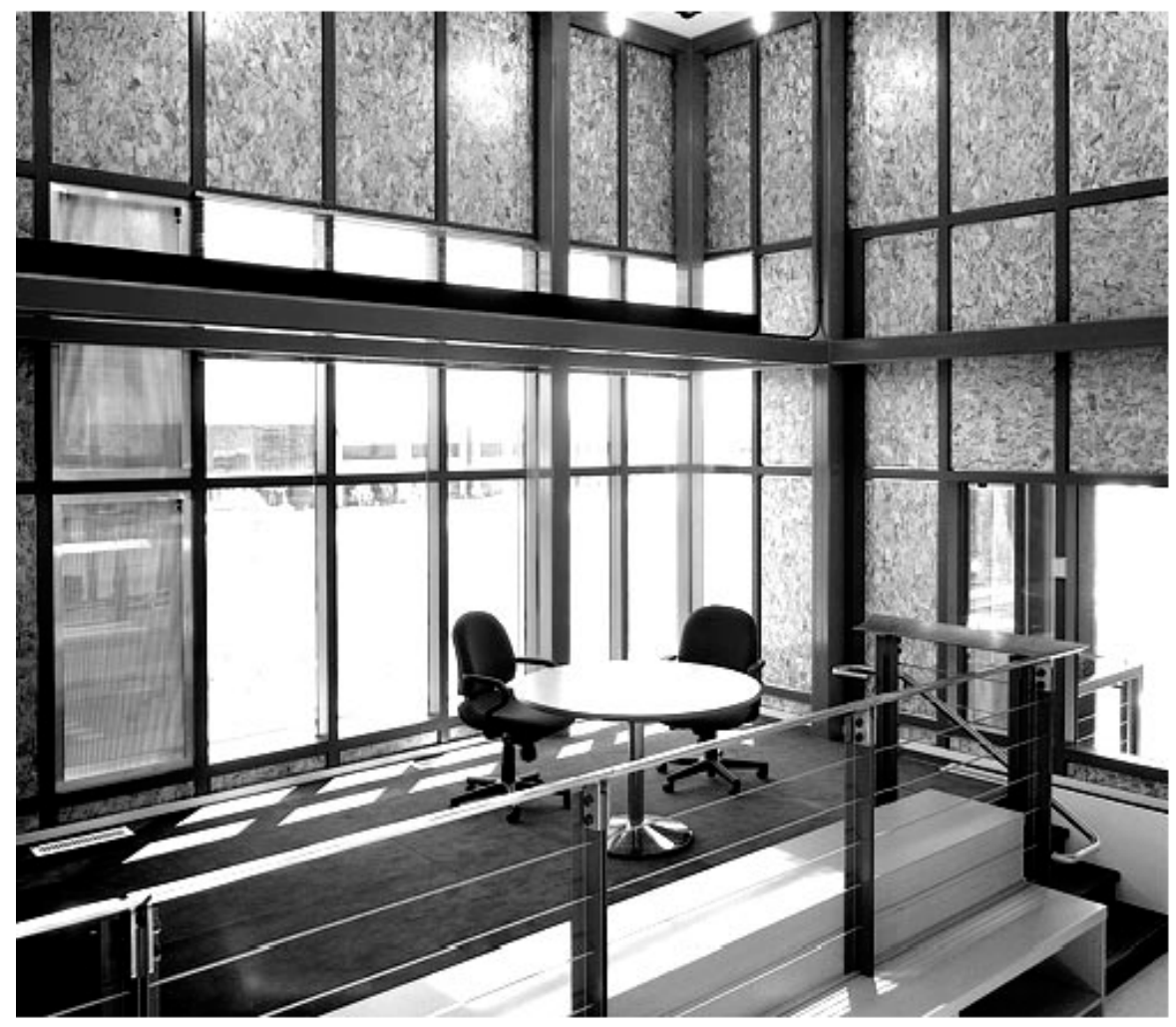

Figure 2.22: APS Facility in California, interior space 
2. Vertical panels

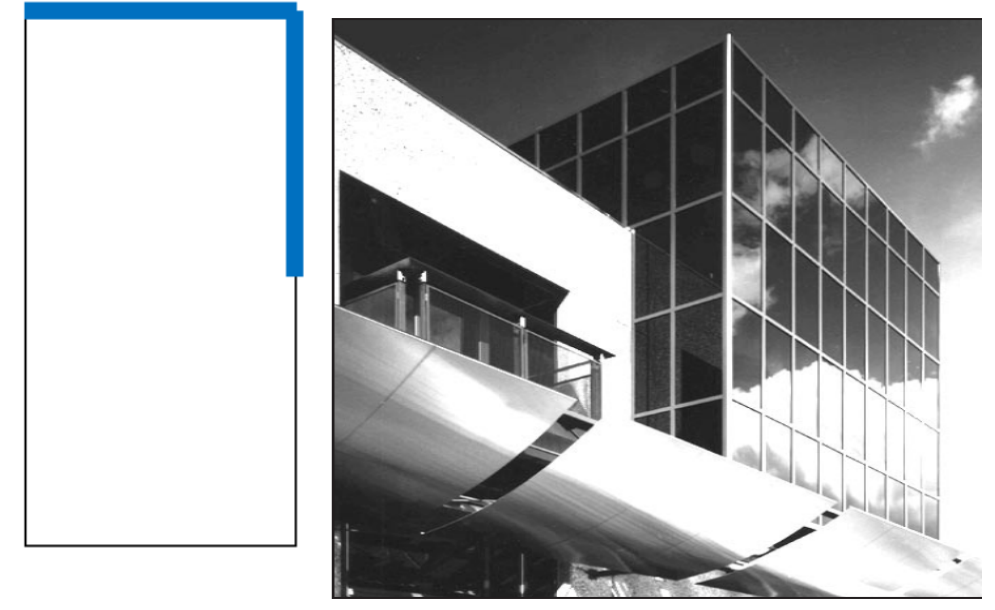

Figure 2.23: APS Office Facility in California (Kiss and Kinkead, 1995)
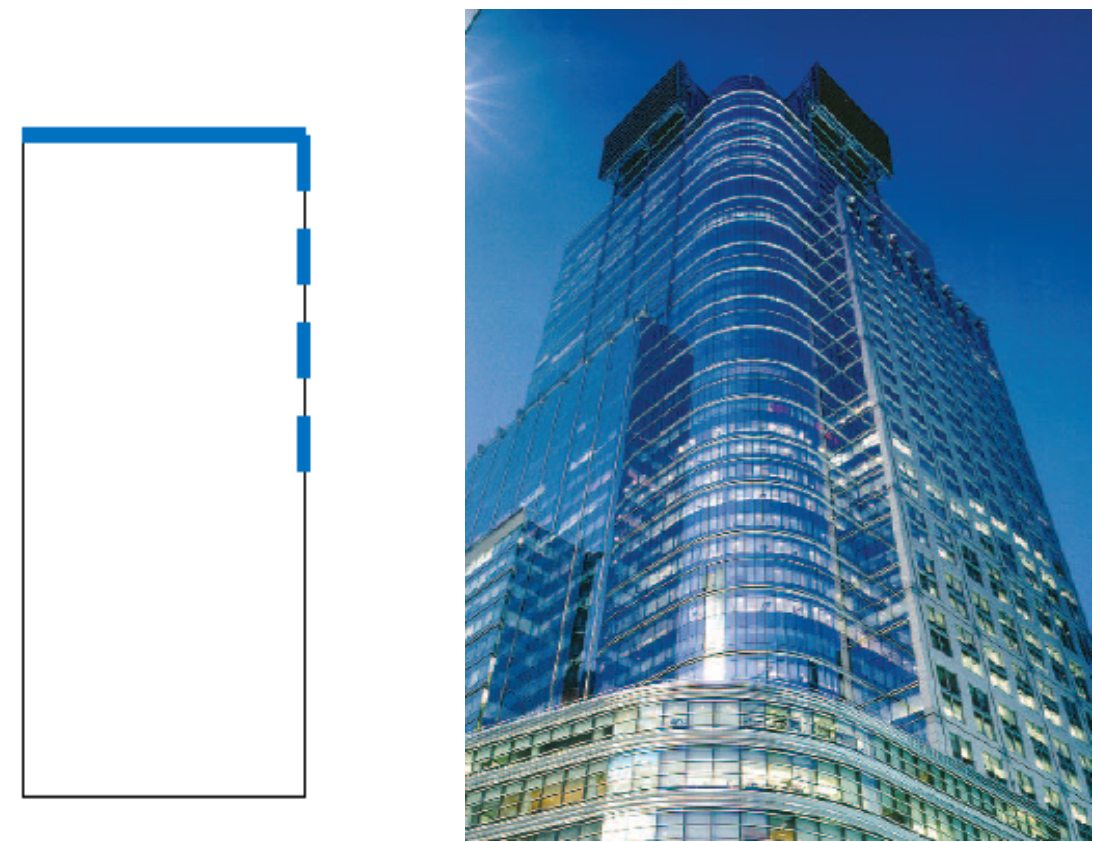

Figure 2.24: 4 Times Square, New York (NREL, 2007) 
Vertical PV panel assemblies with or without windows have the same construction characteristics as atria/sloped-glazing, but they have reduced PV output as a result of their vertical orientation. On the other hand, a wider range of PV products is suitable for curtain walls. Curtain walls in multi-story buildings typically contain opaque surfaces (spandrel areas), where non-transparent modules can also be employed. Semi-transparent PV panels with medium optical quality might be used in parts of curtain wall glazing, where daylighting is the main design objective. However, in this configuration, a few compromises must be made between glare, overheating, and the density of PV panels used in the façade.

3. Inclined walls with PV panels:

This configuration will enhance efficiency because the PV panels are tilted. However, it adds complexity to the design of the building. It might also create a degree of self-shading. Nevertheless, this type of design can employ all types of commercially availible PV panels and is not restricted to window-based technology. 


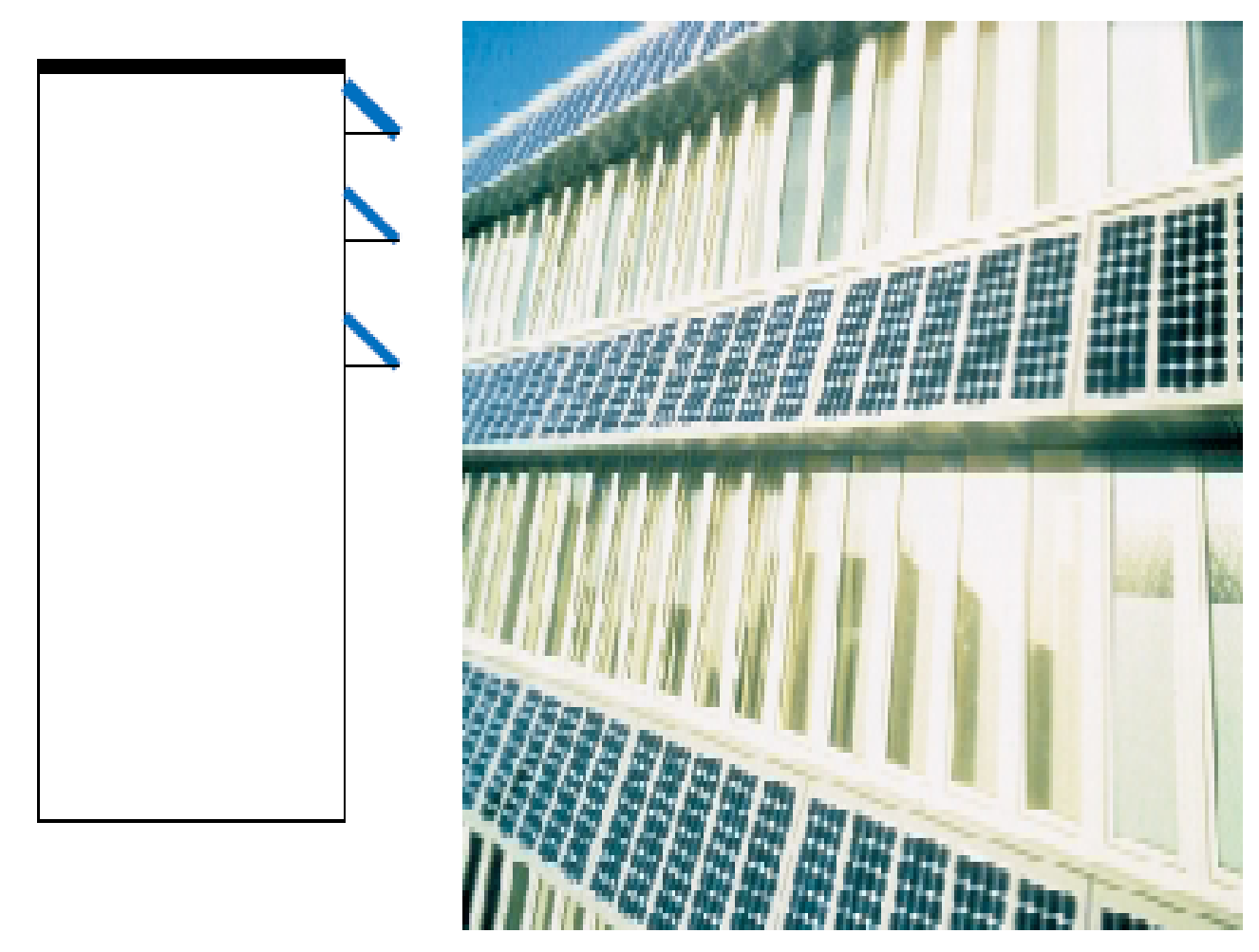

Figure 2.25: Inclined PV panels at the University of North Umbria, UK. The system was installed in 1994 (Thomas and Fordham, 2001).

Kyocera Cooperation ${ }^{1}$ has used this configuration (Figure 2.25) on their headquarters building in Japan. This building is 20 stories high. PV panels were integrated on the south wall and roof of the building. The main objective was to demonstrate the viability of large BIPV panel production for commercial office buildings. This case will be reviewed as part of case studies in Chapter 3 .

\footnotetext{
${ }^{1}$ One of the well-known BIPV manufacturers.
} 
4. Fixed sunshades
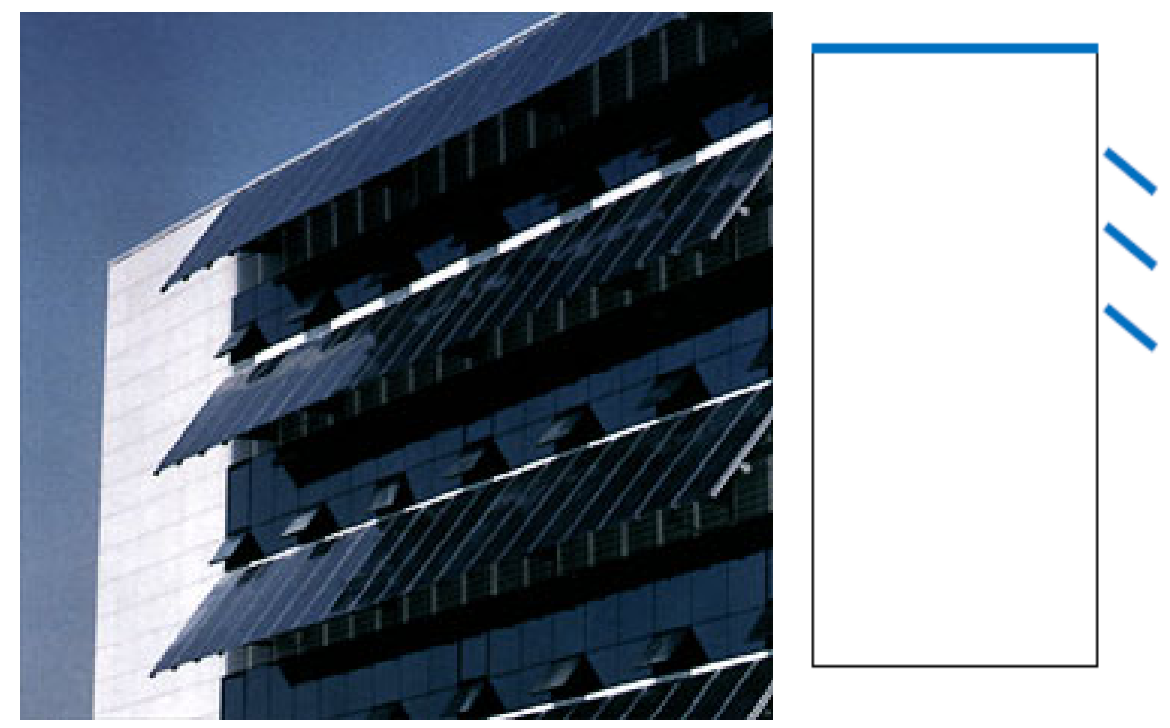

Figure 2.26: Samsung commercial office building in Seoul, Korea. A grid-connected system with $40 \mathrm{KW}$ power is integrated in fixed sunshades and the roof of the system (PV Database, 2007).

The configuration shown in Figure 2.26 can enhance shading benefits for glare reduction but it leads to a loss of daylight. The efficiency of the PV panels can be improved due to the tilt of the panels. In addition, shading elements are well suited to accommodate PV laminates, as they are oriented towards the sun (Figure 2.27), often have a flat surface, and allow rear ventilation that dissipates the generated heat to some extent. As shown in Figure 2.26, in most cases standard PV modules have been secured to the building envelope using a metal frame. In addition, construction is easier, because it is the same as installing regular sunshades on the building. However, shading from adjacent buildings or even the rest of the PV panels is expected. Similar to inclined PV panels, any kind of PV cells, including 
conventional PV panels are functional. This option provides more alternatives for designers. Maintenance is more convenient in this kind of design (Thomas and Fordham, 2001).
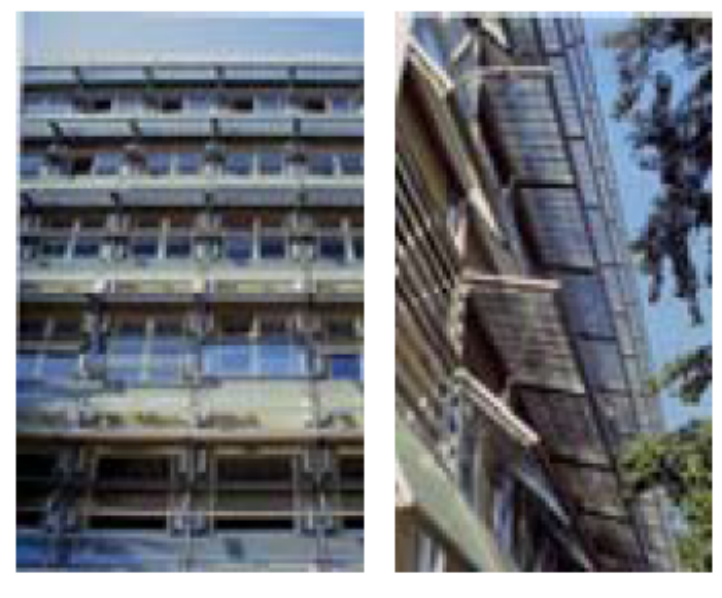

Figure 2.27: Fixed sunshades in the SUVA building. A commercial office building in Switzerland, built in 1993 (Witkopf et al., 2004).

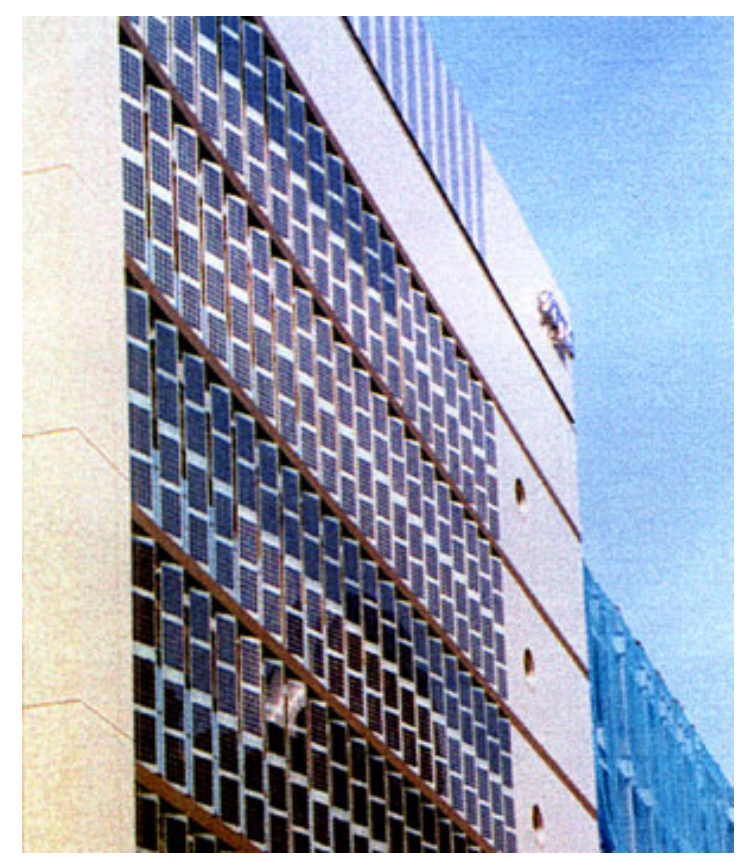

Figure 2.28: Solar wings in an office building in Switzerland with fixed BIPV louvers (PV Database, 2007) 
5. Moveable sunshades

This configuration (Figure 2.29) includes all of the advantages of fixed sunshades plus greater efficiency, because the tilt angle can be changed according to the solar radiation level either by hand or by mechanical and electrical means. Both the tilt and orientation of the PV panels can be adjusted by moving the sunshades. This results in adding more costs to the construction, however, efficiency is increased.

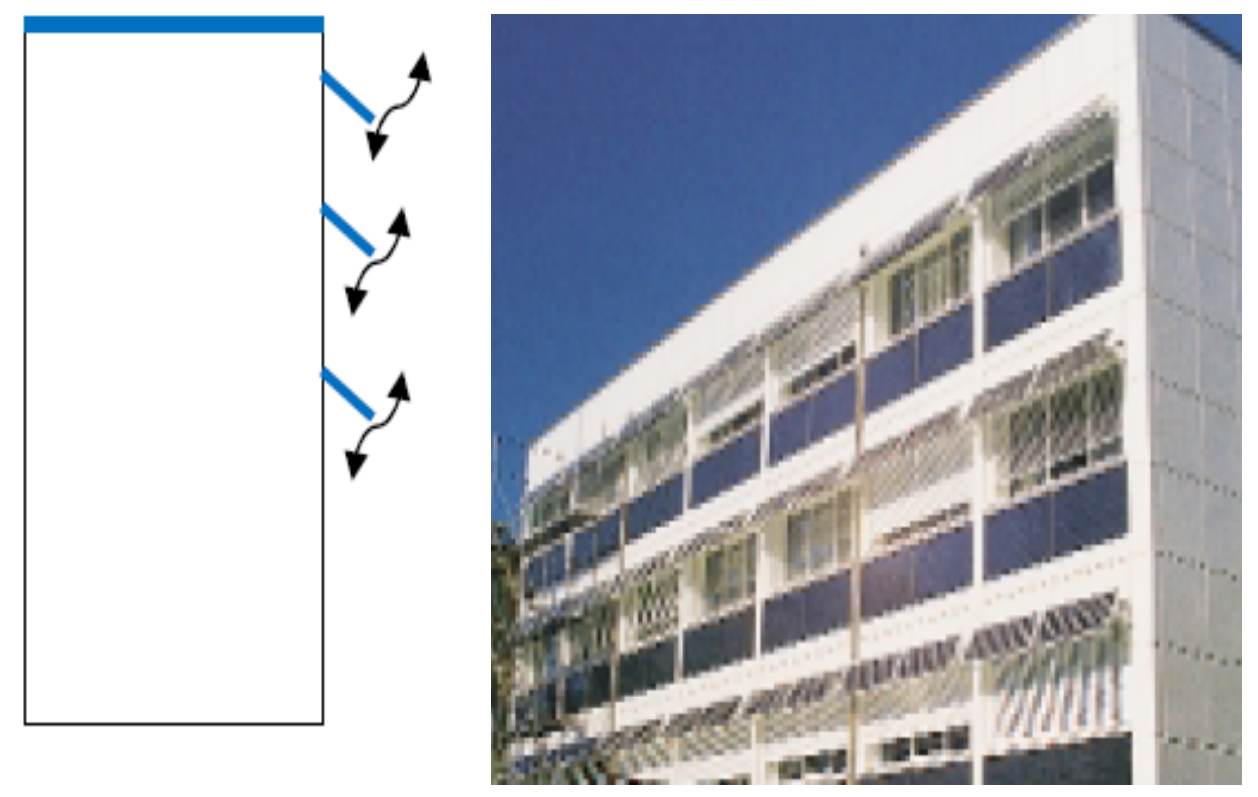

Figure 2.29: Moveable sunshades in a commercial office building, in Switzerland (Thomas and Fordham, 2001) 


\section{Chapter 3: Factors that influence the efficiency of BIPV systems}

This chapter will discuss the principal factors that influence the operational efficiency of BIPV systems in multi-story buildings. These factors include: site and location considerations; orientation; tilt angle; inverters; wiring; dirt and dust; and, shading.

\subsection{Site and location considerations:}

Location and regional climatic conditions are the primary determining factors in order to evaluate the feasibility of PV panels. They include the following factors:

- Temperature

- Amount of irradiance

- Utility rates

Generally, efficiency varies inversely with the operating temperature. However, the rate of change in efficiency differs in each type of cell. Two factors have an inverse effect on the efficiency:

As shown in Figure 3.1, open circuit voltage changes significantly as temperature increases, while the current increases slightly. In crystalline silicon cells, voltage 
drops approximately $0.37 \%$ while current increases about $0.05 \%$ for each degree Celsius increase in temperature. The ultimate result is $0.5 \%$ degradation in performance for each degree Celsius increase in maximum power. This ratio decreases in thin-film modules. The degradation factor in thin-film modules is approximately $0.21 \%$ per degree Celsius ${ }^{1}$ (King et al., 1997). For example, at the expected $50^{\circ} \mathrm{C}$ to $60^{\circ} \mathrm{C}$ cell temperature during normal operation the degradation can be calculated as follows:

$60^{\circ} \mathrm{C}-25^{\circ} \mathrm{C}=35^{\circ} \mathrm{C}$

$\left(35^{\circ} \mathrm{C} \times-.5 \% /{ }^{\circ} \mathrm{C}\right)=-17.5 \%$ for crystalline PV cells

$\left(35^{\circ} \mathrm{C} \times-.21 \% /{ }^{\circ} \mathrm{C}\right)=-7.35 \%$ for amorphous PV cells

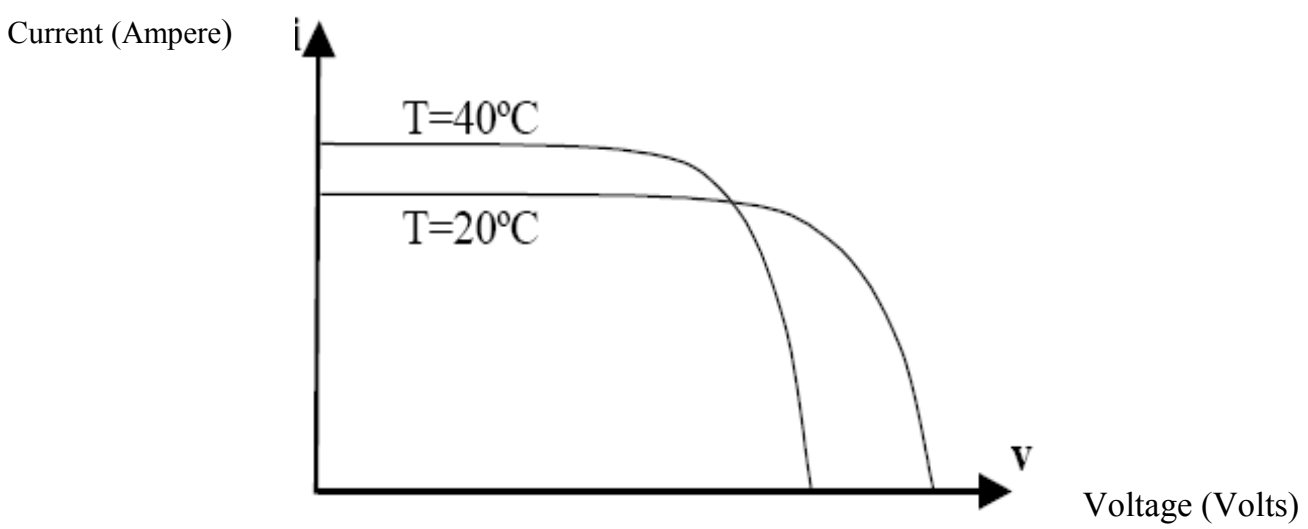

Figure 3.1: Typical I-V characteristics of a crystalline PV cell at different temperatures (Shenck, 2005)

${ }^{1}$ As temperature increases by 1 degree Celsius, the power output decreases by $0.21 \%$. 
Operating temperature depends on the site location. However, a suitable ventilation and cooling system might be useful to mitigate the temperature effect on PV cell performance. The heating issue is more critical in BIPV panels, especially in wall cladding, since interior finishes ${ }^{1}$ will normally not allow enough ventilation. Therefore, thin-film technology appears to be a more suitable alternative in this type of application even though it has a lower efficiency. It is claimed that the generated heat by PV panels can be reused for heating purposes. However, this has not been demonstrated on any project of this type. This might be based on the additional cost needed to utilize the generated heat. Basically, the capital cost of PV panels is high enough to distract the building owner from all the potential benefits of the system.

The PV cell current is directly proportional to the solar intensity. Single crystalline IV curves at different intensities are shown in Figure 3.2.

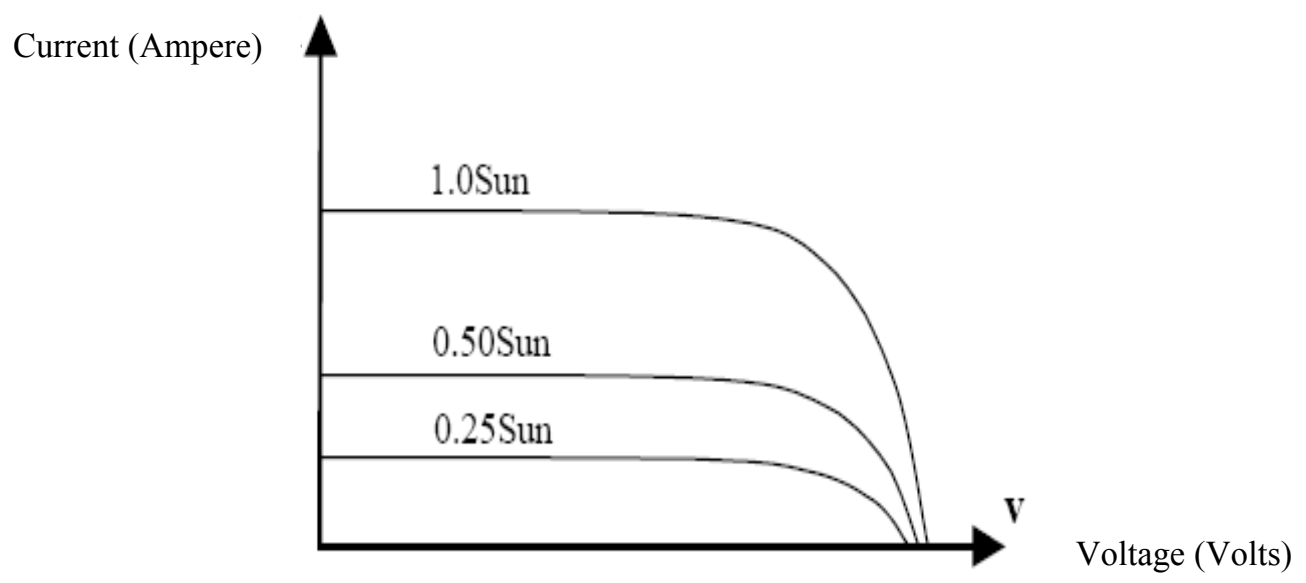

Figure 3.2: I-V characteristics at varied solar intensities (Shenck, 2005)

\footnotetext{
${ }^{1}$ Interior side of a PV panel wall is covered with drywall finishes, so it would not allow heat to be passed into the room. This problem is not applicable to glass PV panels.
} 
As stated in the previous section, normally I-V curves are drawn based on STC test conditions that set the value of AM 1.5 as a full sun condition (Figure 3.3).

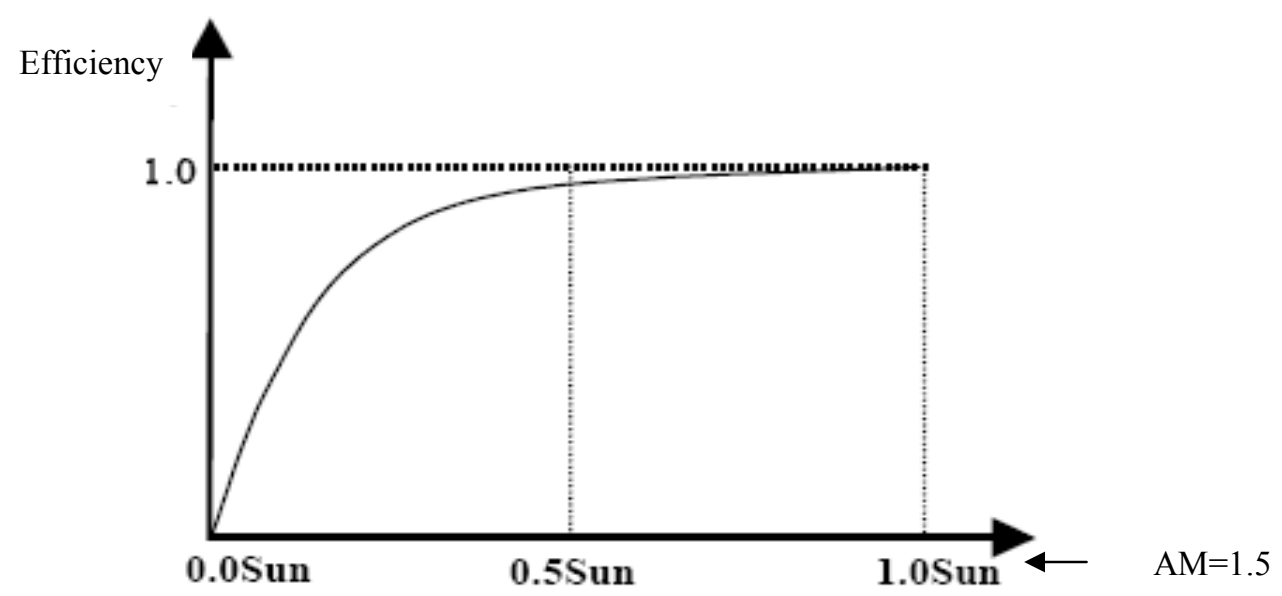

Figure 3.3: PV cell efficiency $(\eta)$ over the normalized range of insolation ${ }^{1}$

In a test performed by Electroroof ${ }^{2}$ to examine the performance of different types of PV cells, crystalline silicon panels showed more sensitivity to radiation variation than thin-film modules. However, the overall performance of crystalline PV modules was found to be steadier with higher efficiency and reliability. The majority of thinfilm modules do not show the theoretically predicted performance. This degradation is partly due to cell integration to form a module. The quality of depositing material in the thin-film cell can be another reason for the reduced output efficiency. For example, Uni-solar, one of the largest manufacturers of solar cells, produces thinfilm modules with $13 \%$ efficiency for showcases. However, the majority of their thin-film modules are rated at an efficiency of 7 to $8 \%$.

\footnotetext{
${ }^{1}$ As shown in the curve the PV cell still operates on cloudy days although the efficiency is lower ${ }^{2}$ www.Electroroof.com 


\subsection{Orientation}

Azimuth, or deviation from true south ${ }^{1}$, has a similar impact on energy production as the tilt angle. Optimum performance is typically obtained when the array is tilted and properly aligned with true south. Deviations from true south skew the peak output curves in the direction of the deviation (east or west). Tilt and orientation have a closely related impact on PV panels. Generally, the steeper the tilt angle, the greater the effect is on the deviation from true south and on the annual energy output (Gregg et al., 2003). Table 3.1 shows different orientations at the same latitude (i.e., New York City) for a $12 \mathrm{KW}$ system.

Table 3.1: New York City daily clear sky insolation

\begin{tabular}{|l|l|l|}
\hline \multicolumn{1}{|c|}{ Orientation } & Tilt (Degrees) & KWh/ yr \\
\hline South & 40 & 25000 \\
\hline SE-SW & 90 & 18000 \\
& 40 & 27000 \\
\hline North & 90 & 20000 \\
\hline \multirow{2}{*}{ East, West } & 40 & 19000 \\
& 90 & 13000 \\
& 90 & 24000 \\
\hline
\end{tabular}

\footnotetext{
${ }^{1}$ True south assigned to the exact moment of solar noon where a vertical pole casts a shadow exactly between the north and south orientation. However, solar noon should be calculated for each area based on its longitude and latitude. More information can be found on: www.srrb.noaa.gov.
} 
Based on Table 3.1, 10\% increase will occur in vertical panels by changing the orientation from south to south-east/south-west (SW/SE). This percentage changes to approximately $8 \%$ reduction for an east/west orientation. Therefore, designers naturally favor a south orientation. However, shading issues may be a significant factor. In that case, the north side would be the best alternative, but this selection brings up other problems such as low-energy considerations. North windows are limited due to heat loss and daylighting issues. South facing windows allow the winter sun in while the thermal mass stores the heat gained by sun radiation. PV panels as windows increase the window area or reduce the thermal mass, both result in loss of heat insulation. Consequently, each case should be evaluated in detail so that an optimum design, which is a compromise between all these variables, can be selected.

\subsection{Tilt:}

The main reference point is the latitude but other factors should be considered as well. The irradiance of the sun varies with the time of year. Normally, the shallow tilt angles appear to produce more energy in the summer months, while the steeper angles are more efficient in the winter months ${ }^{1}$. The optimum fixed angle is the compromise between the extremes that allow for the largest delivered energy on an annualized basis (Gregg et al., 2003). However, PV systems integrated into the

\footnotetext{
${ }^{1}$ Normally the optimum angle in the summer time is latitude- 15 , while it is latitude +15 in the winter time. 
building façade have normally a tilt of $90^{\circ}$. In order to evaluate the effect of tilt variation, Table 3.2 is provided by NREL: This table shows variation of irradiance ${ }^{1}$ over seasonal change.

Table 3.2: New York City, NY: Latitude $40.78^{\circ} \mathrm{N}$, south orientation, average daily sun hours, $\mathrm{KWh} / \mathrm{m}^{2}$

\begin{tabular}{|c|c|c|c|c|c|c|c|c|c|c|c|c|c|}
\hline Tilt & Jan & Feb & Mar & Apr & May & June & July & Aug & Sept & Oct & Nov & Dec & year \\
\hline Lat-15 & 2.9 & 3.7 & 4.6 & 5.3 & 5.8 & 6.0 & 6.0 & 5.7 & 5.0 & 4.1 & 2.9 & 2.4 & 4.5 \\
\hline Lat & 3.2 & 4.0 & 4.8 & 5.2 & 5.4 & 5.5 & 5.6 & 5.5 & 5.0 & 4.4 & 3.2 & 2.8 & 4.6 \\
\hline Lat+15 & 3.4 & 4.1 & 4.6 & 4.8 & 4.8 & 4.8 & 4.9 & 5.0 & 4.8 & 4.4 & 3.3 & 3.0 & 4.3 \\
\hline Vertical & 3.2 & 3.6 & 3.5 & 3.1 & 2.6 & 2.6 & 2.7 & 3.0 & 3.4 & 3.6 & 3.0 & 2.7 & 3.1 \\
\hline Horizontal & 1.7 & 2.5 & 3.5 & 4.5 & 5.4 & 5.9 & 5.9 & 5.2 & 4.1 & 2.8 & 1.7 & 1.4 & 3.7 \\
\hline Temp (c) & 3.1 & 4.7 & 10.0 & 16.2 & 22.1 & 26.7 & 29.6 & 28.7 & 24.6 & 18.5 & 12.2 & 5.8 & 16.8 \\
\hline
\end{tabular}

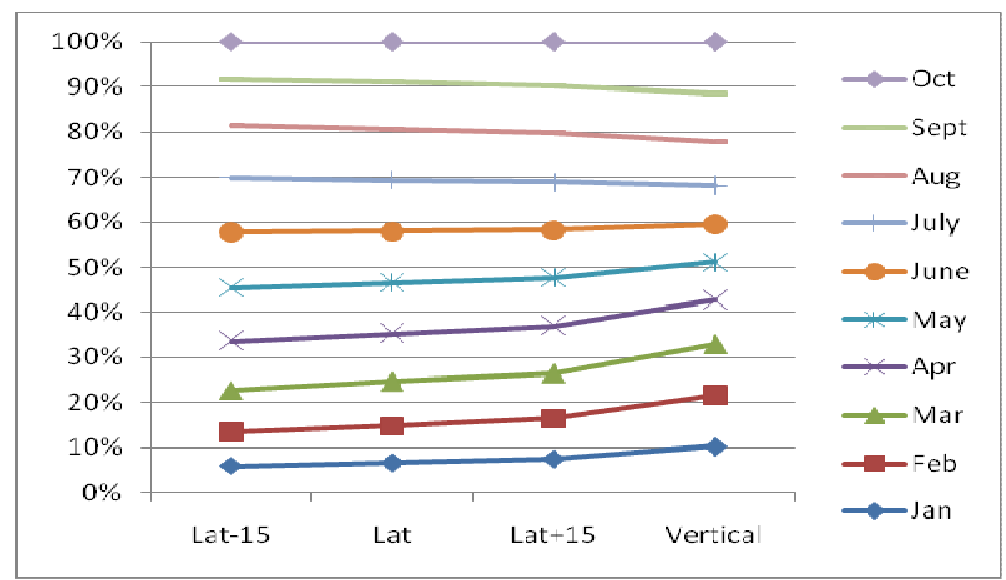

Figure 3.5: The irradiation variations at different latitudes

\footnotetext{
${ }^{1}$ Irradiance represents the number of available peak sun hours during the day.
} 


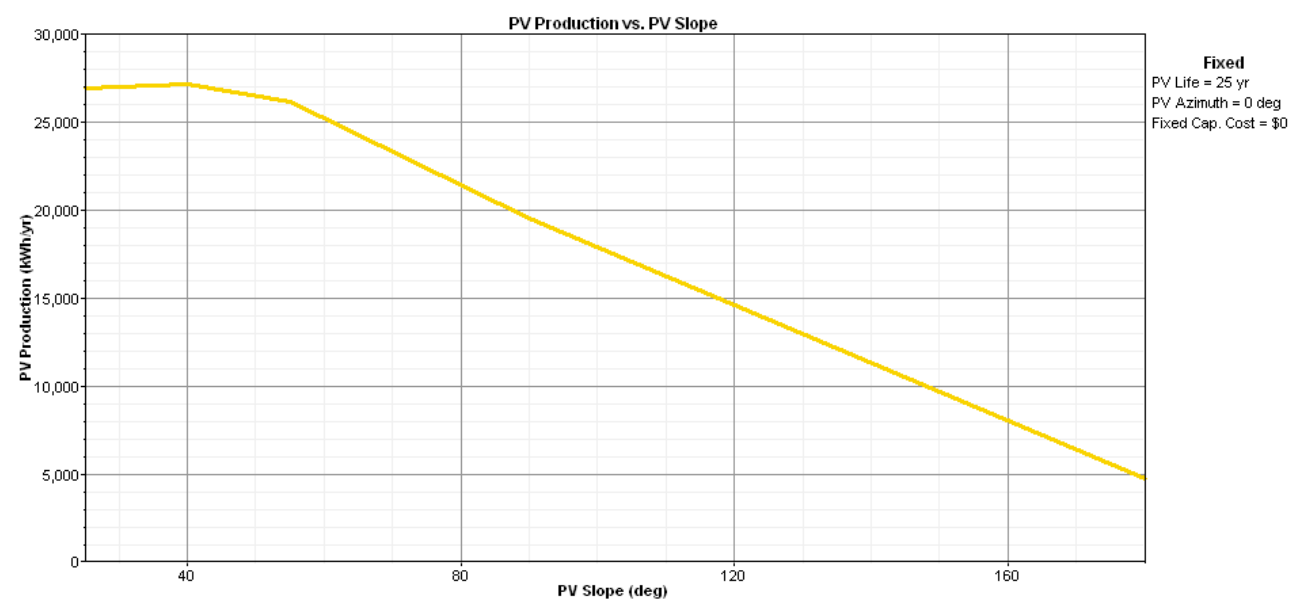

Figure 3.6: PV production vs. the tilt angle

As shown in Table 3.2, there is a minor difference in irradiation during winter and fall, but the difference can be significant in summer. The overall yearly output shows that PV panels placed with the tilt angle equal to the latitude $\left(40^{\circ}\right)$ have a $28 \%$ higher efficiency compared with $90^{\circ}$ installed panels. However, this factor is not the same throughout the whole year. Nevertheless, the tilt angle is also propotional to the amount of diffused sunlight, because diffused radiation is less direction dependent. For example, in areas with half sun conditions the tilt effectiveness will be reduced. Figure 3.6 shows PV production related to each tilt angle. In this figure, the maximum PV production output occurs at 40 degrees, which is equal to the latitude for that region. The difference between the optimum angle (40 degrees) and vertical panel production is about $6000 \mathrm{KWh} / \mathrm{yr}$, which is not a negligible amount. 
Table 3.3 (Reygadas et al., 2000) is another example of irridiation varition for each season. Data were derived for 52 degrees $(37+15)$ and 22 dgrees $(37-15)$. The optimum angle is derived for each season. Angles close to 50 degrees operate more efficiently, while more radition can be obtained with angles close to 30 degrees in the summer months.

Table 3.3: Insolation in Sacramento, CA (Latitude 37 degrees)

\begin{tabular}{lrrrrrrrrrrrrr}
\hline & Jan & Feb & Mar & Apr & May & Jun & Jul & Aug & Sep & Oct & Nov & Dec $\begin{array}{l}\text { Annual } \\
\text { Average }\end{array}$ \\
\hline $\begin{array}{l}\text { Solar } \\
\text { insolation }\end{array}$ & 2.49 & 3.49 & 4.5 & 6 & 6.47 & 6.96 & 6.84 & 5.88 & 5.27 & 3.81 & 2.79 & 2.2 & 4.74 \\
Tilt 0 & 2.46 & 3.36 & 4.45 & 5.97 & 6.7 & 6.91 & 6.79 & 5.85 & 5.19 & 3.78 & 2.75 & 2.18 & 4.7 \\
Tilt 22 & 3.45 & 4.29 & 5.1 & 6.28 & 6.62 & 6.64 & 6.61 & 5.97 & 5.79 & 4.63 & 3.77 & 3.15 & 5.19 \\
Tilt 37 & 3.9 & 4.65 & 5.23 & 6.1 & 6.15 & 6.05 & 6.08 & 5.69 & 5.83 & 4.92 & 4.22 & 3.6 & 5.2 \\
Tilt 52 & 4.13 & 4.75 & 5.08 & 5.61 & 5.39 & 5.18 & 5.25 & 5.13 & 5.57 & 4.95 & 4.43 & 3.85 & 4.94 \\
Tilt 90 & 3.67 & 3.86 & 3.63 & 3.35 & 2.78 & 2.52 & 2.61 & 2.92 & 3.72 & 3.88 & 3.86 & 3.5 & 3.36 \\
Opt & 4.16 & 4.75 & 5.23 & 6.28 & 6.76 & 6.91 & 6.82 & 6 & 5.85 & 4.97 & 4.45 & 3.89 & 5.51 \\
Opt angle & 59 & 50 & 37 & 21 & 8 & 3 & 5 & 15 & 32 & 46 & 57 & 61 & 32.8 \\
\hline
\end{tabular}

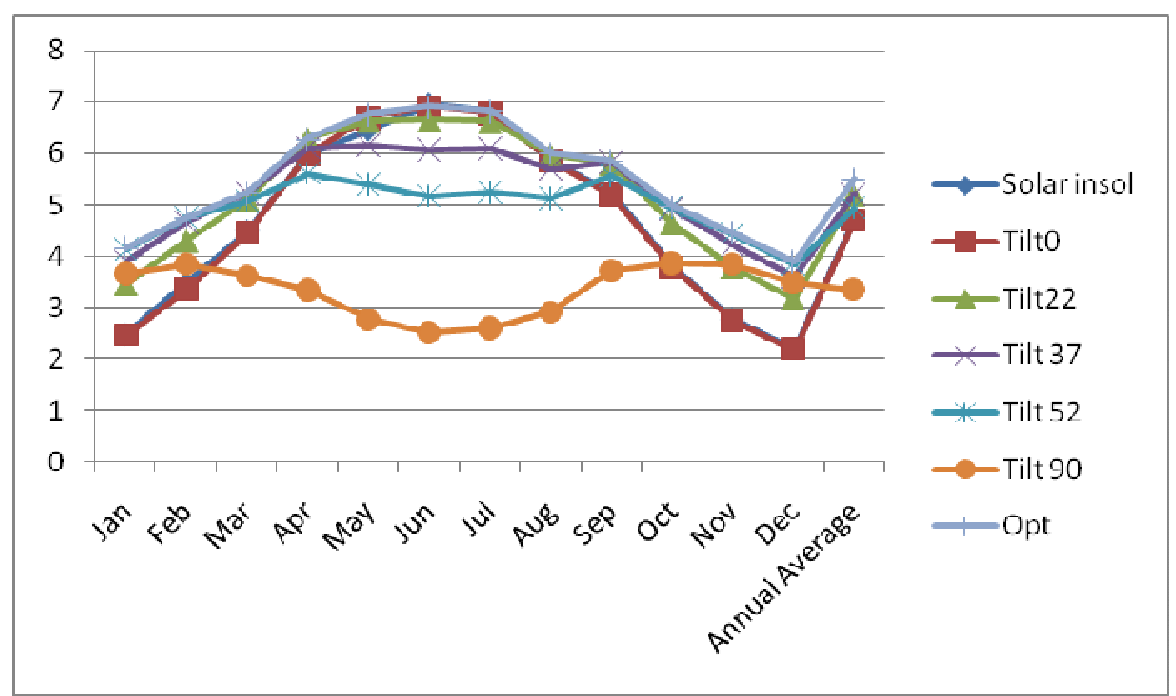

Figure 3.7: Monthly radiation vs tilt angle (Reygadas et al., 2000)

Figure 3.7 shows monthly radiation vs. tilt angle. The orange line represents the worst-case scenario that occurs in the month of December. 


\subsection{Inverters:}

Inverter selection is normally based on the load waveform and nominal efficiency. Despite the fact that generally DC to AC inverters are high performance electrical equipment, they never reach $100 \%$ efficiency. They reach their optimum performance in the range of $85-96 \%$ efficiency for power values close to the nominal rating. Based on prior discussions, distributed or centralized configurations are the most common ways to place inverters in the system. Inverters configured in a distributed strategy appear to have fewer losses and higher reliability. Failure of one distributed inverter does not stop the operation of the entire BIPV system, because they operate separately. However, this strategy may not be the best economical alternative. In fact, inverters are the next most expensive equipment after PV panels, thus semi-centralized arrangements may be a suitable alternative. Semicentralization is a compromised solution, which deploys a larger number of inverters. However, each single module is not equipped with its own inverter. Typically, in this case, a factor of 0.9 would be considered to cover the inverter efficiency loss (Kiss and Kinkead, 1995; San Diego Study Group, 2005).

\subsection{Wiring and mismatch:}

The wire length needs to be determined according to the expected currents to limit the voltage drop to less than 3\% (Gregg and et al., 2003). Therefore, due to losses during cabling, resistance of wires usually adds a factor of 0.97 to the output efficiency. Mismatch will occur in a series of cells that do not have the same I-V 
characteristics. In this case, the output of cells in series will be less than the expected output. In most cases, to minimize mismatches, manufactures produce a batch of cells and place the same batch in a module. A factor of 0.95 is commonly considered for both situations (San Diego Study Group, 2005).

\subsection{Dirt and dust:}

These factors reduce the efficiency by about $7 \%$ to $25 \%$ (San Diego Study Group, 2005; PG\&E, 2007). Rain and cleaning may help reduce dust buildup, however, a typical annual dust reduction factor is 0.93 ( $7 \%$ derating). Dirt and dust can accumulate on the solar module surface, blocking some of the sunlight and reducing the output. The amount of dust and dirt on PV panels is the same as regular glass. Dust and dirt are commonly associated with the environmental location of the PV panel installation. Consequently industrial, commercial, agricultural, and urban areas are more subject to the dirt and dust effect. Furthermore, snow cover will also result in losses in PV systems. This factor must be considered while evaluating a site prior to the design of a PV system (Gregg et.al, 2003).

\subsection{Shading:}

Shading has a major effect on the performance of PV panels. Shading appears to be more common in multi-story buildings because they are mainly located in urban areas surrounded by tall buildings. Since, solar cells are in series, minor shading can cause a major problem. Thus, shading from adjacent buildings, landscapes or even the PV cells themselves must be avoided. The following example shows how 
shading can have a severe effect on PV cell performance. A 36-cell PV module, with an output power of $40 \mathrm{~W}$, can produce only $10 \mathrm{~W}$ if one cell is fully shaded. Manufacturers mitigate the effect of shading by adding a bypass diode across each cell. The bypass diode helps to block the current from the shaded cell ${ }^{1}$. However, it is not practical to place one bypass diode across each cell. Therefore, manufacturers include at least one or two bypass diodes for the entire module. The same method can be applied when PV cells are in parallel with blocking diodes that block current flow (Shenck, 2005).

Figure 3.8 shows the summary of losses that occur during PV system operation:

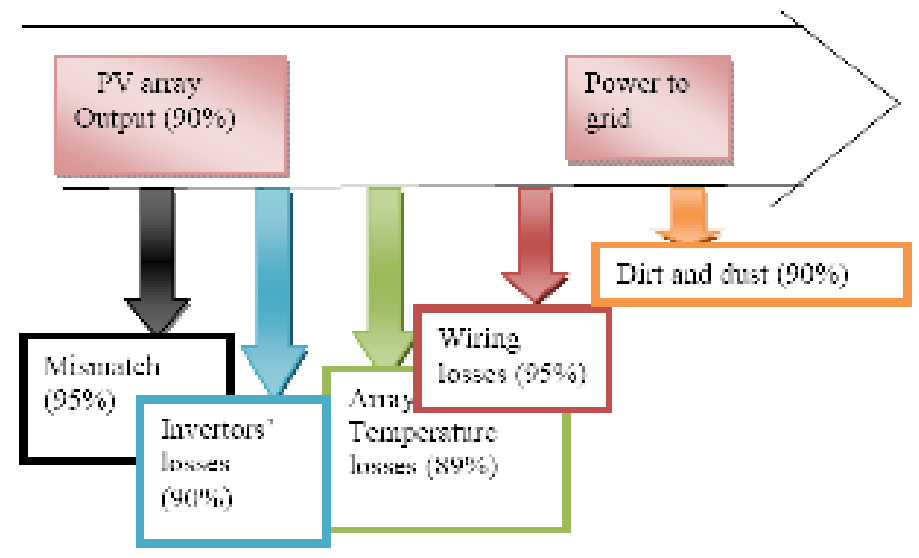

Figure 3.8: Performance losses in a PV system

Consequently, a module with 100 watts output produces approximately 58 watts.

$(100$ watts $) \times 0.95 \times 0.90 \times 0.89 \times 0.95 \times 0.90=58.55$ watts

\footnotetext{
${ }^{1}$ It operates as if the shaded cell does not exist.
} 
This combination of factors reduces the efficiency by more than $40 \%$. In combination with the relatively high cost of PV panels this performance liability does not appear to qualify the use of PV panels as a primary source of energy in multi-story buildings. However, despite the early conclusion, the author considered it of value to complete the detailed analysis presented in the following chapters. 


\section{Chapter 4: Study model analysis}

To determine the feasibility of PV panel installations for multi-story buildings, a study model is presented and parameters that impact PV panel performance are evaluated.

The study model is based on a 20-story building with a square floor plan. The building's dimensions and its surroundings are shown in Figures 4.1, 4.2, and 4.3. The first step is to calculate the area of PV panels required based on the energy consumption of the building. To obtain this information, the operational office hours and occupancy of the building must be considered. For the purpose of this base case, it is assumed that PV panels are installed on all external surfaces of the building. The variables in the base case are listed below:

1. Amount of solar radiation available

2. Influence of projected shadowing from adjacent buildings

3. Temperature

4. Type of PV panels

5. Efficiency of PV panels

6. Orientation and tilt of PV panels 


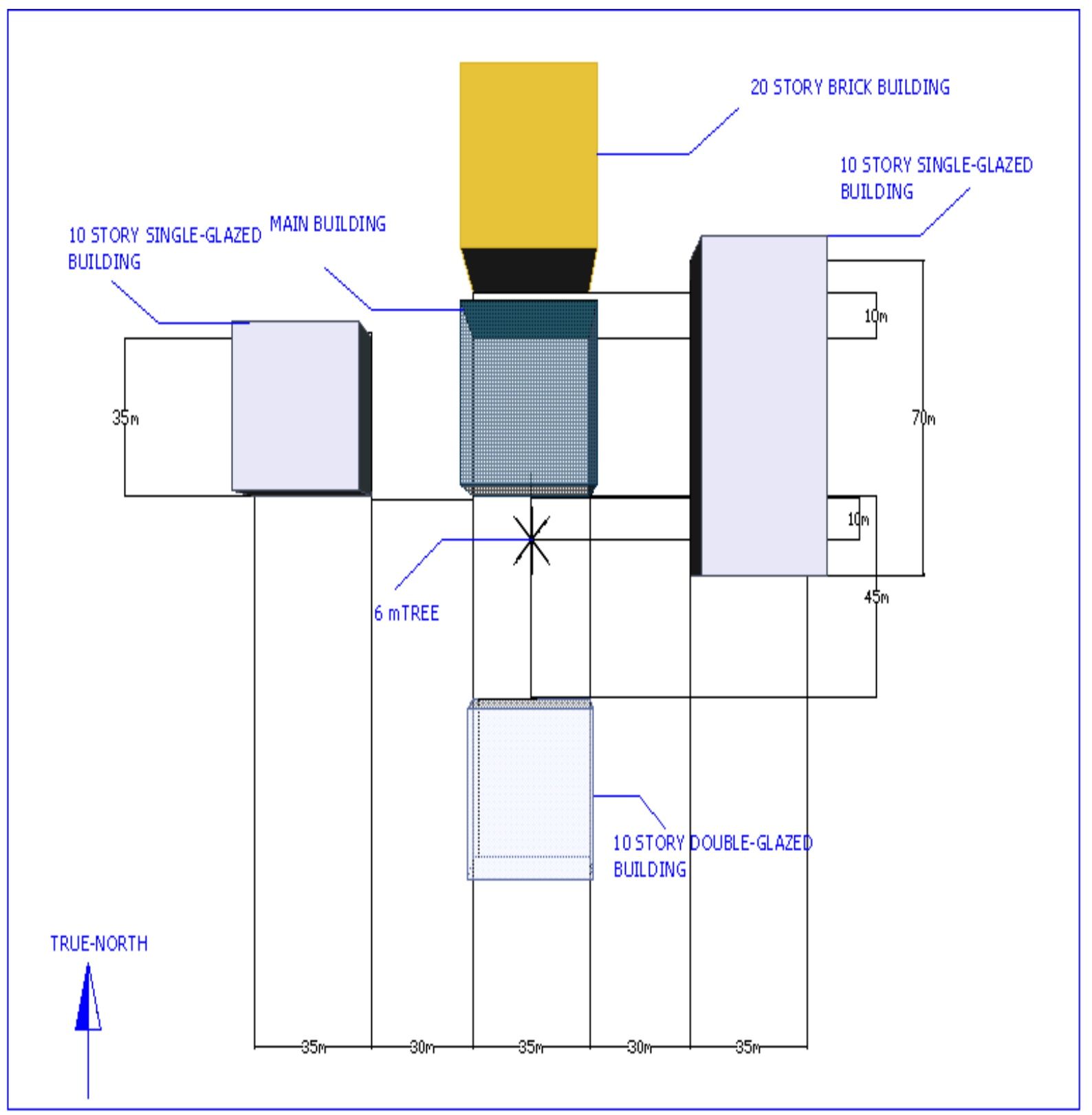

Figure 4.1: The top view of the study model 


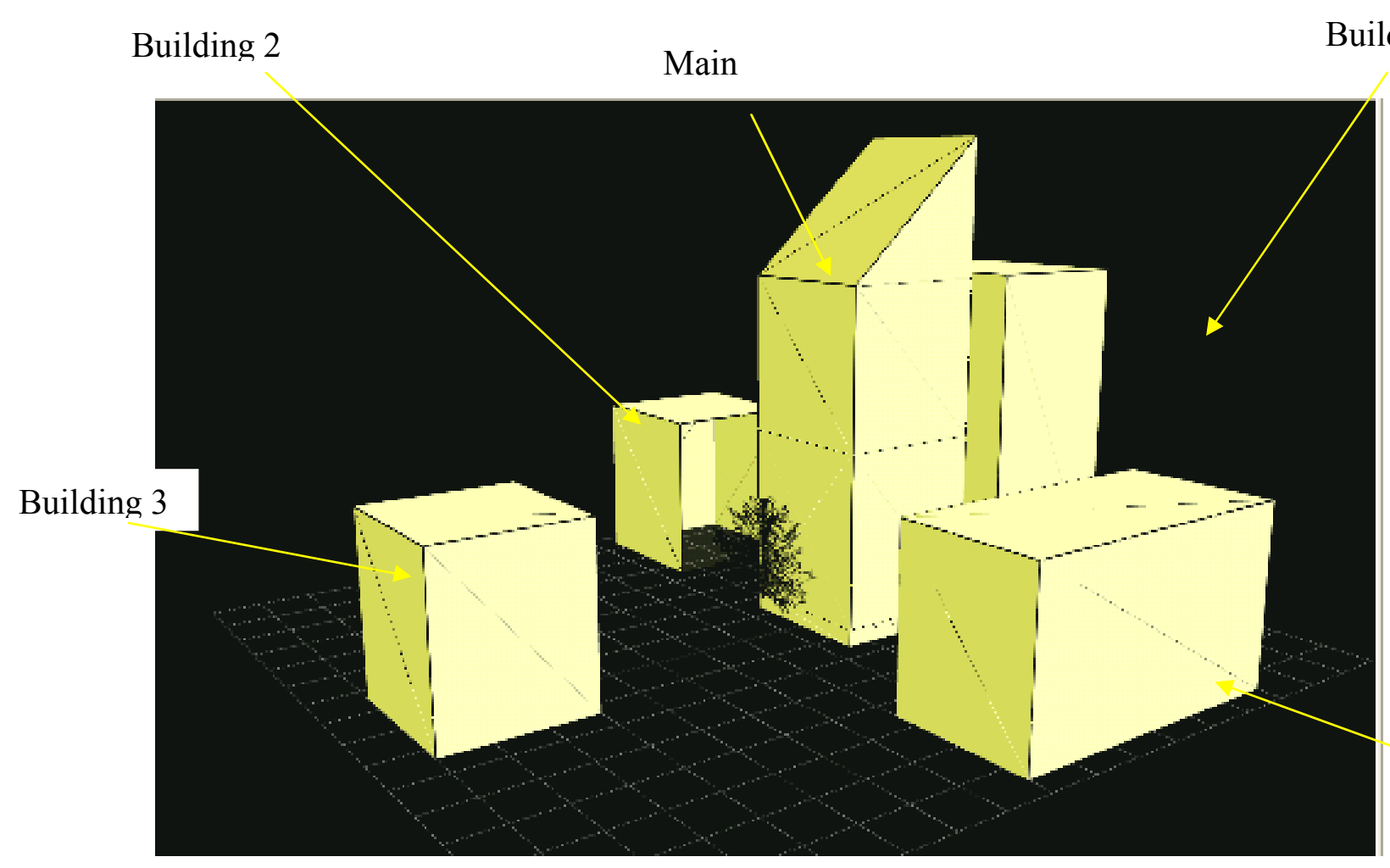

Building 4

Figure 4.2: Isometric view of the study model (adjacent buildings are identified)

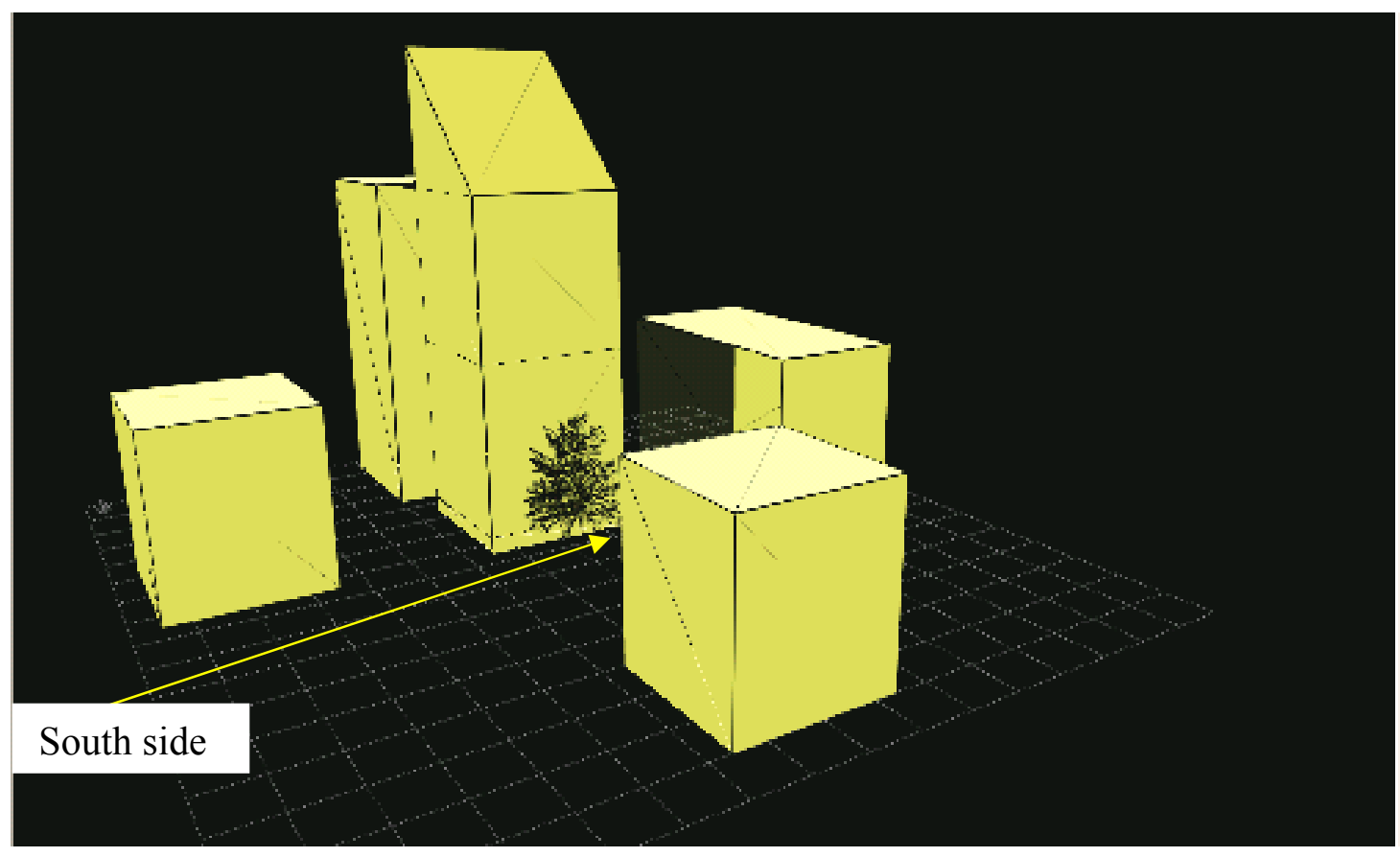

Figure 4.3: Isometric view of the study model (the tree is located on the south side, the building is oriented north-south) 


\section{$4.1 \quad$ Assumptions}

The building profile and its surroundings are presented in Table 4.1.

Table 4.1: Study model building and its surroundings

\begin{tabular}{|c|c|}
\hline Location & $\begin{array}{l}\text { The building is located in New York City at latitude } 40.78^{\circ} \mathrm{N} \\
\text { and average radiation value of } 3.1 \mathrm{~kW} \text { per square meters } \\
\text { (i.e., } 3.1 \mathrm{KW} / \mathrm{m}^{2} \text { ) over a year. The mean temperature is } \\
\text { approximately } 16.8^{\circ} \mathrm{C} \text {; average snowfall is } 102 \text { centimeters. }\end{array}$ \\
\hline Building type & $\begin{array}{l}\text { Office building, } 20 \text { stories above ground ( } 70 \mathrm{~m} \text { tall; adjacent } \\
\text { tree is } 6 \mathrm{~m} \text { tall) }\end{array}$ \\
\hline \multirow[t]{6}{*}{$\begin{array}{l}\text { Dimensions } \\
\text { and heights }\end{array}$} & $30 \mathrm{~m} \times 30 \mathrm{~m}$ (square); floor-to-floor $=3.5 \mathrm{~m}$ \\
\hline & Street surface: asphalt ( $10 \%$ reflectivity) \\
\hline & $\begin{array}{l}\text { Building 1: a } 20 \text {-story (70m) brick building } \\
\text { Reflectance: } 20 \% \text {, U-value: } 1.6 \mathrm{~W} / \mathrm{m}^{2}\end{array}$ \\
\hline & $\begin{array}{l}\text { Building 2: reflective single glazing ( } U \text {-value: } 5.7 \mathrm{~W} / \mathrm{m}^{2} \\
\text { reflectance: } 25 \%)\end{array}$ \\
\hline & $\begin{array}{l}\text { Building 3: reflective single glazing (U-value: } 5.7 \mathrm{~W} / \mathrm{m}^{2} \\
\text { reflectance: } 15 \%)\end{array}$ \\
\hline & $\begin{array}{l}\text { Building 4: low-e double glazing (light reflectance: } 16 \%, U- \\
\text { Value }=1.9 \mathrm{~W} / \mathrm{m}^{2} \text { ) }\end{array}$ \\
\hline
\end{tabular}

Analyses to be undertaken, including associated parameters to determine the feasibility of the PV system include the following:

1. A study of the projected shadowing of the adjacent buildings.

a. Distances between the main building and adjacent buildings: Three different distances are presented in this model (10m, 30m, and 45m). The presented distances affect the shadowing pattern and the amount of radiation that strikes the base case study model. 
b. Date and time of day: Shadow patterns and amount of solar radiation are all associated with the time of year and position of the sun in the sky. These parameters were calculated with the aid of the Ecotect software (www.square1.com , 2004).

c. Amount of direct and diffused sunlight.

i. Diffused sunlight: This parameter is based on an overcast sky, reflection of the ground, and reflected radiation of the adjacent buildings: The amount of reflection is determined by the external façade materials of the buildings and the floor area (www.nrel.gov , 2007).

ii. Direct sunshine: This parameter is determined by the amount of radiation at a particular time of day and day of year (www.nrel.gov, 2007). The façade area of each building is presented with a single material type. In other words, only the external materials and their U-values are considered.

d. The dimensions and geometry of the building and adjacent buildings: These parameters affect the amount of radiation and the shadow patterns. The main building has a square floor plan. Figures 4.1, 4.2, and 4.3, show four different sizes on each side of the main building. 
e. The tilt and orientation of the building: The building is oriented toward true south. The roof tilt is equal to the latitude of New York City (41 degrees).

2. A study of the PV efficiency and electricity production for this building: All parameters in item (1) affect the production of PV panels along with additional parameters such as type, orientation, and balance of the system, as specified in Chapters 2 and 3 (literature review sections). These parameters are all considered in calculating the loss, production, and efficiency of the study model.

a. Amount of radiation: This parameter, which is derived from the above calculations, affects the PV production and efficiency.

b. Amount of shading and obstruction, which is derived from the above calculations, affects the PV production and efficiency.

c. Type, technology, and efficiency of the PV panels. Two different window-based PV panels are considered.

1. Single crystalline PV panels, $130 \mathrm{~W}$ modules $(142.2$ cm by $65.3 \mathrm{~cm}), 12 \%$ efficiency in $\mathrm{STC}^{1}$.

${ }^{1} \rho(\mathrm{d}$ factor $)=0.5 \% *\left(\mathrm{t}_{1}-\mathrm{t}_{2}\right)$ Crystalline, where $\mathrm{t}_{1}$ is $25 \mathrm{C}$ and $\mathrm{t}_{2}$ is the temperature of the location. (King, Kratochvil and Boyson, 1997; Homer, 2007) 
2. Thin-film PV panels, $40 \mathrm{~W}$ modules $(156.2 \mathrm{~cm}$ by $63.5 \mathrm{~cm}), 8 \%$ efficiency in $\mathrm{STC}^{1}$.

These efficiencies vary together with factors that vary by time of year, such as temperature and radiation.

d. The tilt and orientation of PV panels: PV panels are placed vertically on the façade areas and tilted on the roof. This tilt is equal to the latitude (41 degrees).

e. Type of inverters: The inverter considered in this study model is a Xantrec, 24-44 VDC. This inverter is selected based on the PV panel's voltage.

f. Wiring of the system: cables and connectors ${ }^{2}$ considered in this study model include the regular NEC approved electrical cables and conduits required for assembling a functional PV system.

g. Balance of the system: the balance of the system includes MPPT, charge controllers, circuit breakers.

${ }^{1} \rho(\mathrm{d}$ factor $)=0.21 \% *\left(\mathrm{t}_{1}-\mathrm{t}_{2}\right)$ Thin-film, where $\mathrm{t}_{1}$ is 25 Degrees Centigrade and $\mathrm{t}_{2}$ is the temperature of the location. (King, Kratochvil and Boyson, 1997; Homer 2007)

${ }^{2} \rho(\mathrm{d}$ factor $)=5 \%$ mismatching $+10 \%$ dust (PG\&E Seminar, 2007). 
3. Economic analysis of the building.

Factors include the location parameters as well as the costs of different types of PV panels. These parameters are used to determine the overall cost of the PV system.

a. Cost of electricity: This parameter includes the off-peak and peak costs of electricity plus the demand charge and connectivity costs. These data were derived from the New York utility database (NYSERDA DG CHP integrated database system, 2008).

- Off-peak: $\$ 0.09$ per KWh

- Peak: $\$ 0.12$ per KWh

- Connectivity costs: $\$ 75$

- Demand Charge: $\$ 10 / \mathrm{KW}$ per month (NYSERDA DG/CHP Integrated Database System, 2008)

b. Cost of PV panels.

This item includes the cost of PV panels and their mounting costs.

- Single crystalline PV panels, $\$ 4.40 / \mathrm{m}^{2}, 130 \mathrm{~W}$ modules (142.2 $\mathrm{cm}$ by $65.3 \mathrm{~cm})$.

- Thin-film PV panels, $\$ 3.6 / \mathrm{m}^{2}, 40 \mathrm{~W}$ modules $(156.2 \mathrm{~cm}$ by $63.5 \mathrm{~cm})$.

- Mounting costs include cost of engineering and installation. Union labor at $\$ 40$ per hour, engineering at 
$\$ 100$ per hour (www.nrel.gov, 2007) were considered in this study model.

The variable parameters considered to derive the life cycle cost analysis of PV panels include: An interest rate of $6 \%$ (www.nrel.gov, 2007); project lifetime of 25 years (PV panel lifetime) (www.global.kyocera.com, 2007); cost of operation and maintenance $(\mathrm{O} \& \mathrm{M})$ costs (www.nrel.gov, 2007).

The objective of this chapter is to evaluate the configurations outlined in the following section.

\subsection{Configurations}

1. Electricity consumption of base case-without PV panels.

2. Electricity generated with vertical PV panels on all facades $\left(2^{\text {nd }}\right.$ floor to $20^{\text {th }}$ ) and roof (at optimum angle) on a clear summer day.

3. Electricity generated with vertical PV panels on all facades $\left(2^{\text {nd }}\right.$ floor to $20^{\text {th }}$ ) and roof (at optimum angle) on a cloudy winter day.

4. Electricity generated with vertical PV panels on all facades $\left(11^{\text {th }}\right.$ floor to $20^{\text {th }}$ ) and roof (at optimum angle) on a clear summer day.

5. Electricity generated with vertical PV panels on all facades $\left(11^{\text {th }}\right.$ floor to $20^{\text {th }}$ ) and roof (at optimum angle) on a cloudy winter day. 
Analysis of these configurations was accomplished with the calculations presented in the following section.

\subsection{Calculations}

\subsubsection{Base case electrical consumption without PV panels}

A spreadsheet, written by Professor Mahadev Raman ${ }^{1}$, was used to calculate the base case without PV panels. The input of this spreadsheet is as follows:

General building information as defined in the last section:

1. Building area based on the study model $\left(900 \mathrm{~m}^{2}\right)$

2. Building location and orientation (in the study model, the building is located in New York City, oriented to true south).

This spreadsheet calculates monthly and yearly energy consumption. Additional calculations were made to determine the hourly electrical consumption of the building. ${ }^{2}$ Hourly consumption data are needed to show the PV contribution for each configuration. Lighting ${ }^{3}$, office equipment ${ }^{4}$, HVAC, and cooling and heating energy onsumption figures were calculated on an hourly basis for the following conditions ${ }^{5}$ :

\footnotetext{
${ }^{1}$ Professor Mahadev Raman, Principal, Ove Arup \& Partners' Chairman, CTBUH Committee 12C Environmental Design, New York, NY.

${ }^{2}$ Shading was not considered for the thermal calculations of this building.

${ }^{3}$ Lighting is $18 \mathrm{~W} / \mathrm{m}^{2}$ (ASHRAE Handbook, 2007).

${ }^{4} 100 \mathrm{~W}$ per person (ASHRAE Handbook, 2007).

${ }^{5}$ When all inputs are defined, the spreadsheet calculates HVAC energy consumption and also the number of hours of cooling or heating desired for any of the occupied or unoccupied nights and days.
} 
1. Unoccupied day

2. Occupied day

3. Unoccupied night

4. Occupied night ${ }^{1}$

Day and time were determined based on sunrise and sunset hours in July. Table 4.2 shows the hourly results of a typical clear sunny day.

Table 4.2: Hourly electrical consumption on a typical clear summer day

\begin{tabular}{|c|c|}
\hline $\begin{array}{c}\text { Time } \\
\text { (hr) }\end{array}$ & $\begin{array}{c}\text { Electrical consumption } \\
(\mathrm{KWh})\end{array}$ \\
\hline 0:00 & 73.9 \\
\hline $1: 00$ & 73.9 \\
\hline 2:00 & 73.9 \\
\hline 3:00 & 73.9 \\
\hline $4: 00$ & 73.9 \\
\hline $5: 00$ & 73.9 \\
\hline 6:00 & 292.9 \\
\hline $7: 00$ & 292.9 \\
\hline 8:00 & 292.9 \\
\hline 9:00 & 1500 \\
\hline 10:00 & 1500 \\
\hline 11:00 & 1500 \\
\hline 12:00 & 1500 \\
\hline 13:00 & 1500 \\
\hline 14:00 & 1500 \\
\hline 15:00 & 1500 \\
\hline $16: 00$ & 1500 \\
\hline $17: 00$ & 1500 \\
\hline 18:00 & 292.9 \\
\hline 19:00 & 292.9 \\
\hline 20:00 & 73.9 \\
\hline 21:00 & 73.9 \\
\hline 22:00 & 73.9 \\
\hline 23:00 & 73.9 \\
\hline Total & 15.1 MWh \\
\hline
\end{tabular}

\footnotetext{
${ }^{1}$ Office hours are $8 \mathrm{am}$ to $5 \mathrm{pm}$, weekdays only; closed on Saturdays and Sundays.
} 
To determine the amount of energy consumed on a typical summer day, the results were aggregated and multiplied by working hours. The same procedure was used to obtain the electrical consumption for a typical winter day. Table 4.3 shows the results of these calculations.

Table 4.3: Hourly electrical consumption on a typical cloudy winter day

\begin{tabular}{|cc|}
\hline $\begin{array}{c}\text { Time } \\
(\text { hr })\end{array}$ & $\begin{array}{c}\text { Electrical Consumption } \\
\text { (KWh) }\end{array}$ \\
\hline $0: 00$ & 326.83 \\
\hline $1: 00$ & 326.83 \\
\hline $2: 00$ & 326.83 \\
\hline $3: 00$ & 326.83 \\
\hline $4: 00$ & 326.83 \\
\hline $5: 00$ & 326.83 \\
\hline $6: 00$ & 326.63 \\
\hline $7: 00$ & 229.8 \\
\hline $8: 00$ & 928.4 \\
\hline $9: 00$ & 928.4 \\
\hline $10: 00$ & 928.4 \\
\hline $11: 00$ & 928.4 \\
\hline $12: 00$ & 928.4 \\
\hline $14: 00$ & 928.4 \\
\hline $15: 00$ & 928.4 \\
\hline $16: 00$ & 229.8 \\
\hline $17: 00$ & 229.8 \\
\hline $18: 00$ & 326.63 \\
\hline $19: 00$ & 326.63 \\
\hline $20: 00$ & 326.63 \\
\hline $21: 00$ & 326.63 \\
\hline $22: 00$ & 326.63 \\
\hline $23: 00$ & 326.63 \\
\hline Total & 326.83 \\
\hline & $11.4($ MWh $)$ \\
\hline
\end{tabular}




\subsubsection{PV panel production}

PV panel production depends on incident radiation, which is reduced by shading and reflection and increased by reflection from adjacent buildings. It is proportional to the amount of electrical energy produced by PV panels.

\subsubsection{Incident radiation}

The amount of radiation needed to strike and be absorbed by PV panels to produce a given amount electrical energy was calculated using the Ecotect software (www.SquareOne.com, 2004). Ecotect analyzes solar radiation models by determining shading, radiation, and reflection of all the objects. By sketching the study model and entering inputs such as location, orientation, and latitude, Ecotect can calculate the amount of shading for each hour. It can also calculate the amount of reflection from adjacent buildings. Ecotect applies climatic information obtained from the energy website (www.nrel.gov, 2007). Those data are accumulated over a 10-year period. However, the data only include radiation on horizontal surfaces. Ecotect derives radiation on sloped surfaces for each orientation in the model. PV panels are located on each surface of the façade (90-degree slope) plus the roof (at a 42-degree slope). The input parameters for the Ecotect model are as follows:

1. The preliminary sketch drawn in Ecotect, with the surrounding buildings as shown in Figure 4.1

2. Location: New York City 
3. Climatic information: Derived from the www.nrel.gov website.

An excel spreadsheet was created to calculate the amount of PV production based on the incident radiation, taking into consideration other parameters that affect efficiency such as temperature. ${ }^{1}$

Equation 4.1 was used to derive PV production as follows:

\section{Equation 4.1}

$\mathrm{P}=\rho \times \mathrm{Y} \times \frac{2}{2}($ Homer, 2007)

Where:

$\mathrm{P}$ is $\mathrm{PV}$ production $(\mathrm{W})$

$\rho$ is the PV de-rating factor, a scaling factor applied to the PV array output to account for losses such as temperature, wiring mismatch, and dust effects.

$\mathrm{Y}$ is the PV panel's capacity (W) (which depends on the quantity and type of PV panels)

I is the amount of radiation in test conditions $\left(1 \mathrm{KW} / \mathrm{m}^{2}\right)$

$\mathrm{I}_{t}$ is the amount of available radiation, which takes into account shading and reflection as well as the amount of absorbed radiation on a surface $\left(\mathrm{KW} / \mathrm{m}^{2}\right)$.

Results of these calculations are presented in Section 4.6.

\footnotetext{
${ }^{1}$ Homer uses the same formula to produce simulation results.
} 


\subsubsection{PV panel production based on Homer simulations}

The next step is to design the system and enter these values into Homer to obtain the results for the chosen model configurations. Two separate runs of Homer were used to perform the overcast and sunny weather calculations. Homer takes the following inputs:

1. Electrical consumption: Homer uses hourly electrical consumption, which was calculated in the previous section.

2. Radiation: These results were compared with Homer calculation results. The Homer software was developed by NREL. ${ }^{1}$ PV system cost.

To find the PV system cost, a $1 \mathrm{KW}$ PV system was designed and its projected costs were calculated. The single-line diagram in Figure 4.4 shows all the parts needed to assemble a functional system.

\footnotetext{
${ }^{1}$ Company: National Renewable Energy Laboratory,Address:1617 Cole Boulevard, Golden, Colorado 80401,United States,Telephone:+1 (303) 384-7444,Facsimile:+1 (303) 384-7411,E-

mail:peter lilienthal@nrel.gov,Website:http://www.nrel.gov/homer
} 


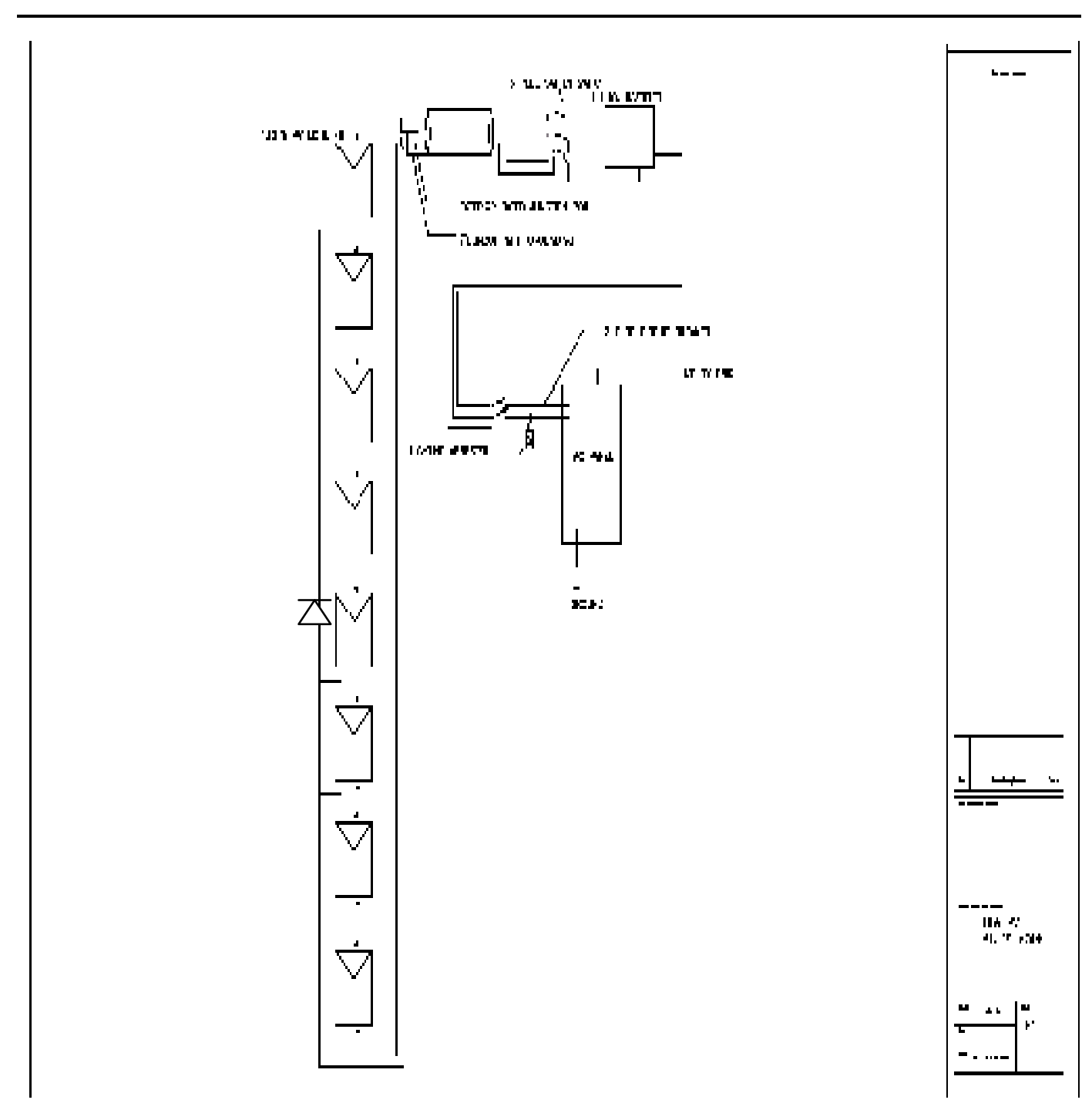

Figure 4.4: PV panel single-line diagram, 8 modules were placed in series to provide $1 \mathrm{KW}$ system.

The cost of each component is shown in Table 4.4 (www.Kyocera.com, 2007; Brooks Engineering, 2006, www.PVwatts.com, 2007; www.nrel.gov, 2007). 
Table 4.4 Cost of components in a $1 \mathrm{KW}$ crystalline PV system:

\begin{tabular}{|c|c|c|}
\hline System & Description & $\begin{array}{c}\text { Extended Price } \\
\text { (\$) }\end{array}$ \\
\hline \multicolumn{3}{|l|}{$\mathrm{PV}$} \\
\hline & Crystalline PV modules & $\$ 4,400.00^{1}$ \\
\hline & Structural element & $\$ 500.00^{2}$ \\
\hline \multicolumn{3}{|l|}{ Inverters } \\
\hline & $1.2 \mathrm{KW}$ inverter & $\$ 1,375.00$ \\
\hline & Grid-tie interface & $\$ 687.50$ \\
\hline & conduit box for inverter & $\$ 137.50$ \\
\hline \multicolumn{3}{|c|}{ Protection devices } \\
\hline & AC breaker & $\$ 22.00$ \\
\hline & Lighting arrestor & $\$ 200.00$ \\
\hline & Safety Cutoff switch & $\$ 486.75$ \\
\hline & Charge Controller & $\$ 192.50$ \\
\hline \multicolumn{3}{|c|}{ Accessories \& miscellaneous } \\
\hline & $\begin{array}{l}\text { Connectors \& terminations \&fuses \& wiring\& } \\
\text { fabrication }\end{array}$ & $\$ 350.00$ \\
\hline & Engineering & $\$ 200.00$ \\
\hline & Drafting & $\$ 180.00$ \\
\hline & Testing & $\$ 90.00$ \\
\hline & Installation & $\$ 1,600.00$ \\
\hline & Permit & $\$ 300.00$ \\
\hline & Total & $\$ 10,721.25$ \\
\hline
\end{tabular}

In Table 4.4, the first column (system) shows the type of system and the next column shows the description of the component. The following columns show the price of each component (Kyocera catalog, 2007). The accessories section (Kiss and Kart, 1996) shows the costs of all the miscellaneous items needed to build a functional system. Engineering, drafting and testing are based on $\$ 100.00$ an hour, $\$ 90.00$, and $\$ 40$ an hour, respectively (Section 4.1 assumptions). Installation takes an average of

1 (www.solarbuzz.com, 2007)

2 (Kyocera catalog, 2007) 
3-5 days (www.nrel.gov, 2007) depending on the complexity of the system with an average labor rate of $\$ 40$ per hour. The permit costs $\$ 300$ for a $1 \mathrm{KW}$ system installation (www.nrel.gov, 2007). The estimated total cost of the system is $\$ 10,721$, which equals $\$ 10.72$ per watt. However, it is claimed that systems $30 \mathrm{KW}$ and larger cost less (about $\$ 2$ per watt on average). This saving is claimed to be due to the following:

1. Identical system

2. Reducing the amount of engineering and labor

3. Creating more jobs

4. Using more experienced installers

Based on the above information, the following costs per system were assumed:

Estimated system costs per watt for a $1 \mathrm{KW}$ system with crystalline PV panels ( $\$ 4.40 /$ per watt) is $\$ 10.72$ per watt.

Consequently, for a system with greater than $30 \mathrm{KW}$ production the estimated cost per watt is: $(\$ 10.72-\$ 2)=\$ 8.72$ per watt

On the other hand, it is also been claimed that systems with thin-film PV panels (3.50 per watt) cost about $\$ 0.70$ per watt less (www.nrel.gov, 2007) ${ }^{1}$.

\footnotetext{
${ }^{1} \mathrm{~A}$ one $\mathrm{KW}$ thin-film system includes 25 modules at the cost of $\$ 3.50$ per with the capacity of 40 Watts. However, installation, mounting and transporting costs are reduced in this system because of material lightness and ease of use. 
Consequently, the estimated cost of thin-film PV panels with greater than $30 \mathrm{KW}$ production is: $(\$ 8.72-\$ 0.70)=\$ 8.02$ per watt

\subsection{Configuration results}

The results of these calculations are listed in Tables 4.5 through 4.28 for each configuration. The configurations are based on either a typical clear summer day or a typical cloudy winter day. For each configuration, energy consumption is calculated. Subsequently, the available area on the roof and facade where PV panels would be located is determined. The number of PV panels is multiplied by each PV panel's capacity. Then, the actual amount of PV panel production is calculated with consideration of the amount of available radiation, shading, temperature, mismatching, and dust accumulation effects ${ }^{1}$. Finally, the amount of PV contribution compared with the building's energy consumption is calculated for the same day. The last table in each configuration shows the Homer life cycle analysis (LCC) of the PV panels. Table 4.5 represents the cost of electricity on a typical summer day. The cost was derived by multiplying the total amount of energy consumed by the cost of energy. Section 4.1 presents the peak and off-peak costs. Equation 4.2 shows this procedure:

\section{Equation 4.2}

Cost of energy on a typical day $=$ energy consumption $\mathrm{x}$ (off-peak hours) + energy consumption $\mathrm{x}$ (peak hours)

\footnotetext{
${ }^{1}$ To obtain these results, equation 4.1 was used.
} 
Where:

Energy consumption is the amount of electricity consumed during each hour (Table 4.2). Peak hours are 7 am to $10 \mathrm{pm}$. Off-peak hours include all other times.

\subsubsection{A typical clear day in summer}

Table 4.5: Energy without PV panels

\begin{tabular}{|c|c|}
\hline $\begin{array}{c}\text { Energy without PV Panels } \\
(\mathrm{MWh})\end{array}$ & $\begin{array}{c}\text { Cost of electricity on a typical } \\
\text { summer day (\$) }\end{array}$ \\
\hline $15.1 \mathrm{MWh}$ & \multicolumn{2}{|c|}{$\$ 1,788$} \\
\hline
\end{tabular}

Table 4.6 shows the cost of the PV panels for each system. The $348 \mathrm{KW}$ system represents thin-film PV panels placed on the entire available facade. Equation 4.3 and 4.4 show the procedure used to obtain these results.

\section{Equation 4.3}

PV panels quantity $=($ available façade area $) /(\mathrm{PV}$ panels dimension $)$

Where:

Available façade area is $9300 \mathrm{~m}^{2}$

PV panels area (thin-film): Thin-film PV panels $=0.98 \mathrm{~m}^{2}$

$\mathrm{PV}$ panels area $($ crystalline $)=0.92 \mathrm{~m}^{2}$

Equation 4.4

PV size $=($ Quantity of PV panels $) \times($ PV panels wattage $)$

Where:

Quantity of PV panels (thin-film) $=9,462$ 
Quantity of PV panels (crystalline) $=10,075$

Thin Film PV panel Capacity: $40 \mathrm{~W}$ per module

Crystalline PV panel capacity: $130 \mathrm{~W}$ per module

Table 4.6: PV size (electrical capacity)

\begin{tabular}{|l|l|rr|}
\hline \multicolumn{2}{|c|}{$\begin{array}{c}\text { PV size } \\
(\mathrm{KW})\end{array}$} & \multicolumn{2}{c|}{$\begin{array}{c}\text { Cost } \\
(\$)\end{array}$} \\
\hline Thin-Film & $348 \mathrm{KW}$ & \multicolumn{2}{c|}{$\$ 2,790,960$} \\
\hline Crystalline & $1228 \mathrm{KW}$ & & $\$ 10,708,106$ \\
\hline
\end{tabular}

Table 4.7 shows the amount of PV production for floors 2 through 11 (lower floors) and 11 through 20 (upper floors). Equations 4.3 and 4.4 were used to calculate the capacity of each side. Then these results were modified based on each orientation. Equation 4.1 was used to produce these results as stated in the prior section (Section 4.1). Each column shows the amount of production based on the amount of radiation absorbed by the surface, its capacity, and a de-rating factor. The amount of radiation on each surface was calculated using Ecotect. The de-rating factor was calculated based on equation 4.7 .

\section{Equation 4.5}

$\rho(\mathrm{d}$ factor $)=0.5 \% *\left(\mathrm{t}_{1}-\mathrm{t}_{2}\right)$ Crystalline, where $\mathrm{t}_{1}$ is $25^{\circ} \mathrm{C}$, and $\mathrm{t}_{2}$ is the temperature of the location (King et al., 1997; Homer, 2007).

\section{Equation 4.6}

$\rho(\mathrm{d}$ factor $)=0.21 \% *\left(\mathrm{t}_{1}-\mathrm{t}_{2}\right)$ Thin-film, where $\mathrm{t}_{1}$ is $25^{\circ} \mathrm{C}$ and $\mathrm{t}_{2}$ is the temperature of the location (King et al., 1997; Homer, 2007).

Equation 4.7:

$\rho(\mathrm{d}$ factor $)=5 \%$ mismatching $+10 \%$ dust (PG\&E Seminar, 2007). 
Table 4.7: PV production

\begin{tabular}{|l|r|r|}
\hline \multicolumn{1}{|c|}{$\begin{array}{c}\text { PV production } \\
\text { (KWh) }\end{array}$} & $\begin{array}{c}\text { Crystalline } \\
\text { (KWh) }\end{array}$ & $\begin{array}{c}\text { Thin-Film } \\
(\mathrm{KWh})\end{array}$ \\
\hline Façade Upper Floors-East Side & 304 & 89 \\
\hline Façade Lower Floors-East Side & 284 & 84 \\
\hline Façade Upper Floors-North Side & 94 & 25 \\
\hline Façade Lower Floors-North Side & 91 & 103 \\
\hline Façade Upper Floors-West Side & 345 & 104 \\
\hline Façade lower Floors-West Side & 346 & 88 \\
\hline Façade Upper Floors-South side & 295 & 89 \\
\hline Façade Upper Floors-South side & 297 & 63 \\
\hline Roof & 211 & 669 \\
\hline Total & 2,267 & \\
\hline
\end{tabular}

Table 4.8: PV contribution

\begin{tabular}{|l|r|r|}
\hline \multicolumn{2}{|c|}{ PV contribution } & $\begin{array}{c}\text { Amount of saving of the original electricity bill } \\
\text { in one day }\end{array}$ \\
\hline Crystalline silicon & $15 \%$ & $\$ 880$ \\
\hline Thin-film & $5 \%$ & \\
\hline
\end{tabular}

To obtain the LCC results from Homer, the results were calculated and were compared with Homer results. The difference was entered as a de-rating factor in Homer ${ }^{1}$.

Table 4.8 shows the PV panel contribution for each type of PV panel. These results are based on Homer LCC analysis with the assumption discussed in Section 4.1. The first column shows the initial costs of PV panels, converters (inverters), and the grid system. As the result shows, PV panels have a very high initial cost, which is a disadvantage compared to the grid system that only charges building owners for interconnections. The next column is annualized capital costs. HOMER annualizes

\footnotetext{
${ }^{1}$ Homer does not account for shading and reflection and radiation other than data provided on the NREL website and it should be entered manually, which is really time consuming for a typical day. So in order to obtain the results from this, the calculated production results from the spreadsheet and Homer were compared and were entered as a de-rating factor in the Homer software.
} 
the initial capital of each component over the project lifetime to calculate its annualized capital cost. The cost simulation results display the annualized capital cost of each system component along with the total annualized capital cost. The annualized replacement cost of a system component is the annualized value of all the replacement costs occurring throughout the lifetime of the project, minus the salvage value at the end of the project lifetime. PV panels do not need any replacement over their 25-year lifetime. However, inverters have a lifetime of 15 years or less. Therefore, they would need a whole value replacement over a 25 -year period. The next column represents the value of operation and maintenance (O\&M) costs. The O\&M cost of a component is the annual cost of operating and maintaining it. However, the grid O\&M is the annual cost of buying electricity from the grid. O\&M costs depend on system size. In the $1228 \mathrm{KW}$ system, O\&M costs will reach $\$ 852$ (2.5 days for a $\$ 40$ per hour technician). The last column shows the total annualized costs, which total all other columns. By subtracting the total costs of the grid system with PV panels from the one without PV panels, the total amount of savings can be found.

Table 4.9: The $1228 \mathrm{KW}$ system

\begin{tabular}{|c|c|c|c|c|c|}
\hline \multirow[t]{4}{*}{ System } & $1228 \mathrm{KW}$ & & & & \\
\hline & Initial & Annualized & Annualized & Annual & Total \\
\hline & Capital & Capital & Replacement & O\&M & Annualized \\
\hline & (\$) & $(\$ / y r)$ & $(\$ / y r)$ & $(\$ / y r)$ & $(\$ / y r)$ \\
\hline Grid & 75 & 5 & 0 & 627,491 & 627,491 \\
\hline PV System & $10,708,106$ & 685,447 & 110,158 & 1,431 & 797,036 \\
\hline Grid without PV & 0 & 0 & 0 & 710,106 & 710,106 \\
\hline \multicolumn{4}{|c|}{$\begin{array}{l}\text { PV reduction in electricity cost } \\
\text { PV contribution }\end{array}$} & $\begin{array}{l}\$ 82,615 \\
17.5 \%\end{array}$ & \\
\hline
\end{tabular}


Table 4.9 and 4.10 show the simulation results with a $55 \%$ de-rating factor. However, the results differ from the one-day calculations, which only show an hourly analysis of a typical summer day. This is obtained by computing the levelized average amount of de-rating factor for each orientation.

Table 4.10: The $348 \mathrm{KW}$ system

\begin{tabular}{|c|c|c|c|c|c|}
\hline \multirow{4}{*}{ System } & \multicolumn{5}{|l|}{$348 \mathrm{KW}$} \\
\hline & Initial & Annualized & Annualized & Annual & Total \\
\hline & Capital & Capital & Replacement & O\&M & Annualized \\
\hline & (\$) & $(\$ / y r)$ & $(\$ / y r)$ & $(\$ / y r)$ & $(\$ / y r)$ \\
\hline Grid & 75 & 5 & 0 & 652,163 & 685,284 \\
\hline PV & $2,790,960$ & 178,655 & 33,736 & 692 & 213,084 \\
\hline Grid without PV & 0 & 0 & 0 & 710,106 & 710,106 \\
\hline \multicolumn{5}{|c|}{ PV reduction in electricity cost } & $\$ 24,822$ \\
\hline PV Contribution & & & & & $5 \%$ \\
\hline
\end{tabular}

\subsubsection{A typical cloudy day in winter}

Table 4.11 shows the cost of energy as stated in Section 4.6.1. In this section, the amount of energy consumption was shown in Table 4.3. This amount is about four MWh less than the clear sunny day electrical consumption.

Table 4.11: Energy without PV panels

\begin{tabular}{|c|c|}
\hline $\begin{array}{c}\text { Energy without PV Panels } \\
(\mathrm{MWh})\end{array}$ & $\begin{array}{l}\text { Cost } \\
(\$)\end{array}$ \\
\hline 11.4 & $\$ 1,294$ \\
\hline
\end{tabular}

The capacity of PV panels remains the same in both configurations as long as equations 4.4 and 4.5 are independent of the climatic conditions. 
Table 4.12: PV Size

\begin{tabular}{|l|l|rr|}
\hline \multicolumn{2}{|c|}{$\begin{array}{c}\text { PV Size } \\
(\mathrm{KW})\end{array}$} & \multicolumn{2}{c|}{$\begin{array}{c}\text { Cost } \\
(\$)\end{array}$} \\
\hline Thin-film & 348 & \multicolumn{2}{|c|}{$\$ 2,790,906.00$} \\
\hline Crystalline & 1,228 & $\$ 10,708,106.00$ \\
\hline
\end{tabular}

Amount of PV production in this configuration was calculated based on diffused radiation as the only source of radiation. The assumption was that the roof would see the full dome while façades would see the half sky dome. Results were calculated for lower and upper floors and the roof. These results are shown in Table 4.13.

Table 4.13: PV production

\begin{tabular}{|l|r|rr|}
\hline $\begin{array}{c}\text { PV production } \\
(\mathrm{KWh})\end{array}$ & $\begin{array}{c}\text { Crystalline } \\
(\mathrm{KWh})\end{array}$ & $\begin{array}{c}\text { Thin-Film } \\
(\mathrm{KWh})\end{array}$ \\
\hline Façade lower floors & 44 & 13 \\
\hline Façade upper floors & 47 & 12 \\
\hline Roof & 81 & 23 \\
\hline Total & 445 & 123 \\
\hline
\end{tabular}

Table 4.14: PV contribution

\begin{tabular}{|l|r|r|}
\hline \multicolumn{2}{|c|}{$\begin{array}{c}\text { PV contribution } \\
(\%)\end{array}$} & \multicolumn{2}{c|}{$\begin{array}{c}\text { Amount of saving of the original } \\
\text { electricity bill in one day (\$) }\end{array}$} \\
\hline Crystalline silicon & $4 \%$ & $\$ 5,451$ \\
\hline Thin-film & $1 \%$ & $\$ 1,314$ \\
\hline
\end{tabular}

Tables 4.15 and 4.16 show the LCC analysis in crystalline and thin-film PV panels, respectively. 
Table 4.15: LCC analysis for the 25-year-lifetime $1228 \mathrm{KW}$ system

\begin{tabular}{|c|c|c|c|c|c|c|}
\hline \multicolumn{7}{|c|}{$1228 \mathrm{KW}$} \\
\hline & Initial & & Annualized & Annualized & Annual & Total \\
\hline & Capital & & Capital & Replacement & $\mathrm{O} \& \mathrm{M}$ & Annualized \\
\hline & $(\$)$ & & $(\$ / y r)$ & (\$/yr) & $(\$ / y r)$ & $(\$ / y r)$ \\
\hline Grid & & 75 & 5 & 0 & 228,247 & 231,985 \\
\hline PV & $10,708,106$ & & 685,447 & 110,158 & 1,478 & 797,083 \\
\hline Grid without PV & 0 & & 0 & 0 & 235,095 & 235,095 \\
\hline \multicolumn{6}{|c|}{ PV reduction in electricity cost } & $\$ 3,110$ \\
\hline \multicolumn{4}{|l|}{ PV contribution } & & & $5 \%$ \\
\hline
\end{tabular}

Table 4.16: LCC analysis for the 25-year-lifetime $348 \mathrm{KW}$ system

\begin{tabular}{|c|c|c|c|c|c|}
\hline \multicolumn{6}{|l|}{ System 348KW } \\
\hline & Initial & Annualized & Annualized & Annual & Total \\
\hline & Capital & Capital & Replacement & O\&M & Annualized \\
\hline & $(\$)$ & $(\$ / y r)$ & $(\$ / y r)$ & $(\$ / y r)$ & $(\$ / y r)$ \\
\hline Grid & 75 & 5 & 0 & 232,769 & 234,139 \\
\hline PV & $2,790,960$ & 178,655 & 33,736 & 692 & 213,084 \\
\hline & 0 & 0 & 0 & 235,095 & 235,095 \\
\hline \multicolumn{6}{|l|}{ Grid without PV } \\
\hline \multicolumn{5}{|c|}{ PV reduction in electricity cost } & 9,404 \\
\hline \multicolumn{5}{|l|}{ PV Contribution } & $1 \%$ \\
\hline
\end{tabular}

\subsubsection{A typical sunny day in summer (upper floors)}

Table 4.17: Energy without PV panels

\begin{tabular}{|c|c|}
\hline $\begin{array}{c}\text { Energy without PV Panels } \\
\text { (MWh) }\end{array}$ & $\begin{array}{c}\text { Cost } \\
(\$)\end{array}$ \\
\hline 15.1 & $\$ 1,788.00$ \\
\hline
\end{tabular}

This configuration only shows the upper floors (11-20). Table 4.17 results were

calculated based on the same methodology used for the first configuration (complete building analysis). 
Table 4.18: PV size

\begin{tabular}{|l|l|c|}
\hline \multicolumn{2}{|c|}{$\begin{array}{c}\text { PV Size } \\
(\mathrm{KW})\end{array}$} & \multicolumn{2}{c|}{$\begin{array}{c}\text { Cost } \\
(\$)\end{array}$} \\
\hline Thin-Film & 188 & \multicolumn{2}{|c|}{$\$ 1,507,707.00$} \\
\hline Crystalline & 648 & $\$ 5,140,560.00$ \\
\hline
\end{tabular}

The results compared to the first configuration indicate that although half of the building has been used in this configuration, the amount of savings is not half but about $60 \%$ of the first configuration. This indicates that the upper floors are better candidates for PV panel placement.

Table 4.19: PV production

\begin{tabular}{|l|c|r|}
\hline \multicolumn{1}{|c|}{$\begin{array}{c}\text { PV production } \\
\text { (MWh) }\end{array}$} & $\begin{array}{c}\text { Crystalline } \\
\text { (MWh) }\end{array}$ & $\begin{array}{c}\text { Thin-Film } \\
\text { (MWh) }\end{array}$ \\
\hline Façade Upper Floors-East Side & 404 & 119 \\
\hline Façade Upper Floors-North Side & 84 & 25 \\
\hline Façade Upper Floors-West Side & 446 & 88 \\
\hline Façade Upper Floors-South side & 295 & 63 \\
\hline Roof & 211 & 429 \\
\hline Total & 144 & \\
\hline
\end{tabular}

Table 4.20: PV contribution

\begin{tabular}{|l|r|rr|}
\hline \multicolumn{2}{|c|}{$\begin{array}{c}\text { PV contribution } \\
(\%)\end{array}$} & $\begin{array}{c}\text { Amount of savings of the original electricity } \\
\text { bill in one day (\$) }\end{array}$ \\
\hline Crystalline silicon & $10 \%$ & & $\$ 178$ \\
\hline Thin-film & $3 \%$ & & $\$ 48$ \\
\hline
\end{tabular}

Table 4.21: $648 \mathrm{KW}$ system

\begin{tabular}{|c|c|c|c|c|c|}
\hline \multicolumn{6}{|l|}{ System $648 \mathrm{KW}$} \\
\hline & Initial & Annualized & Annualized & Annual & Total \\
\hline & Capital & Capital & Replacement & O\&M & Annualized \\
\hline & (\$) & $(\$ / y r)$ & $(\$ / y r)$ & $(\$ / y r)$ & $(\$ / y r)$ \\
\hline Grid & 75 & 5 & 0 & 664,420 & 664,420 \\
\hline PV & $5,140,560$ & 329,057 & 48,980 & 1,425 & 379,462 \\
\hline Grid without PV & 0 & 0 & 0 & 710,106 & 710,106 \\
\hline \multirow{2}{*}{\multicolumn{2}{|c|}{$\begin{array}{l}\text { PV reduction in electricity cost } \\
\text { PV contribution }\end{array}$}} & & & & $\$ 45,686$ \\
\hline & & & & & $9 \%$ \\
\hline
\end{tabular}


Table 4.22: $188 \mathrm{KW}$ system

\begin{tabular}{|c|c|c|c|c|c|}
\hline \multicolumn{6}{|l|}{ System $188 \mathrm{KW}$} \\
\hline & Initial & Annualized & Annualized & Annual & Total \\
\hline & Capital & Capital & Replacement & O\&M & Annualized \\
\hline & (\$) & $(\$ / y r)$ & $(\$ / y r)$ & $(\$ / y r)$ & $(\$ / y r)$ \\
\hline PV & $1,507,760$ & 96,515 & 15,147 & 388 & $1,507,760$ \\
\hline Grid & 75 & 5 & 0 & 696,822 & 696,822 \\
\hline & 0 & 0 & 0 & 710,106 & 710,106 \\
\hline \multirow{3}{*}{\multicolumn{5}{|c|}{$\begin{array}{l}\text { Grid without PV } \\
\text { PV reduction in electricity cost } \\
\text { PV contribution }\end{array}$}} & \\
\hline & & & & & $\$ 13,284$ \\
\hline & & & & & $3 \%$ \\
\hline
\end{tabular}

\subsubsection{A typical cloudy day in winter (upper floors)}

The same methodology used in configuration 2 was applied in this section to derive results. The results indicate that the amount of savings in this configuration is almost $50 \%$ of the complete building results (configuration 2).

Table 4.23: Energy without PV panels

\begin{tabular}{|c|cc|}
\hline $\begin{array}{c}\text { Energy without PV Panels } \\
(\mathrm{MWh})\end{array}$ & $\begin{array}{c}\text { Cost } \\
(\$)\end{array}$ \\
\hline $11.4 \mathrm{MWh}$ & & $\$ 1,294.00$ \\
\hline
\end{tabular}

Table 4.24: PV size

\begin{tabular}{|l|l|ll|}
\hline \multicolumn{2}{|c|}{$\begin{array}{c}\text { PV Size } \\
(\mathrm{KW})\end{array}$} & $\begin{array}{c}\text { Cost } \\
(\$)\end{array}$ \\
\hline Thin-Film & 188 & & $\$ 1,507,707.00$ \\
\hline Crystalline & 648 & & $\$ 5,140,560.00$ \\
\hline
\end{tabular}

Table 4.25: PV production

\begin{tabular}{|c|c|c|}
\hline PV production & $\begin{array}{l}\text { Crystalline } \\
\text { (KWh) }\end{array}$ & $\begin{array}{l}\text { Thin-Film } \\
\text { (KWh) }\end{array}$ \\
\hline Façade Upper Floors & 44 & 13 \\
\hline Roof & 81 & 23 \\
\hline Total & 257 & 75 \\
\hline
\end{tabular}


Table 4.26: PV contribution

\begin{tabular}{|l|r|r|}
\hline \multicolumn{2}{|c|}{$\begin{array}{c}\text { PV contribution } \\
\text { (\%) }\end{array}$} & $\begin{array}{c}\text { Amount of savings of the original electricity } \\
\text { bill in one day (\$) }\end{array}$ \\
\hline Crystalline silicon & $2.2 \%$ & \\
\hline Thin-film & $1 \%$ & \\
\hline
\end{tabular}

Table 4.27: LCC analysis

\begin{tabular}{|c|c|c|c|c|c|}
\hline \multicolumn{6}{|l|}{$188 \mathrm{KW}$ system } \\
\hline & Initial & Annualized & Annualized & Annual & Total \\
\hline & Capital & Capital & Replacement & O\&M & Annualized \\
\hline & (\$) & $(\$ / y r)$ & $(\$ / y r)$ & $(\$ / y r)$ & $(\$ / y r)$ \\
\hline Grid & 75 & 5 & 0 & 233,767 & 233,767 \\
\hline PV & $1,507,760$ & 96,515 & 15,147 & 1,478 & 113,139 \\
\hline Grid without PV & 0 & 0 & 0 & 235,095 & 235,095 \\
\hline \multirow{2}{*}{\multicolumn{5}{|c|}{ PV reduction in electricity cost }} & $\$ 2,115$ \\
\hline & & & & & $1 \%$ \\
\hline
\end{tabular}

Table 4.28: LCC analysis

\begin{tabular}{|c|c|c|c|c|c|}
\hline \multicolumn{6}{|l|}{ 648KW system } \\
\hline & Initial & Annualized & Annualized & Annual & Total \\
\hline & Capital & Capital & Replacement & O\&M & Annualized \\
\hline & (\$) & $(\$ / y r)$ & $(\$ / y r)$ & $(\$ / y r)$ & $(\$ / y r)$ \\
\hline Grid & 75 & 5 & 0 & 231,072 & 231,072 \\
\hline PV & $5,140,560$ & 329,057 & 48,980 & 1,425 & 379,462 \\
\hline Grid without PV & 0 & 0 & 0 & 235,095 & 235,095 \\
\hline \multirow{2}{*}{\multicolumn{5}{|c|}{$\begin{array}{l}\text { PV reduction in electricity cost } \\
\text { PV contribution }\end{array}$}} & $\$ 1,743$ \\
\hline & & & & & $3 \%$ \\
\hline
\end{tabular}




\subsection{Summary of results}

Costs and savings were calculated based on grid input costs (Section 4.1). The amount of energy consumed was calculated based on the breakdown of the results for energy consumed under the following conditions:

1. Unoccupied day

2. Occupied day

3. Unoccupied night

4. Occupied night

The data were obtained by comparing sunrise and sunset times (to determine day and night) and working hours ( $8 \mathrm{am}$ to $5 \mathrm{pm})$. However, the peak energy rate $(\$ 0.12 / \mathrm{kWh})$ is in effect from 7AM to 10PM each day.

Table 4.3 shows the overall PV size. This value was calculated by dividing the area of the façade by the PV panel dimensions. Each PV panel type has a unique size (Section 4.1, input parameters). These calculations incorporated the efficiency difference between crystalline and thin-film PV panels (Homer, 2007) ${ }^{1}$. Table 4.5

\footnotetext{
${ }^{1}$ The efficiency of the PV array is not an input to HOMER. That is because HOMER denominates the size of the PV array in terms of $\mathrm{KW}$ of rated capacity, not in terms of $\mathrm{m}^{2}$. The rated capacity of a PV module, which is the amount of power it produces under standard test conditions, accounts for the panel's efficiency. Two modules with the same area and different efficiencies would have different rated capacities. Therefore, by dealing with rated capacity, HOMER does not need to know the efficiency of the panel (Homer, 2007).
} 
shows PV panel production for each surface. This data is the product of incident solar radiation on the particular surface and PV panel capacity (Table 4.2) using full functionality parameters (Section $4.3^{1}$ ).

The results show that PV panels on the west and east surfaces produce more energy than those on the south (Figure 4.5 shows the variation of PV production across four different orientations (south-east-north-west). This contradicts previous research found in the literature review that claimed that southwest- and southeast-facing surfaces produce more energy. To test the validity of these unexpected results, these data were compared with the same surfaces in winter. The results show that the south surface in the winter has the highest value, while in summer, the value increases on the western and eastern sides. The conclusion is that an increased amount of reflected radiation from adjacent buildings and the fact that the north side is shaded almost all the time ${ }^{2}$. In addition, this study model assumed that all façades of adjacent buildings are either single-glazed or double-glazed or brick, so the whole building would reflect evenly on all parts of the projected wall. Normally, only windows are single or double glazed; this difference may have also contributed to these unexpected results.

\footnotetext{
${ }^{1}$ Equation 4.1

${ }^{2}$ The north side is shaded in this study model because of the layout of the buildings. A20-story brick building is located at the north side of the main building. It reflects a small amount of radiation (compared to the single-glazed and double-glazed surfaces). This building blocks most of radiation to the main study building.
} 


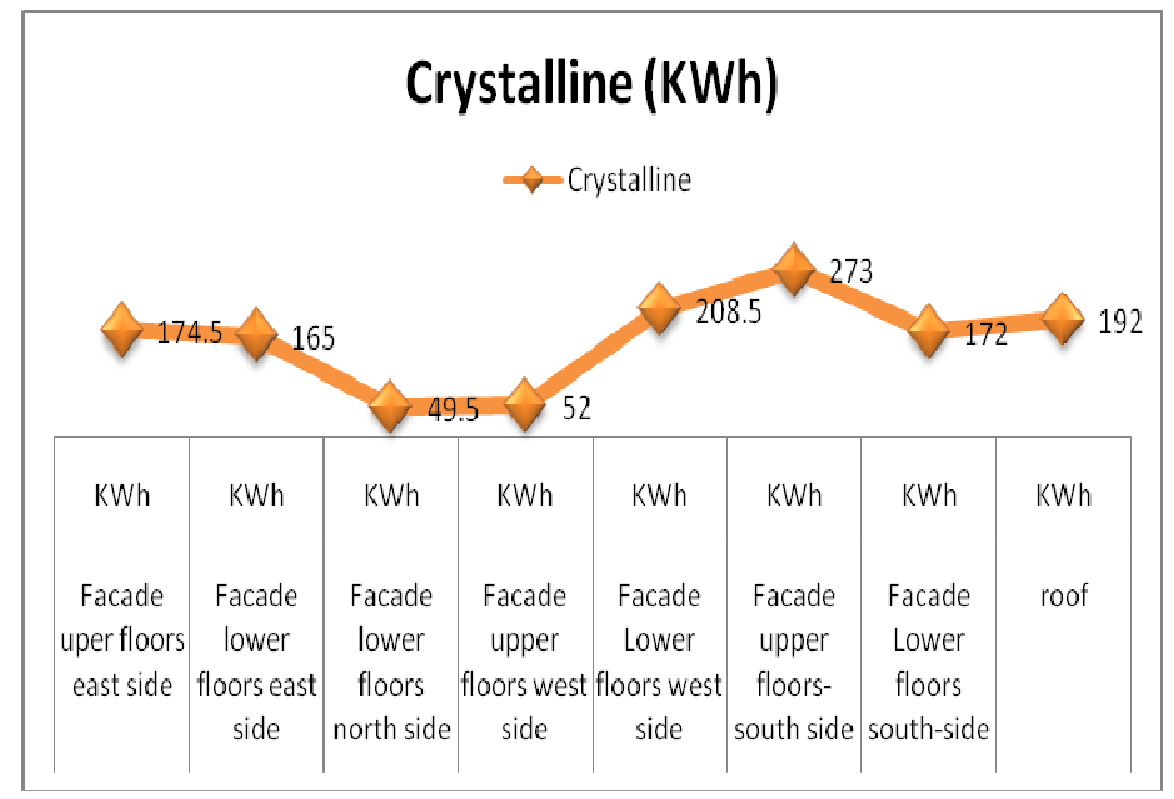

Figure 4.5 PV production variation for four different orientations (PV panels are crystalline silicon, and they were placed on floors 2 through 11 and 11 through 20).

Table 4.29: PV production

\begin{tabular}{|l|r|r|}
\hline \multicolumn{1}{|c|}{$\begin{array}{c}\text { PV production } \\
\text { (KWh) }\end{array}$} & $\begin{array}{c}\text { Crystalline } \\
(\mathrm{KWh})\end{array}$ & $\begin{array}{c}\text { Thin-Film } \\
(\mathrm{KWh})\end{array}$ \\
\hline Façade Upper Floors-East Side & 45 & 13 \\
\hline Façade Lower Floors-East Side & 46 & 21 \\
\hline Façade Upper Floors-West Side & 72 & 32 \\
\hline Façade lower Floors-West Side & 86 & 73 \\
\hline Façade Upper Floors-South side & 251 & 77 \\
\hline Façade Lower Floors-South side & 263 & \\
\hline
\end{tabular}

As shown in Table 4.29, the south façade exhibits the greatest amount of electricity production in winter, in agreement with all the references. According to these results, careful pre-planning should be performed prior to the design of PV panel installations. 


\subsubsection{Orientation}

In nearly all configurations (except the entire building on a clear, sunny day), the south side receives the greatest amount of radiation compared to other orientations. Thus, it is recommended to place the PV panels on the south side of the building.

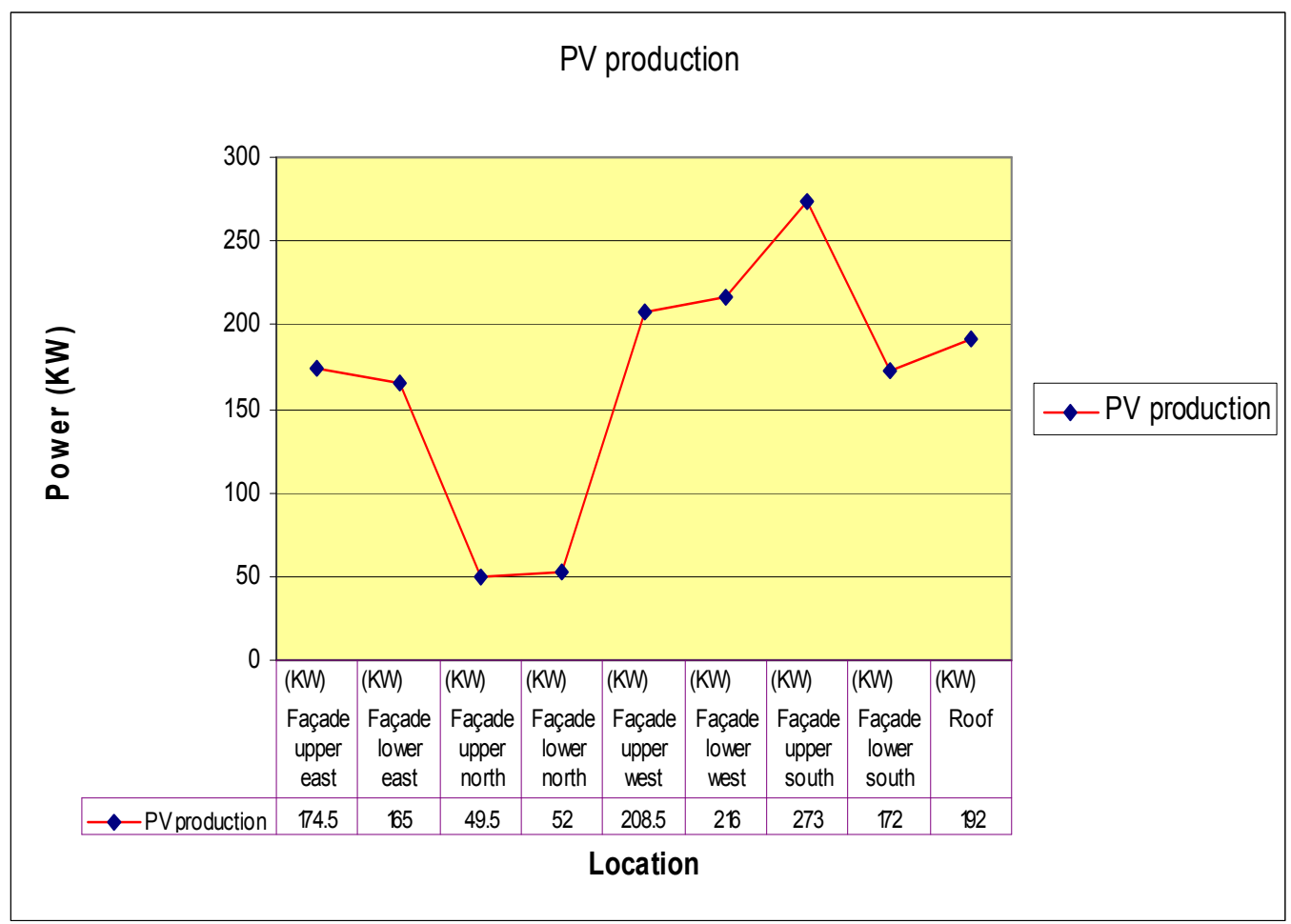

Figure 4.6 Average PV production variation for the entire building, for four orientations, on a clear day in summer and winter

Figure 4.6 shows the PV production variation for the entire building, which was calculated on a clear day in summer and winter. The results show that the south side has the highest amount of radiation, while the north side has the least. 


\subsubsection{Type}

In all of the configurations, the results match the prior discussions in the literature review section. The crystalline silicon PV type has the greatest electrical energy production on a clear summer day, while thin-film PV panels on cloudy days produce the least energy. However, as stated in the literature review section, initial costs are also higher for crystalline PV panels. The amount of PV reduction impact for each type of PV panels is shown in Figure 4.7.

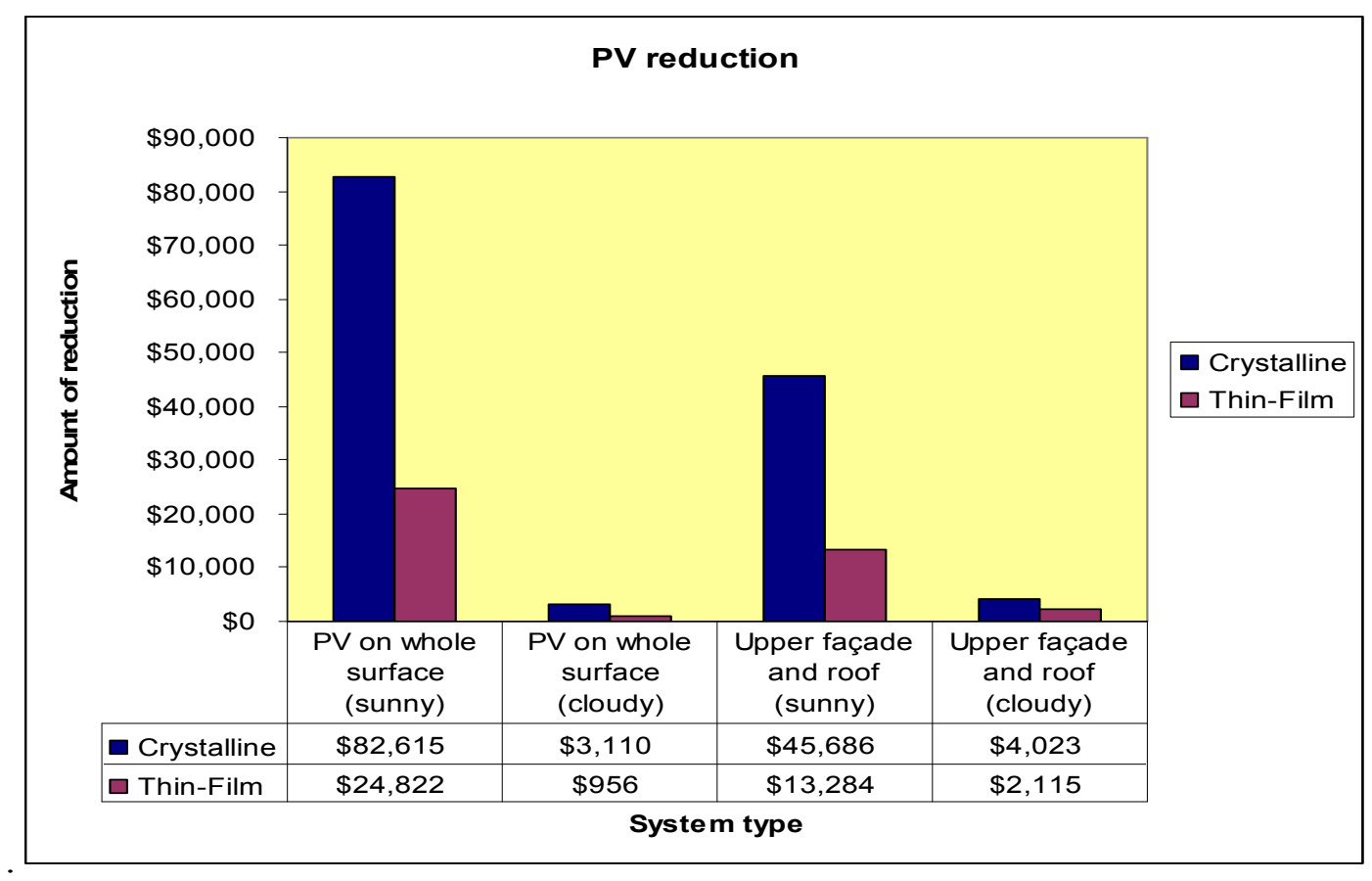

Figure 4.7: PV reduction in electricity cost

\subsubsection{Location}

In almost all configurations, the nine upper floors (11-20) produce approximately $20 \%$ more electrical energy than the 10 lower floors (2-11), with $30 \%$ less cost (accounting for PV panel capacity). These results suggest that it is not recommended 
to locate PV panels on the lower floors. This may be caused by blockage from adjacent buildings, which creates shading and consequently reduces the available incident radiation striking these floors. 


\section{Chapter 5: Conclusions, discussions, and recommendations}

Based on discussions in the last three chapters, the feasibility of PV panels in multistory buildings was assessed with respect to the following factors:

- Technical feasibility

- Economical feasibility

- Subjective (qualitative) feasibility

\subsection{Technical feasibility}

One of the fundamental steps in designing a solar system is an initial feasibility study, in which designers evaluate all the aspects of the design. This includes site evaluation, shading and radiation studies, system engineering configuration, equipment integration, and of all the issues associated with installation and system integration. Based on results from Chapter 4, it is more efficient to assess PV panels in the preliminary design stage. PV array single-line diagrams and computer-aided shading and radiation studies are necessary for PV designs. Based on the preliminary design studies of the study model in Chapter 4, several design solutions were suggested. However, these criteria, along with the intrinsic characteristics of PV panels, limit PV operational opportunities as a primary energy source in these types of buildings; therefore, they cannot satisfy the building's electrical energy needs and should be installed along with backup power (i.e., the external utility grid or other energy sources). However, it should be noted that the study model is a subjective 
model, and the results may change dramatically by changing variables that affect PV panel performance, such as shading and temperature.

The following strategies that mitigate insufficient PV energy production may be considered:

- Applying more efficient PV panels.

However, the more efficient the PV panels, the more expensive they are. There are a number of limitations in PV panel physics, which currently impose an efficiency barrier of about $30 \%$.

- Reducing the electrical needs of a multi-story building.

This option may be more plausible. The study model showed, however, that applying all kinds of energy efficient designs and PV panels at their highest production, with the whole building covered with PV panels, can only provide $15 \%$ of the total energy needs.

\subsection{Economical feasibility}

Although it is assumed that it is possible to operate PV panels anywhere solar radiation exists, in some areas it is not economically viable. The geographic region determines not only the amount of sunshine but also the cost of gridsupplied electricity. The feasibility study presented here considers the economics of engineering, material, installation costs, and the complexity of the project. Nevertheless, another variable is whether existing tax incentives are favorable to 
renewable energy sources such as PV. Yet, the very high initial costs of PV panels make them an unattractive alternative for building designers even though life-cycle analyses show some amount of saving over the whole lifetime of the PV project. An integrated building energy system is generally procured through a construction budget. Electricity generated by the BIPV power system creates savings that reduce operating budgets. However, most multi-story office buildings are leased by their occupants; the owner of the building does not necessarily occupy the building. Therefore, life cycle analyses of savings on electrical energy are a compelling factor for occupants, who pay for power consumption, but these savings do not necessarily interest building owners. Nevertheless, reduction of the initial cost of PV panels to enable fitting them into construction budgets can be accomplished in several ways.

- Reducing the cost of materials

Although costs may be reduced in the future, this factor is sensitive to internal and external markets for PV panels, and is thus not a factor that can be easily controlled. Following on the discussion in Chapter 2 and 3, the price of PV panels increased over the last two years due to increased PV panel (crystalline) use by countries in which they are popular, such as Japan and Germany. Therefore, this factor cannot be relied upon for reducing the initial cost of PV panels. 
- Reducing installation costs

Although, based on Table 4.4 results only $30 \%$ of the whole project may be specified for PV panel installation, this may be a more feasible solution. A prototype system may be installed prior to a large-scale installation. Working on a prototype first may increase the efficiency of installers and field crews and help them to estimate the scope of work, allowing them to finish the job in a timely manner with less risk of faulty installation. This approach can allow in-house designers to simply follow the standards of the existing prototype to increase the efficiency of their work designing PV panels. Such effects have been observed in the past several years; the installation costs of PV panels have declined substantially over the past a few years. In 2005 the cost of installing a $1 \mathrm{KW}$ PV system was $\$ 13$ per Watt; however, this cost was reduced in the year of 2005 to $\$ 8$ per Watt (www.nrel.gov , 2007).

- Applying governmental and institutional incentives

Tax incentives, low interest loans, and rebates can be helpful in reducing initial costs. However, based on the current New York incentives program, commercial PV panel installations are not included in net metering (except for residential buildings and power plants). Commercially installed PV panels less than $5 \mathrm{KW}$ are eligible for rebate, but systems with more than 50 KW capacities are not rebated. Consequently, crystalline PV panels are generally not used in these configurations. That may be one of the reasons 
why Four Times Square building has only a $10 \mathrm{KW}$ capacity PV panel system.

Furthermore, window-based PV panels are not off-the-shelf products at this time and must be custom fabricated for each project. This requires more lead time for PV panel delivery to the job-site. Pre-planning should allow sufficient time for PV panel delivery. On the other hand, where users reside affects their power costs, which in turn affects whether other power options such as PV might be economical. Without tax incentives and government assistance in these types of programs, PV panels are not yet economically feasible for multi-story building in the 10 to 20 stories range. PV panels are a relatively new source of energy, so there are not enough examples available. Furthermore, their high initial cost has inhibited building owners and designers from applying them in tall commercial buildings in the U.S. The high cost of energy and limited resources are the main reasons to apply various types of alternative energy. The urgency of this issue has not been demonstrated economically at this time at current energy costs. Therefore, PV panels in large multi-story buildings are not economically feasible for building owners and designers. Moreover, they cannot be considered the primary source of energy in tall buildings because they can supply only a small fraction of the electricity consumed by the building. 


\subsection{Subjective (qualitative) feasibility}

There is a qualitative measure of PV deployments in commercial multi-story buildings. In addition to benefits such as offsetting the cost of building elements, peak shaving load, providing tax credits, and multifunctional applications ${ }^{1}$, PV applications in these types of buildings present some qualitative benefits. These benefits are subjective and may be associated with public relations, a positive image, and the demonstration of a product or a positive impact on the built environment. Thus, although these factors may not be considered in an LCC analysis, they affect the decision making of the multi-story building owner. Owners of commercial multistory buildings may be large corporations, environmental friendly product manufacturers, or owner-investors ${ }^{2}$. The following are some of the qualitative, conceptual benefits of PV in commercial, multi-story buildings:

- Educational benefits

A BIPV system may have educational benefits. Technology demonstration provides education that corresponds with some agency's mission. If education is the main purpose of the system, it is the deciding factor in applying this technology. The economics of the system performance become secondary. Cost justification, therefore, is not necessarily a requirement when

\footnotetext{
${ }^{1}$ Literature review section.

${ }^{2}$ They represent those types of owners that would purchase and develop a property to lease or rent it. They are mostly interested in lower maintenance for return on their investments. Tax incentives and government support may affect their decision considerably as well. This was true for the Four Times Square building owner.
} 
a technology is used for demonstration purposes and to show the feasibility of a PV system (www.nrel.gov, 2007).

- Promotional benefits

Installations of PV systems in some large cooperation are to enhance the public relations of a company. A BIPV installation at an environmentally conscious company could be used as part of a promotional campaign. The value of the installation is identified as a benefit to the company's public relations (www.nrel.gov, 2007).

- The Enhanced leasing value of office space

The environmentally friendly aspect of this building technology can be used as a marketing tool for leasing office space. This fact was true for Four Times Square despite the high price and special guidelines for tenants to use the space. The building was almost completely leased immediately upon completion (NYSYD, 2001). One of the most renowned publications, Conde Nast, leased the office. The avoided lost rent in dollar value could be incorporated into the LCC analysis, provided the impact of the BIPV system on the probability of renting the space can be quantified.

- Business-line promotion

By designing a new building to present product strengths in architectural glazing systems and integrating custom-made BIPV modules, the building 
owners can open up new possibilities in the marketplace. This was true in many cases, including the Kyocera and Sharp Cooperation building. Following on discussions from Chapter 2, building owners and designers like to ensure product feasibility for products used in a building prior to utilizing them (www.nrel.gov, 2007).

\subsection{Further study}

- In this thesis, PV panels were not tilted in façade areas. Further study can determine the most efficient orientation of PV panels. For example, they can also be located on sunshades at an optimum tilt angle.

- It was assumed that adjacent buildings are all covered with only one material type, and that assumption might affect the results. Further study can evaluate the effect of other surface materials on adjacent buildings.

- The study model proposed in this thesis was created to optimize design solutions only. However, it was not used to evaluate PV panel efficiency and PV operational performance characteristics. Further studies may be based on monitoring the installed model to verify the real life functionality of PV panels. 
- This model was created as a pre-planning tool. Grants, tax incentives, and rebates are not incorporated into it. Further research could calculate the amount of governmental and institutional assistance that might be available. 


\section{Bibliography}

Architecture HKU (2007); Retrieved from Hong Kong Architecture University Website: http://www.arch.hku.hk/

ASHRAE Handbook (2007); ASHRAE Standards, Retrieved from http://www.ashrae.org

Budiman S. (1988); "Passively Cooled Housing Design In A Hot Humid Climate”. Master's Thesis, California Polytechnic State University of San Luis Obispo.

Cholakkal L. (2006); Cost-benefit analysis of a Building Integrated Photovoltaic Roofing; Retrieved from NREL home page: http://www.nrel.gov/

Eiffert P. and Kiss G.J. (2000); “Building Integrated Photovoltaic Design”, a source book for Architects. NREL,BK-520-25272 .

Eiffert P. and Thomson A. (2000); "U.S. Guidelines for the Economic Analysis of Building-Integrated Photovoltaic Power Systems”; NREL/TP-710-25266.

Energy star (2007); Retrieved from http://www.energystar.gov

Fanney A.H., Dourothy B.P. and Davis M. (2001); “ Measured Performance of Building Integrated Photvoltaic Panels, "; National Institute of Standards and Technology, ASME Journal of Solar Energy Engineering Vol.123, pp 187-193.

Farrel A. (2000); "New York Green Buildings". New York: Committe on Ways and Means., New York (State). Legislature, Committee on Finance; New York (State), Legislature, 278. LEG 870.8-2 1/24/2001 201-542.

Gevorkian P. (2006); Sustainable Energy Systems in Engineering (5th ed.). Boston: McGraw-Hill.

Global website. (2007). Retrieved from Kycoera cooperation website: http://www.Kyocera.com

Gregg A., Parker T. and Swenson R. (2003); "A Real World Examination of PV System Design and Performance”, United Solar Ovonic LLC, Auburn Hills, Michigan 48326, and 2. SolarQuest ® Santa Cruz, CA.

Hill B., Levinski O. and Watmuff J. (2006); "Experimental investigation of Renewable Energy for a Sustainable Future". Oxford Text Archive. 
Holusha R. (1997); “Technology in the Front Seat at 4 Times Square”; New York Times, vol:146 iss:50747 pg:7

Homer software (2007), "Analysis of Micro Power System Options", retrieved and downloaded from website: https://analysis.nrel.gov/homer/

King D.L., Kratochvil, J.A. and Boyson W.E. (1997); “Temperature Coefficients for PV Modules and Arrays: Measurementmethods, Difficulties, and Results". Photovoltaic Specialists Conference, Conference Record of the Twenty-Sixth IEEE.

Kiss G. and Kinkead J. (1995); "Optimal Building Integrated Application", NREL,TP-472-20339, 5-92.

Lechner. N. (2001);"Heating, Cooling, Lighting, Design Methods for Architects", New York: Wiley ( $2^{\text {nd }}$ edition).

Marsh, D.A. (2007); Co-Fouder and Head of Research \& Development at Square One. Isle of Man, United Kingdom. Retrived from http://www.squareone.com

Masters M.G. (2004); “Renewable and Efficient Electric Power System,. Wiley \& Sons, New York, 654 pp.

Messenger R.A. (2004); "Photovoltaic System Engineering”, London, New York, Washington: CRC.

NREL (2007); Retrieved from http://www.nrel.gov/downloads/TMY2 Solar_Data.zip

Olesen B.W. (2000), "New developments in international standards for the indoor thermal environment” Proc. of Healthy Buildings, Helsinki, Volume. 1, pp. 641-646

PG\&E Online Classes. (2007), "Understanding efficiency factor for Photovoltaic $(P V)$ Systems", Retrieved from the website:

http://www.pge.com/stocktonclasses/index.jsp\#classresults, Solar section, Wed, Jul 8, 9:00 am - 4:30 pm

PV database (2007); Retrieved from http://www.pvdatabase.org

PV Panel Performance (April, 2006); $P G$ \& E Seminar 9AM-4:30PM ,San Francisco, CA, USA: PG \& E, Spring Energy Efficency Classes.

PVWatts, (2007); Retrieved from http://www.pvwatts.com

Raman M. (2001); “Aspects of Energy Consumption In Tall Buildings”, New York, NY, Ove Arup \& Partners Engineers. 
Randell J.F. (2006); “Designing Indoor Solar Products”, New York: Wiley \& Sons Ltd.

Reygadas F., Rajagopal D., Stauth J. and Shah.N. (2000); "Photovoltaics for SelfContained TIER Wireless Node", ErC226.

San Diego Regional Renewable Energy Study Group (2005, August); "Solar Photvoltaic Electric”, San Diego, California.

Sheets S.G. (1982); "A Solar High-Rise Structure”, Master's Thesis, California Polytechnic State University, San Luis Obispo.

Silvestre S. and Castaner L. (2002); “Modeling Photovoltaic Systems Using Pspice”, New York: Wiley \& Sons Ltd.

Solomon B.N. (2007); "Photvoltaics Technology Comes of Age"; Green Source, the Magazine of Sustainable Design, McGraw-Hill Construction.

Statistical Abstract of US, (2003), retrieved from the website: http://www.census.gov/prod/www/statistical-abstract-04.html

Thah M.F. (2003); “Grid Connected Photovoltaic System”, Master Thesis, Department of Engineering, University of Queensland, ST Lucia, Queensland, Australia.

Thomas R. and Fordham M. (2001). "Photovoltaics And Architecture: An Introduction for Architects and Engineers", Taylor \& Francis Publication, London: Spon Press.

US Departmant of Energy, T. G. (2005, 12 28); Retrieved from US Departmant of Energy; EERE Home: http://www.eere.energy.gov/

Witkop F.K. and Hien W. and Hess W. (2004); "Potential Of BIPV In Existing Urban High-Rise Housing in Singapore"; University of NUS, Department of Architecture.Retrived from website: http://www.arch.nus.edu.sg/akiskw. 